\title{
The Treatment of Confidential Information by the Federal Trade Commission: Pretrial Practices
}

\author{
Ernest Gellhorn†
}

An examination of the Federal Trade Commission's treatment of confidential information at the hearing level suggested that the Commission needs to reconsider the bases, objectives, and implementation of its confidentiality policies. ${ }^{1}$ This article continues that examination of Commission handling of sensitive data at a different and earlier stage of its proceedings. Attention is focused on FTC practices prior to the hearing of adjudicated matters. That is, what are and should be FTC confidentiality policies at the investigative and post-complaint discovery stage?

The Commission has devoted inordinate attention to its rules of practice in recent years. The numerous rule revisions it has made include major changes within a one year period. ${ }^{2}$ Despite, or perhaps

† Associate Professor of Law, Duke University.

The assistance of James Alexander, now a third year student at the Duke University School of Law, and the support of the Duke Endowment in the preparation of this article are gratefully acknowledged.

1 See Gellhorn, The Treatment of Confidential Information by the Federal Trade Commission: The Hearing, 116 U. PA. L. REv. 401, 433 (1968) [hereinafter cited as Gellhorn].

2 Five changes have been made in the past seven years. The first occurred in July 1961 when, in addition to the continuous hearing rule, the FTC broadened the scope of discovery. It also made interlocutory appeals from a hearing examiner's procedural rulings and appeals from an examiner's initial decision discretionary. The next change, in May 1962, concentrated on streamlining the Commission's rule-making procedures. Then, in August 1963, the FTC deleted the "good cause" requirement from its discovery provisions and provided that a deposition should be authorized when it is shown that it will "constitute or contain" relevant "evidence" and would not impose an unreasonable burden on the other party or unduly delay the proceedings; appeal procedures were turned around again and FTC review now became a matter of right when requested. See Mezines \& Parker, Discovery Before the Federal Trade Commission, 18 AD. L. REv., Winter-Spring, 55, 57 n.8, 61 n.23 (1966); Auerbach, Scope of Authority of Federal Administrative Agencies to Delegate Decision Making to Hearing Examiners, 48 MrN. L. REv. 823, 833-4 (1964). Partially in response to the passage of the Freedom of Information Act, 5 U.S.C. \& 552 (Supp. III, 1968), the Commission rewrote its rules in July 1967, this time providing that a deposition should be authorized when it is shown that it is "necessary for purposes of discovery" and that the same information could not be acquired voluntarily. FTC Procedures \& Rules of Practice, 16 C.F.R. $\$ 3.33$ (1968), as amended, 33 Fed. Reg. 7032 (1968) [hereinafter cited as FTC Rules]. The most recent changes in May 1968 empowered hearing examiners to 
because of, these constant shifts in the Commission's position on discovery and confidential treatment, the FTC's current rules neither eliminate all doubts regarding the Commission's support of the principle of open discovery nor spell out specific standards for determining whether information is sensitive and requires confidential treatment at the pretrial stage. ${ }^{3}$ On the other hand, the FTC's adoption several years ago of the long-time judicial rule of continuous trials converted basic questions of pretrial discovery from routine determinations of administrative discretion into inquiries concerning the demands of fairness. ${ }^{4}$

At the same time, courts have expanded requirements of fairness in accusatory proceedings while confirming the broad scope of agency discretion in treating confidential information..$^{5}$ Although once disputed, it now is a truism that administrative proceedings, at whatever stage, must meet constitutional standards of that process which is "due" in light of the circumstances and interests involved. ${ }^{6}$ Due process neither demands the best possible procedure nor excuses less than the best. Rather it sets the procedural Plimsoll line, and the function of judicial intervention in agency procedures is to draw the current mark and measure agency process against it. But a critical analysis of agency procedures need not and should not be so limited. The best possible procedure for insuring fair play without impeding performance of agency functions is the standard against which practices will be measured here.

rule on requests for confidential information instead of requiring certification of that question to the full Commission. FTC Rules § 3.36(c).

3 Compare Kintner, Recent Changes in Federal Trade Commission Discovery Practice, 37 ANTIrRust L.J. 238 (1968), with Stewart \& Ward, FTC Discovery: Depositions, The Freedom of Information Act and Confidential Informants, 37 ANTITRUst L.J. 248 (1968).

4 E.g., Topps Chewing Gum, Inc., FTC Dkt. No. 8463 [1963-1965 Transfer Binder] TRADE REG. REP. I 16,471 (1963); L. G. Balfour \& Co., FTC Dkt. No. 8435 [1961-1963 Transfer Binder] TRADE REg. REP. \ 16,423 (1963); see FTC Rules § 3.41(b) (authorizing hearing examiners "to order brief intervals of the sort normally involved in judicial proceedings"); Universe Chemicals, Inc., FTC Dkt. No. 8752, 3 TRADE REG. REP. 19 18,253, 18,310 (1968).

- See, e.g., Gellhorn 428-33 (application of Jencks v. United States, 353 U.S. 657 (1957), to administrative agency hearings); Miller v. Pate, 386 U.S. I (1967); FCC v. Schreiber, 381 U.S. 279 (1965).

( E.g., Joint Anti-Fascist Refugee Committee v. McGrath, 341 U.S. 123, 161-3 (1951) (Frankfurter, J., concurring); FCG v. Pottsville Broadcasting Co., 309 U.S. 134, 143-4 (1940); see Byse, The University and Due Process: A Somewhat Different View, 54 A.A.U.P. Buld. 143, 144-5 (1968). Of course, minimum procedural requirements in other contexts are not automatically applicable to administrative agency proceedings. But they should be rejected only when distinguishable on significant grounds. Similarly, procedural minima elsewhere may not satisfy due process in administrative procedure. See 1 K. C. Davis, Administrative LAW TrEatise \$\$ 8.01-.03 (1958). See also Sperry \& Futchinson Co. v. FTC, 256 F. Supp. 136, 142 (S.D.N.Y. 1966). 
As might be expected, the questions asked to determine what constitutes confidential information deserving protection at the pretrial stage do not vary significantly from those examined in treating sensitive data at the hearing level. However, the policies supporting "public hearings" are seldom present in the pretrial stage and generally should not govern disclosure requirements during investigations or discovery. For these purposes, public disclosure is unnecessary. Investigation and discovery are in no way adjudicative; they are designed to apprise the prosecutor and defendant of all available information, to eliminate needless issues, and to facilitate preparation and presentation of their cases. On the other hand, public disclosure goes to the essence of a fair hearing and is indispensable in adjudicative proceedings. The results, though seldom the rationale, of many FTC cases recognize this distinction.

A confused and confusing variable standard has been the result. Complete disclosure to the FTC, subject to uncertain future protection, appears to be the rule of nonpublic precomplaint investigations; "integrity" of agency files is the byline of secret treatment; "necessity" or "unavailability," on the other hand, may determine whether a discovery request is granted.

This article gathers FTC decisions governing confidential information at the pretrial stage ${ }^{7}$ and systematically analyzes the various approaches adopted by the Commission. Exposure of FTC confidentiality policies on a functional basis should contribute to clarification; explicit recognition of the rationale of these policies hopefully will have a self-leveling effect. In addition, this article seeks to identify the relevant interests and to suggest standards where current criteria for deciding whether sensitive information should be disclosed appear to be inadequate. Finally, standards for determining whether information warrants confidential treatment during discovery are suggested and methods of protecting such data are explored.

\section{INVESTIGATIONS}

FTC investigations are of two types: informative and regulatory. That is, they are designed either to gather information about an industry or part of the economy as a basis for formulating rules, proposing legislation, or making policy judgments, or to collect evidence

7 The focus of this article is on FTC activities which point to possible prosecutions. For example, regulatory rather than informative investigations will be examined-although some of the latter's lessons are relevant, and the principles applicable to pretrial practices often have broader applications. 
about specific companies in preparation for an FTG complaint. ${ }^{8}$ Pretrial investigations examined here involve the latter.

A creature of congressional afterthought, sharply restricted by the courts in the Commission's early years, still used primarily at the call of private complainants, the FTC's investigative powers are an indispensable weapon in the FTC's enforcement arsenal. Although authorized by Congress primarily for the purpose of conducting broad economic inquiries, ${ }^{9}$ the Commission uses its investigative powers most frequently for precomplaint preparation. ${ }^{10}$ Investigations usually are initiated because of complaints to the Commission by an investigated party's competitors, customers, or suppliers rather than as part of a preplanned enforcement scheme. ${ }^{11}$ But because the continuous hearing requirement for FTC adjudicative trials necessitates that complaint counsel prepare the essentials of his case before a complaint is issued, ${ }^{12}$ the pretrial investigation is the most significant link in the enforcement chain.

Investigations are usually accomplished voluntarily and without reliance on compulsory process. All investigations are based upon author-

8 FTC investigations are of two main types: (1) so-called general investigations of conditions and practices in certain industries or segments of the economy; and (2) pre-complaint investigations to determine whether particular companies are violating any of the statutes administered by the Commission. A general investigation, although perhaps it may lead to litigation ultimately, ends with the filing of a report organizing and analyzing the information collected; a pre-complaint investigation ends with a determination of whether or not litigation should be commenced.

Pollock, Pre-Complaint Investigations by the Federal Trade Commission, 9 ANTITRust BuLL. 1, 2 (1964); see also Withrow, Investigatory Powers of the Federal Trade CommissionConstitutional and Statutory Limitations, 24 FED. B.J. 456, 457-8 (1964); Note, Investigatory Powers of the Federal Trade Commission, 53 Nw. U.L. REv. 109 (1958).

9 See, e.g., H.R. REp. No. 533, 63d Cong., 2d Sess., pt. 1, at 3-4 (1914); T. Blalsdell, The FEDERAL TRAde Commission 107-20 (1932); Rublee, The Original Plan and Early History of the Federal Trade Commission, 11 Academy of Polrtical Sclence Procerdings 666, 671-2 (1926); Handler, The Constitutionality of Investigations by the Federal Trade Commission, 28 Colum. L. REv. 708, 720-I (1928); Boyle, Economic Reports and the Federal Trade Commission: 50 Years' Experience, 24 FED. B.J. 489 (1964).

101961 FTC Ann. Rep. 24-26; see I966 FTG Ann. Rep. 2-4; Williams, Investigations by the Federal Trade Commission, 29 ABA ANTrraust Section 71 (1965).

11 See Florida Citrus Mutual, 50 F.T.C. 959, 961 (1954); Williams, supra note 10; Auerbach, The Federal Trade Commission: Internal Organization and Procedure, 48 MrNN. L. REv. 383, 393-6 (1964). The resulting lack of agency direction has been a subject of constant criticism. E.g., H.R. REP. No. 3236, 81st Cong., 2d Sess. 16-17 (1951); Gimbel Bros., 60 F.T.C. 359, 375 (1962) (dissenting opinion); Loughlin, Investigation and Trial of Robinson-Patman Act Cases Before the Federal Trade Commission, 4 ANtrTrust BuLI. 741, 754 (1959).

12 See Marlo Furniture Co., FTC Dkt. No. 8745, 3 Trade Reg. Rep. $\mid$ 18,268 (1968); All-State Indus., Inc., FTC Dkt. No. 8738, 3 Trade Reg. ReP. I 18,103 (1967); Creel, PreTrial Discovery and Motions, 14 ABA AnrmRust Section 23 (1959); Auerbach, supra note 11 , at $425,428-9$. 
ity granted by sections 6,9 and 10 of the FTC Act, ${ }^{13}$ empowering the Commission to ( 1 ) direct a corporation to file annual or special reports and answer specific questions in writing; (2) obtain access to corporate files for examining and copying of their contents; and (3) subpoena the attendance of witnesses and the production of documentary evidence. These investigatory powers are enforceable by court order (any violation being punishable as contempt) or by judicially imposed penal sanctions.

Most pretrial investigations are conducted in private, so the issue of public disclosure is postponed. Nevertheless, questions of confidentiality occur frequently at several stages of the investigation process. The Commission may seek sensitive information from private sources or other government departments.

The primary purpose in conducting investigations is to develop evidence to support a subsequent Commission prosecution in a public hearing, and, with minor exceptions, the information is available to complaint counsel..$^{14}$ Fearful of possible disclosure, holders of sensitive data demand ironclad guarantees of appropriate safeguards. But, although the FTC's power to demand information is frequently challenged and assurances of confidential treatment are often sought, such challenges seldom succeed and promises of confidentiality are infrequently given.

\section{Public Investigations}

The most noteworthy aspect of public pretrial investigations today is their rarity and seeming insignificance. Nevertheless, the mere prospect of public precomplaint investigations raises significant questions of confidential treatment, the resolution of which contrasts sharply with the handling of sensitive data at the hearing level.

While economic inquiries and rulemaking hearings often are public, precomplaint proceedings normally take place in secrecy comparable to that of the grand jury room. Although Congress neither authorized

1315 U.S.C. $\$ \S 46,49,50$ (1964). See generally Withrow, stpra note 8; Hill, Investigative Powers and Techniques of the Federal Trade Commission, 31 J. BAR Ass'N D.C. 193 (1964); Mueller, Access to Corporate Papers Under the FTC Act, 11 KAN. L. REv. 77 (1962).

FTC investigation procedures vary. They range from fulldress formal hearings before the entire Commission, see note 17 infra and accompanying text, or an examiner, to informal inquiries by one FTC attorney-investigator seeking voluntary information without any suggestion of compulsory process. Between these extremes lie most investigations which usually are an admixture of compulsory process and cooperation between Commission counsel and respondent's attorney. See Pollock, supra note 8, at 10-25.

14 See Mississippi River Fuel Corp., FTC Dkt. No. 8657 [1965-1967 Transfer Binder] TRADE REg. REP. I 17,321 (1965); Dixon, Recent Changes in Organization and Procedure of the Federal Trade Commission, 19 ABA ANTrrrusr Section 252, 253-4 (1961). 
nor prohibited public investigations, two of the three investigative tools which it furnished the FTC with do not invite public use. Requests by the Commission for special reports from a corporation ${ }^{15}$ or for access to corporate files ${ }^{16}$ do not suggest that the requested information will be disseminated widely; only the subpoenaed witness/ document procedure follows the pattern of the typical public trial.

For almost fifty years the FTC conducted all pretrial investigations in private. Then, in late 1961, over the objection of one of its members, the full Commission held a public investigational hearing to determine whether a paper company might have violated section 7 of the Clayton Act in making several acquisitions. ${ }^{17}$ Six officials of the paper company appeared as directed, but the Commission's reliance on a public hearing was extremely controversial and the results were inconclusive.

A second public investigational hearing was held before a staff attorney-examiner in March 1962 to examine pricing practices of several grocery chains and local supermarkets for possible RobinsonPatman Act violations during a price war in Indianapolis. Here, the refusal by one firm to participate, after denial by the Commission of its motion for either nonpublic hearing or full representation by counsel,18 was upheld by a district court because of the inadequate

15 Until the Supreme Court's famous dictum in United States v. Morton Salt Co., 338 U.S. $632,652(1950)$, which suggested the broad inquisitorial field opened by $\S 6(\mathrm{~b})$, the FTC's use of special reports had been limited to general economic inquiries. E.g., FTC v. Claire Furnace Co., 274 U.S. 160 (1927); FTC v. Millers' Nat'l Fed'n, 47 F.2d 428 (D.C. Cir. 1931); FTC v. Maynard Coal Co., 22 F.2d 873 (D.C. Cir. 1927). Special reports were first used in a precomplaint investigation less than ten years ago. The use of $\S 6(\mathrm{~b})$ reports, however, has not proven an unqualified success since framing questions that will elicit desired information requires careful drafting and considerable knowledge of the industry involved. See United States v. St. Regis Paper Co., 181 F. Supp. 862 (S.D.N.Y.), aff'd and rev'd in part, 285 F.2d 607 (2d Cir. 1960), aff'd on other grounds, 368 U.S. 208 (1961).

16 Although intended originally as the Commission's most potent investigative weapon, early restrictive interpretations, e.g., FTC v. American Tobacco Co., 264 U.S. 298 (1924), even though subsequently overturned [at least sub silentio, see, e.g., $1 \mathrm{~K}$. C. DAvis, AdmiNISTRATIVE LAw TrEATISE $\$ 3.06$ (1958)], have resulted in sparing use of the FTC's visitation powers. Pollock, supra note 8 , at 12-14. Moreover, to the extent that the Commission still is required to particularize its requests, the right of visitation is, in effect, coextensive with the subpoena power. And this right of access (as with $\S 6(\mathrm{~b})$ special reports) is enforceable only by the Attorney General. I5 U.S.C. $\$ 50$ (1964). On the other hand, until a recent challenge, FTC investigative subpoenas were enforceable by the FTC directly in the district court. See FTC v. Tuttle, 244 F.2d 605 (2d Cir. 1957); FTG v. Continental Can Co., 267 F. Supp. 713 (S.D.N.Y. 1967); FTC v. Green, 252 F. Supp. 153 (S.D.N.Y. 1966). But see FTC v. Guignon, 5 Trade REg. ReP. (1968 Trade Cas.) ๆ 72,362 (8th Cir. 1968), affg 261 F. Supp. 215 (D. Mo. 1966).

17 St. Regis Paper Co., FTC File No. 551 0696, reported in BNA ANTTTRUST \& TRADE REc. REP. No. 25, A.9 (Jan. 2, 1962); id. No. 34, A-10 (March 6, 1962). Commissioner Elman was the objecting member.

18 See FTC Release (Feb. 28, 1962), reported in 3 Trade REg. REP. I 10,114.10 (1968); BNA ANtrtrust \& Trade Reg. Rep. No. 34, A-10 (March 6, 1962); id. No. 36, A-19 (March 20, 1962). 
representation permitted respondent. ${ }^{19}$ Four months later, a similar ruling thwarted an attempt by the Commission to hold a public hearing concerning Denver's milk-price wars. ${ }^{20}$ Since these ill-fated experiments, all FTC pretrial investigations have been nonpublic.

Perhaps the Commission never will attempt another public precomplaint investigation since its earlier attempts not only were generally unsuccessful, but also were severely criticized, and divided the Commission. On the other hand, with the 1963 adoption of the socalled Mead rules, ${ }^{21}$ the FTC expanded the scope of legal representation permitted in public (and nonpublic) investigations, possibly removing this procedural impediment. ${ }^{22}$ Moreover, since the FTC's rules continue to assert the power to hold such hearings, ${ }^{23}$ the questions of confidentiality they raise cannot safely be ignored.

The Commission has apparently taken the position that the dearth of public precomplaint investigations excuses it from providing any guidance as to how confidential material will be judged and treated in public investigations. ${ }^{24}$ Its decisions and rules are silent. A cursory glance might suggest that the questions of confidential treatment at public trials and pretrial investigations are identical and that rules for adjudicative proceedings should apply to both. But closer analysis suggests that each is distinctive, that confidential treatment should be granted readily in public investigations in contrast to public trials, and, perhaps, that fairness (if not due process) requires all precomplaint investigations to be private.

Sensitive data is protected by in camera treatment in adjudicative hearings only when the proponent of confidential treatment demonstrates that public disclosure would result in "clearly defined, serious

19 Hall v. Lemke, 1962 Trade Cas. If 70,338 (N.D. Ill. 1962).

20 Archer v. Lemke, 1962 Trade Cas. If 70,417 (N.D. Ill. 1962). This proposed hearing arguably was informational rather than regulatory. See Note, The Distinction Between Informing and Prosecutional Investigations: A Functional Justification for "Star Chamber" Proceedings, 72 YALE L.J. 1227, 1240 n.54 (1963).

21 In Mead Corp., FTC File No. 5710656 [1961-1963 Transfer Binder] TRADE REg. REP. I 16,241 (1963), the Commission set forth the limits of participation by a witness's counsel in FTC investigation proceedings. They were subsequently incorporated into its rules. FTC Rules § 2.9.

22 But see FTC Release (May 24, 1967), 32 Fed. Reg. 8460 (1967). Commissioner Elman dissented from the issuance of Rule $\S 2.9$ as violating the right to counsel guaranteed by § 6(a) of the Administrative Procedure Act. Compare FTC Rules § 2.9, with APA § 6(a), 5 U.S.C. § 555(b) (Supp. III, 1968), and S, Doc. No. 24, 88th Cong., 1st Sess. 221-43 (1963) (Administrative Conference recommendation on right to counsel in administrative proceedings).

23 FTC Rules \& 2.8(c).

24 However, the Indianapolis hearings did permit in camera treatment for trade secrets as well as corporate board and executive committee meeting minutes. See BNA ANTITRUST \& TrADE REg. Rep. No. 42, A-15 (May 1, 1962); FTC Releases (April 27 \& May 3, 1962), reported in 3 TrADE REg. REP. II 10,114.11 (1968). 
injury" to him. ${ }^{25}$ The general policy favoring total disclosure at a public trial is designed to insure the fairness of the trial and to inform the public. The determination of whether the contested information is confidential and deserves private treatment, therefore, requires a careful weighing of many factors. These include the need for public disclosure, the type of information involved, the likelihood and quantum of harm flowing from public disclosure, and the availability of satisfactory alternatives. The need to inform the public tends to weigh heavy in the balance.

Pretrial investigations, on the other hand, serve a very different function. ${ }^{26}$ Their sole objective is the acquisition of information from which the FTC can determine whether the public interest would be served by a prosecution of specific companies or individuals. Their procedures should be tested by the single standard of whether the practice is necessary for a fair determination of probable cause. This standard would seem to preclude pretrial public hearings. Informing the public of the investigation either to demonstrate the Commission's activity in the public interest or to alert unknown persons having relevant information does not justify public disclosure of sensitive data. Press releases announcing complaints, annual reports, speeches, and the like, can be used to inform the public of the Commission's vigilant

\footnotetext{
25 See Gellhorn 411-23; Cohn \& Zuckman, FCC v. Schreiber: In Camera and the Administrative Agency, 56 GEo. L.J. 451, 462-4 (1968).

26 For a persuasive analysis of public pre-prosecutorial investigations in the context of the right to counsel dispute presented by Hall v. Lemke, supra note 19, which reaches conclusions similar to those suggested here, see 72 YALE L.J. 1227, supra note 20. See also, e.g., Murchison, Rights of Persons Compelled to Appear in Federal Agency Investigational Hearings, 62 Mrch. L. REv. 485 (1964); Rogge, Inquisitions by Officials: A Study of Due Process Requirments in Administrative Investigations-I, II, III, 47 MINN. L. REv. 939 (1963), 48 MinN. L. REv. 557, 1081 (1964); Gordon, Right to Counsel in Immigration Proceedings, 45 MinN. L. Rev. 875 (1961); Newman, Federal Agency Investigations: Procedural Rights of the Subpoenaed Witness, 60 Mich. L. REv. 169 (1961); Newman, Due Process, Investigations, and Givil Rights, 8 U.C.L.A.L. REv. 735 (1961); Note, Representation by Counsel in Administrative Proceedings, 58 Colum. L. REv. 395 (I958).

Since the focus of the discussion here is on precomplaint investigations, it should be noted that this analysis is not automatically transferrable to other types of FTC investigations such as those directed solely toward gathering information. The standard for confidential treatment of sensitive data in broad economic inquiries or proposed rule-making hearings in one sense should correspond more closely to adjudicative hearings because one purpose common to both is to inform the public. See FCG v. Schreiber, 381 U.S. 279, 293-4 (1965). On the other hand, this is not the only function of such investigations and subpoenaed witnesses are not involved in determining the innocence of themselves or another. Thus, whatever the propriety of using information investigations in other contexts to regulate by publicity, see, e.g., Rauh \& Pollitt, Right to and Nature of Representation Before Congressional Committees, 45 MINN. L. REv. 853 (1961), FTC information hearings require a meticulous balancing of the significance of public disclosure against the potential injury to the opponent of release, and only when the former outweighs the latter should disclosure follow. See Cohn \& Zuckman, supra note 25, at 462.
} 
efforts. In the unusual situation where the agency is unaware of who might have necessary information, any general notice seems adequate. The propriety of the Commission's decision to prosecute will become apparent when evidence is presented at trial, and judicial injunctions are available to prevent the rare case of investigative harassment by an agency. ${ }^{27}$

This analysis suggests that when an investigated party asserts that particular information deserves confidential treatment, the request should be granted unless the proponent of public disclosure demonstrates either a clear need for such disclosure or danger of serious public harm if the information is not disclosed. In effect, the presumption in favor of public disclosure at adjudicative hearings is reversed to one of non-disclosure in public pretrial investigations. If determining the question of confidentiality requires that secret information be examined, this preliminary disclosure must be at a secret hearing or any subsequent protection would become meaningless. ${ }^{28}$ Then, if confdential treatment is warranted, in camera treatment such as that relied upon to protect sensitive material at the hearing level would appear appropriate..$^{2 \theta}$

Some may object that the suggested procedure effectively undermines the Commission's power to hold pre-prosecution hearings in public. This criticism misses the mark, however, since the limitation affects only the treatment of confidential information and leaves un-

27 See, e.g., Frito-Lay, Inc. v. FTC, 380 F.2d 8 (5th Gir. 1967); Adams v. FTC, 296 F.2d 861, 866-7 (8th Cir. 1961), cert. denied, 369 U.S. 864 (1962); cf. Rettinger v. FTC, 392 F.2d 454, 457-8 (2d Cir. 1968). See also Cohn \& Zuckman, supra note 25, at 464-7; Withrow, supra note 8, at 486; Comment, Procedures to Challenge the Process of Administrative Agencies, 30 U. CHI. L. Rev. 508 (1963). But see Anheuser-Busch, Inc. v. FTC, 359 F.2d 487 (8th Cir. 1966); Beatrice Foods Co. v. FTC, 1966 Trade Cas. I 71,733 (D.D.C. 1966).

28 It has been suggested that a secret preliminary hearing procedure should apply to all determinations of demands for confidential treatment in investigations, whether such hearings are directed toward subsequent prosecutions, proposed legislation, broad economic inquiries, or new substantive rules. Cohn \& Zuckman, supra note 25, at 459-62. This has not presented any serious problem in FTC public precomplaint investigations, however, since the Commission apparently has granted in camera status to sensitive data liberally; nor has it rejected any requests that this determination be made in secret session. See note 24 supra. However, it does not seem likely that an examiner would need to examine the confidential data itself to rule on the in camera request in most cases. Nevertheless, the suggestion that the procedure be institutionalized (and thereby regularized) by incorporating it explicitly in the Commission's rules seems preferable to current ad hoc methods, where the secrecy of preliminary hearings depends on the predisposition of the examiner. Cf. Koppers Co., FTC Dkt. No. 8755, 3 TRADE REg. REP. ๆf 18,577, at 20,919 n.8 (Interlocutory Order, Nov. 1, 1968).

29 If an investigated party is dissatisfied with the Commission's determination, limited judicial review and protection is then available. See FCC v. Schreiber, 381 U.S. 279, 290-1, 296 (1965). But see Note, FCC v. Schreiber-A New Weapon in the Administrative Arsenal?, 20 Sw. L.J. 374, 38I-3 (1966). 
touched much of the information which may be brought out in an investigation. For example, if the information sought at the investigation has been previously disclosed by the witness, or if its public disclosure would cause no particular injury, the presumption in favor of a request for confidentiality could be readily rebutted.

It should be pointed out, however, that the propriety of public prosecution investigatory hearings is very much in question. One need not adopt the view that the use of pretrial investigation as a publicity sword turns all information into sensitive or confidential data ${ }^{30}$ to feel that the FTC should decide that public pretrial investigations are inappropriate because of problems of undue disclosure. Though judicial dicta suggest that public investigations are not unconstitutional, ${ }^{31}$ the cases seem distinguishable and the dicta ill-conceived. ${ }^{32}$ In any case, there appears to be no valid reason to support public precomplaint investigations and several positive reasons to oppose them. In addition to the objections already stated, there is the overriding concern that such investigations may generate substantial adverse publicity against the investigated company. Although the harm to the investigated party's reputation may be similar to that suffered by a respondent in a public adjudicative hearing, the safeguards available in FTC trials are absent in preprosecution investigations. The public character of a trial is designed to keep judge and witness fair and honest; respondent can crossexamine witnesses and present his own case, thus minimizing any harm. Since pretrial investigations cannot lead to official sanctions, the credibility of witnesses and fairness of an examiner's rulings are not generally subject to challenge. Similarly, an investigated party's right to counsel is limited-he is not allowed to "interrupt" the proceedings with questions or to present rebuttal evidence, although the Commis-

30 Cf. Rourke, Law Enforcement Through Publicity, 24 U. CHI. L. REv. 225 (1957).

31 Hannah v. Larche, 363 U.S. 420,446 (1960) (ruling on scope of counsel's participation in Civil Rights Commission investigative hearings; dictum that FTC rules limiting participation by witness's counsel in investigative proceedings were not constitutionally defective). Although two justices noted that the CRC was authorized to hold public hearings (id. at 492,496 ), it is not clear from the opinions in Hannah whether a public hearing was there contemplated (but an affidavit filed by GRC's general counsel in Hall v. Lemke, supra note 19 , indicates that it was). 72 YALE L.J. 1227, note 20 supra. Justice Frankfurter's concurring opinion, however, stressed the statutory protections (including a requirement of executive session) where public disclosure could be harmful to an individual. 363 U.S. at 490-2. Moreover, the court's discussion of the FTC analogue does not indicate any judicial awareness of public precomplaint investigations by the FTC. See id. at 446, 456-9. And, of course, all such proceedings had been held in secrecy before that date.

32 See Withrow, supra note 8, at 474-5; Pollock, supra note 8, at 25; 72 YALE L.J. 1227, 1232-42, note 20 supra. But see Dixon, The Federal Trade Commission: Its Fact-Finding Responsibilities and Powers, 46 MARQ. L. Rev. 17, 27-28 (1962). 
sion usually will accept subsequent clarifications and explanatory memoranda. ${ }^{33}$ While the public interest in disclosure weighs heavy after it has been found that probable cause exists, no such counterbalance is present during precomplaint proceedings.

\section{Acquiring Confidential Information}

Since pretrial investigations today are held in secret session with neither public notice nor subsequent disclosure, the balance of this discussion of the treatment of confidential information at the investigative stage concentrates on closed rather than open investigation. Acquisition of information by the Commission in such surroundings, at least initially, would not appear to raise any questions of confidential treatment. The party compelled to submit data (or one who does so voluntarily) need not claim confidential treatment; nonpublic treatment is accorded automatically. ${ }^{34}$ However, this does not mean that such witnesses do or should make sensitive data freely available without giving notice of its confidential character or need for secret handling. Confidential treatment at the precomplaint stage may be no assurance of limited circulation as the investigative process becomes adjudicative. In fact, the objective of the precomplaint investigation is to obtain evidence for use by the FTG during the public hearing.

Thus, questions of confidentiality at this stage may involve assertions that the FTC is not entitled to the information or that it should be disclosed to the Commission only under the most stringent judicial supervision with continuing secrecy assured by the threat of contempt hanging over any unauthorized disclosure ${ }^{35}$ In contrast to the discovery stage, where both the respondent and the Commission will at various times seek disclosure of information, the desire for disclosure is onesided during the investigatory phase. Only the FTC can initiate an investigation or request information; investigated parties or other informants are bystanders and may not participate in the investigatory process. $^{36}$ Since the investigator generally has access to FTC files, the

33 See FTC Rules § 2.9(b)(5); cf. Mississippi River Fuel Corp., FTC Dkt. No. 8657 (Initial Decision Jan. 29, 1968).

34 Section 10 of the FTC Act applies criminal penalties to disclosure of any information in FTC files unless such disclosure is authorized by the Commission. 15 U.S.C. \$ 50 (1964). Section $6(f)$ further admonishes the FTC not to publish trade secrets. 15 U.S.C. $\$ 46(f)$ (1964). These provisions are reinforced by Commission rules. FTC Rules §§ 4.10(a)(2) \& (6), $4.10(d)$.

35 See, e.g., FTC v. Green, 252 F. Supp. 153 (S.D.N.Y. 1966); FTC v. Nat'l Biscuit Co., 18 F. Supp. 667 (S.D.N.Y. 1937); cf. FCC v. Schreiber, 381 U.S. 279 (1965).

36 The wording of the statute and its legislative history lead us to the conclusion that the exercise of the procedure outlined in $6(\mathrm{~b})$ was reserved exclusively to the F.T.C. in its function as protector of the public interest. There is no indication 
sources he will mine for information are either private firms and individuals or other government agencies.

From Private Sources. The congressional authorization of the Commission's investigatory power is not conditioned in any way on the nature of the information sought or the uses to which it may be put. ${ }^{37}$ (Only the general limitations on unauthorized disclosure of the contents of FTC files apply.) Nevertheless, holders of information which fits within current doctrines of testimonial privilege apparently can assert that such information need not be disclosed.

Despite congressional silence and the lack of guidance from FTC rules, required disclosure of information within the attorney-client and work product privileges is probably not within the Commission's investigatory prerogatives. ${ }^{38}$ The Commission has recognized the attorneyclient doctrine in rejecting respondent's attempts to discover complaint counsel's case, ${ }^{39}$ and, while the precomplaint investigatory phase is distinguishable and the privilege arguably is inapplicable since no action has been (or may ever be) brought against the informant, recent expansions of the right to counsel support the view that this privilege is of cardinal importance at the investigative level and should not be impaired without overriding cause. ${ }^{40}$ Analogous grand jury proceedings likewise recognize the privilege. ${ }^{41}$

A similar analysis requires recognition of the work product privilege in Commission investigations. Although the issue has never been decided by the Commission, by analogy again to FTC discovery pro-

that this extraordinary power was ever meant to be utilized by a private party to an enforcement proceeding.

Union Bag-Camp Paper Corp. v. FTC, 233 F. Supp. 660, 664 (S.D.N.Y. 1964).

37 Enforcement, however, is conditioned on meeting the requirements of $\$ \S 6,9$, and 10 of the FTC Act and of proper authorization, relevance, and reasonableness. 15 U.S.C. $\S \S 46,49,50$ (1964); see Oklahoma Press Publ. Co. v. Walling, 327 U.S. 186 (1946).

It should be noted that the various testimonial privileges not examined are inapplicable to FTC proceedings. See Gellhorn 406.

38 This conclusion is stated categorically by a prominent FTC practitioner, but without citation of direct authority. F. ROWE, Price Discrimination UNDER The RoBinson-Patman ACr 486 (1962).

39 E.g., Viviano Macaroni Co., FTC Dkt. No. 8666 [1965-1967 Transfer Binder] TrAdE REg. REP. I 17,467 (1966); accord, CAB v. Air Transport Ass'n, 201 F. Supp. 318 (D.D.C. 196I).

40 See note 21 and authorities cited notes $22 \& 26$ supra; cf., e.g., United States v. Wade, 388 U.S. 218, 224 (1967); EIsen \& Rosett, Protections for the Suspect Under Miranda v. Arizona, 67 Colum. L. REv. 645 (1967).

41 See Continental Oil Co. v. United States, 330 F.2d 347 (9th Cir. 1964). See generally Comment, The Rights of a Witness Before a Grand Jury, 1967 Duke L.J. 97. See also United States v. Morton Salt Co., 338 U.S. 632, 642-3 (1950) (analogizing FTC investigative powers to functions of the grand jury). There may be limits, however, to the grand jury analogue. See Note, The Distinction Between Informing and Prosecutorial Investigations: A Functional Justification for "Star Chamber" Proceedings, 72 YALE L.J. 1227, 1236-7 (1963). 
ceedings where the privilege now is generally recognized, ${ }^{42}$ it seems clear that the FTC will honor the work product privilege during its investigations. ${ }^{43}$ On the other hand, both the FTC and the courts will reject any attempt to assert a claim of accountant-client privilege not recognized at common law. ${ }^{44}$ While the leading decision can be questioned on other grounds, ${ }^{45}$ the denial of this privilege in FTC investigations seem proper since no persuasive case has yet been made for the protection of this relationship. ${ }^{46}$

When compelled, a witness cannot avoid disclosure of trade secrets or of other confidential information to an FTC investigator. The one exception involves retained copies of confidential census reports which Congress has ruled are immune from FTG scrutiny. ${ }^{47}$ Some have argued that section 6(f) of the FTC Act, which prohibits the Commission's publication of trade secrets, restricts the agency's right to demand such information in an investigation; but such arguments have rightfully failed. ${ }^{48}$ Contentions that Commission requests for sensitive data

42 E.g., R. H. Macy \& Co. v. Tinley, 249 F. Supp. 778 (D.D.C. 1965); Koppers Co., FTC Dkt. No. 8755 (Interlocutory Order Aug. 14, 1968); id. (Interlocutory Order July 2, 1968); Viviano Macaroni Co., FTC Dkt. No. 8666 [1965-1967 Transfer Binder] TRADE REg. REP. If 17,467, at 22,752 (1966); Graber Mfg. Co., FTC Dkt. No. 8038 [1965-1967 Transfer Binder] Trade Reg. Rep. If 17,409 (1965); Bakers Franchise Corp., 56 F.T.C. 1636, 1637 (1959).

43 The vital importance of preserving inviolate the work product of attorneys so eloquently detailed by the Supreme Court in its opinion in Hickman v. Taylor applies with even greater force to the investigatory work of Government attorneys who are engaged not only in the representation of their client, but in the protection of the public interest.

L. G. Balfour Co., FTC Dkt. No. 8624 [1965-1967 Transfer Binder] Trade Reg. Rep. If 17,532 , at 22,799-800 (1966) (footnotes omitted).

44 FTC v. St. Regis Paper Co., 304 F.2d 731 (7th Cir. 1962); accord, Falsone v. United States, 205 F.2d 734 (5th Cir.), cert. denied, 346 U.S. 864 (1953).

45 See Gellhorn 407 nn.35-6; Withrow, supra note 8, at 483.

46 See 8 J. WigMore, Evmence \& 2286 (MCNaughton rev. 1961); C. MCCorMICK, EvmENCE $\S 81$ (1954); Note, Evidence-Privileged Communications-Accountant and Client, 46 N.C.L. REv. 419, 423-7 (1968).

47 In its first use of $\S 6(\mathrm{~b})$ reports in a precomplaint investigation, the FTC sought to compel respondent to disclose retained copies of confidential reports which it had submitted to the Census Bureau. Despite the statement on the Census Bureau's report form that the "report is confidential" and could not be "used for purposes of taxation, investigation or regulation," the Supreme Court held that retained copies in a private party's files could be demanded by the FTC since the Act did not expressly prohibit such demands. St. Regis Paper Co. v. United States, 368 U.S. 208 (1961). The Commission triumph became a pyrrhic victory, however, when Congress nullified the decision by providing that retained copies of census reports were "immune from legal process" and could not be used involuntarily against the respondent in any "judicial or administrative proceeding." 13 U.S.C. § 9(a) (1964); see 87th Cong., 2d Sess., House, Comm. on Post Office \& Civil Service, Hearings on Confidentiality of Census Reports 7-9 (1962).

48 E.g., FTC v. Cooper, 1962 Trade Cas. ๆ 70,853 (S.D.N.Y. 1962); FTC v. Tuttle, 244 F.2d 605, 616 (2d Cir.), cert. denied, 354 U.S. 925 (1957); FTC v. Waltham Watch Co., 169 F. Supp. 614, 621 (S.D.N.Y. 1959). 
should be subject to stringent court orders insuring confidential treatment have generally been more successful. ${ }^{49}$ In the past, courts have commonly conditioned enforcement of administrative subpoenas upon an agency's compliance with such protective orders. ${ }^{50}$ But since the Supreme Court's decision in $F C G v$. Schreiber ${ }^{51}$ that a protective order is premature until the subpoenaed information is made available to the agency and the agency has had an opportunity to rule upon respondent's request for confidential treatment, such restrictions no longer should be imposed by court enforcement of FTC investigative requests. ${ }^{52}$ On the other hand, voluntary submission to the Commission of sensitive data, contingent upon confidential treatment, may be viewed by the Commission as making it honor-bound to observe that commitment. ${ }^{53}$

From Government Sources. Private parties are not the only source of data useful in FTC prosecutions. As the government has become the largest single depository of business information, ${ }^{54}$ the Commission's ability to acquire information from files of other government agencies would seem increasingly important.

Cooperation between the FTC and other government departments

49 In FTG v. Menzies, 145 F. Supp. 164, 171 (D. Md. 1956), aff'd, 242 F.2d 81, 84 (4th Cir.), cert. denied, 353 U.S. 957 (1957), the court's restrictive order provided:

No part of the documentary evidence should be made public and available to the competitors of the several respondent corporations unless it is necessary to do so in the proper enforcement of the law. If requested by the respondents, the Commission should follow its practice of placing the documents offered in evidence in a confidential file. ...

But see FTC v. Hallmark, Inc., 265 F.2d 433 (7th Cir. 1959), aff'g, 170 F. Supp. 24 (N.D. III. 1958).

50 E.g., FCC v. Cohn, 154 F. Supp. 899, 913 (S.D.N.Y. 1957).

51381 U.S. 279 (1965).

52 FTC v. Green, 252 F. Supp. 153 (S.D.N.Y. 1966); cf. United States v. Assoc. Merchandising Corp., 261 F. Supp. 553 (S.D.N.Y. 1966). But see Anheuser-Busch, Inc. v. FTC, 359 F.2d 487 (8th Cir. 1966); Beatrice Foods Co. v. FTC, 1966 Trade Cas. If 71,733 (D.C. Cir. 1966); FTC v. Continental Can Co., 267 F. Supp. 713 (S.D.N.Y. 1967).

53 For example, in denying discovery of information from its investigative file to a respondent in an adjudicative proceeding, the FTC commonly argues, as it did in Sperry \& Hutchinson Co., FTC Dkt. No. 8671 [1965-1967 Transfer Binder] Trade REG. REP. If 17,505 , at 22,779 (1966), that:

The persons and businesses who supply the kind of information concerned are frequently reluctant to have their affairs made public and they expect, in providing this information to the Commission, that its confidentiality will be maintained wherever possible.

See also H. P. Hood \& Sons, Inc., 58 F.T.C. 1184, 1190 (1961).

54 H. R. REP. No. 52, 89th Cong,, 1st Sess. 14-54 (1965); see Ikard, The Scope, Volume and Expense Involved in Furnishing Requested Information, ABA MINERAL \& NATURAL RESOURCES LAW SECTION 4 (1965). See generally Hoffman, Industry Reports to GovernmentSome Legal Problems, ABA Mineral \& Natural Resources Law Section 8 (1965); Bowman, The Role of the Bureau of the Budget, ABA MiNeral \& Natural Resources LAw Section 25 (1965), both reprinted in 18 AD. L. REv. 80 \& 109 (Fall, 1966). 
takes many forms, including liaison with the Justice Department to coordinate antitrust enforcement..5 Formal arrangements or agreements have been entered into by the FTG with the Food and Drug Administration, ${ }^{56}$ the Federal Communications Commission, ${ }^{57}$ and the Bureau of Customs $\mathrm{s}^{58}$ to avoid unnecessary overlapping and duplication of effort. The FTC also has informal arrangements with the Bureau of Standards, the Post Office Department, and the Patent Office..$^{59}$ More significant on the surface in terms of Commission power to obtain information in a precomplaint investigation is the provision of section 8 of the FTG Act that all federal departments are obliged to furnish, at the Commission's request, any papers or information in their files on any corporation subject to the FTC's jurisdiction. ${ }^{60}$ However, this provision is effective only when the President directs that other government agencies cooperate with the Commission, and as yet no executive order has been issued under this authority. This provision apparently has been permitted to lie dormant because the Commission can require private parties to produce information even though that information

55 Memorandum of Agreement between FTC and Justice Department, (1948), reprinted in part in Report of the AtTorney General's National Commitee to Study the ANTrTRust LAws 374-7 (1955). See also FTC Rules § 4.6; Rockefeller, Antitrust Enforcement: Duopoly or Monopoly, 1962 WIs. L. REv. 437.

The Commission's recent refusal to disclose the details of this liaison arrangement to the author illustrates the FTC's penchant for secrecy and misuse of confidentiality labels. This two page agreement, drafted by Commissioner MacIntyre when he was an FTC staff member, merely details the establishment of a duplicate card filing system, recording matters under investigation by each agency. Nevertheless, when a request for a copy of this agreement was made to the FTC's general counsel, disclosure was refused because the agreement "is in the Confidential files of the Commission, and, for that reason, we are unable to furnish you with a copy of it." Letter from James McI. Henderson, FTC General Counsel, to Ernest Gellhorn, July 9, 1968. In contrast, a similar request to the Assistant Attorney General in charge of the Antitrust Division of the Justice Department resulted in a routine release of the memorandum agreement. Letter and enclosure from Robert $A$. Hammond, IIX, Acting Assistant Attorney General, Antitrust Division, to Ernest Gellhorn, July 25, 1968. This practice is another illustration of the Commission's blind reliance on the location rather than the contents of a document to determine its confidentiality. See note 175 infra and accompanying text.

56 FTC Release (June 9, 1954); id. (Jan. 23, 1968). See also Charles Pfizer \& Co., FTC Dkt. No. 7780 [1963-1965 Transfer Binder] Trade REg. REP. \ 17,102 (1964).

5722 Fed. Reg. 2318 (1957).

58 FTC Release (Jan. 24, 1956).

59 I954 FTC ANN. REP. 9; Letter from James McI. Henderson, General Counsel, FTC, to Ernest Gellhorn, July 8, 1968; see Address by Frank C. Hale, Acting Director, FTC Bureau of Deceptive Practices, to Conference of Postal Inspectors, Washington, D.C., March 13, 1968.

60 I5 U.S.C $\$ 48$ (1964). Compliance with $\S 8$ avoids the general prohibition (in 18 U.S.C. $\S 1905$ (1964); $44 i d . \S 4$ ) of disclosures of trade secrets or confidential information by federal employees except as authorized by law. 
is already in another government agency's files. ${ }^{61}$ Moreover, since 1947 the FTG has been authorized under the Internal Revenue Code to inspect corporate income tax returns; ${ }^{62}$ no problem of confidentiality will develop under this authority because confidentiality must be maintained by the FTG except for statistical tabulations which do not identify any taxpayer.63 Finally, there is some information which cannot be disclosed to the FTC. Compulsory returns filed with the Census Bureau are in this category; in contrast with the former rule regarding retained copies in private files, they always have been confidential and cannot be disclosed for regulatory purposes. ${ }^{64}$

Formal FTC reliance on its power to acquire information from other government departments, then, somewhat parallels the early record of the FTC's use of its investigatory powers to compel information from private sources. That is, despite extensive formal powers, the Commission does not appear to have relied upon them, depending instead on informal cooperation. Whether the past decade's experience with more extensive formal investigatory demands on private parties will be repeated in the Commission's search for prosecutorial information in the files of other government agencies seems doubtful, however. Despite government's expanding role as an information bank, most data useful in FTG prosecutions is probably only in private hands. Moreover, political realities of agency operation undoubtedly will continue to discourage many formal requests. ${ }^{65}$

Nonetheless, since one purpose of FTC precomplaint investigations is to gather information to be produced at a later public hearing, disturbing questions of confidentiality could arise. When one government agency makes available to the FTG information considered by a private source to be "confidential," should the disclosing agency or the FTC reveal that fact to the private source? Or, would it be preferable to allow the other agency to protect its private sources by conditioning disclosure on continued confidential treatment despite possible conflict with FTG policy on confidentiality in adjudicative hearings? ${ }^{\text {po }}$

61 See FTC v. Dilger, 276 F.2d 739, 745 (7th Gir.), cert. denied, 364 U.S. 882 (1960); General Trade Schools v. United States, 212 F.2d 656, 661 (8th Cir. 1954).

62 Internal Revenue Code of 1954, § 6103(a); see Exec. Order No. 10,908, 3 C.F.R., 1959 1963 Comp. 437 (1961); Exec. Order No. 10,544, 3 G.F.R., 1954-1958 Comp. 198.9 (1954); Exec. Order No. 10,090, 3 C.F.R., 1949-1953 Comp. 286-7 (1949); Exec. Order No. 9833, 3 C.F.R., 1943-1948 Comp. 626 (1947).

63 Treas. Reg. \$ 301.6103(a)-106(a) (1961).

6413 U.S.C. $\$ 9$ (a) (1964). For another example of such a prohibition, see an amendment to the Interstate Commerce Act, 49 U.S.C. § 320(f) (1964).

o5 Cf. St. Regis Paper Co. v. United States, 368 U.S. 208, 217 (1961).

60 This alternative is similar to the proposal of Cohn \& Zuckman, supra note 25, at 472 , that the informing agency "request that the confidentiality of the material be re- 
(The latter issue also occurs when the confidential information was developed by the disclosing agency.) Without attempting a thorough examination of these problems in the abstract, fairness suggests a notice standard as a minimum. Just as the FTC will disclose the purpose of the investigation to an investigated party or informant, ${ }^{67}$ so the FTC or the informing government agency should notify the private source that information he supplied is being disclosed to the FTC. The private party, in turn, should be given an opportunity to request continued confidential treatment or to appear before the FTC to explain why public disclosure would be inappropriate.

\section{Disclosing Confidential Information}

Adhering to the practices of all prosecuting agencies, FTG investigative files are treated as confidential and will not be made public at the precomplaint stage. ${ }^{68}$ Confidentiality serves several purposes with which disclosure might interfere. First, it protects innocent investigated parties. An investigation is designed only to determine whether probable cause exists and whether a prosecution is in the public interest. ${ }^{69}$ Often, although one or both is not satisfactorily demonstrated and no complaint is issued, a disclosure of FTC files would reveal material harmful to such "cleared" parties. Release of investigatory material could also improperly harm those against whom a complaint is actually brought. Generally, complaint investigations concentrate on gathering inculpatory information; disclosure of investigatory files would not be likely to reveal an equal quantity of exculpatory material. The respondent has not yet had an opportunity to present his case; probable cause is not the equivalent of guilt. And even if respondent is later determined to be a law violator, disclosure seems improper because investigatory files are not "balanced" and would not contain counterbalancing or mitigating evidence.

Disclosure of investigatory files might also interfere with the Commission's prosecutorial mission. Complaint counsel's case would be revealed prematurely. Consent negotiations may still be possible; prosecution may be more difficult if investigatory files were opened except

spected." Since their article concentrates on preliminary in camera hearings, however, they did not consider other alternatives or explain their choice.

67 FTC Rules $\S 2.6$.

68 FTC Rules $\S 4.10(\mathrm{a})(6)$. See also id. $\$ \S 2.2(\mathrm{~d}), 4.10(\mathrm{a})(2)$. But the investigational witness generally is allowed to obtain a transcript of his testimony. Id. $\$ 2.9$ (a); see 5 U.S.C. \$ 555(b) (Supp. III, 1968).

60 The "public interest" limitation on FTC complaints, however, applies only to prosecutions brought under $\S 5$ of the FTC Act. See Webb-Crawford Co. v. FTC, 109 F.2d 268, 269 (5th Cir.), cert. denied, 310 U.S. 638 (1940). See generally French, The Federal Trade Commission and the Public Interest, 49 Mins. L. REV 539 (1965). 
under controlled discovery; and investigatory files may contain irrelevant (and harmful) materials or the nondiscoverable work product of the investigator. Further disclosure, would reveal the identity of complainants upon whom the Commission relies so heavily; this "informer's privilege" protects a complainant against economic or other harassment. Thus, there seems little reason to doubt the appropriateness of the general rule that investigative files are secret. ${ }^{70}$ The rules prohibiting disclosure are not likely to be abandoned. They have long been followed by prosecuting agencies, are often required by statute, and are frequently recognized by the courts. Most judicial contests have concerned attempts to prevent disclosure, not to compel it. ${ }^{11}$ Nor does the recent amendment to section 3 of the Administrative Procedure Act affect FTC investigatory policy. ${ }^{72}$ Despite considerable doubt as to the type and scope of confidential information excluded from its broad disclosure command, ${ }^{73}$ the Freedom of Information Act is relatively clear in exempting all precomplaint investigative files from its reach. ${ }^{74}$

Nevertheless, at least two problems may occur. The first, illustrated by a celebrated case, involves the direct leak of information from the Commission's investigative files by one of its personnel. In 1954 the Commission's chairman divulged the name of a private complainant (whose information had instigated an FTC investigation) to a presidential assistant who passed it on to the investigated businessman. ${ }^{75}$ Strict statutory prohibitions and penalties, ${ }^{76}$ Commission rules, ${ }^{77}$ more cautious Commission personnel, ${ }^{78}$ and the notoriety of the Gold-

70 However, once a complaint is issued, a respondent may be entitled to materials from the investigative files in order to discover Commission counsel's case or to locate exculpatory material, but disclosure then is governed by principles of discovery and is considered in that context.

71 See 1 K. C. Davis, Administrative Law Treatise $\$ 3.13$ (1958).

725 U.S.C. $\$ 552$ (Supp. III, 1968). See also Note, The Federal Freedom of Information Act as an Aid to Discovery, 54 Iowa L. REv. 141, 152 n.73 (1968) (collecting authorities).

73 Compare Attorney General's Memorandum on the Public Information Section of the Administrative Procedure Act 32-34 (1967), with Davis, The Information Act: $A$ Preliminary Analysis, 34 U. CHI. L. REv. 761, 787-92 (1967).

745 U.S.C. \$ 552(b)(7) (Supp. III, 1968); see Davis, supra note 73, at 799-800.

75 The reference, of course, is to one of the indiscretions which cost President Eisenhower's assistant Sherman Adams his job. He secured the name of the private party from FTC Chairman Howrey and revealed it to Bernard Goldfine. H.R. REP. No. 2711, 85th Cong., 2d Sess. 46-50 (1959).

76 15 U.S.C. $\S \S 46(f), 50$ (1964); 18 U.S.C. $\S 1905$ (1964); 44 U.S.C. § 423(b) (Supp. III, 1968).

The FTC has also relied on $\$ 5$ of the FTC Act to prevent the use of confidential intraagency documents for private advertising purposes. Ro-Ed Engineering \& Combustion Co., 28 F.T.C. 1787 (1939).

77 See note 68 supra.

78 Cf., e.g., Viviano Macaroni Co., FTC Dkt. No. 8666, 3 Trade Reg. REp. I 18,246, at 20,643-4 (1968). 
fine affair have maintained the integrity of FTC files since then (although the first two were in force in 1954).

The second problem concerns the demand of private litigants in judicial actions for information in the Commission's investigative files. Various aspects of the doctrine of executive privilege have been asserted by administrative agencies to protect their investigative files from civil process (even against in camera disclosure), and these assertions usually have been successful. ${ }^{79}$ In fact, the complaint of most commentators is that agencies have been too protective and courts too submissive. ${ }^{80}$ Serious problems do not appear to have been raised by demands of private litigants for FTC information. However, private actions are available under some of the acts enforced by the Commission and such demands by private litigants are foreseeable. In this connection, it should be noted that, in opposing compulsory disclosure of investigative files, administrative agencies have concerned themselves only with maintaining the secrecy of their files; no attention has had to be paid specifically to the informant's interests. But if court intervention should become more bold and agency assertions of confidentiality are questioned, then it would seem appropriate for an agency to notify the party who supplied the information in order that he might have an opportunity to object and present his views.

\section{CoMPLAINTS}

Precomplaint investigations end with the decision either to issue a complaint or not to prefer charges. The decision to close the investigatory file without a complaint is not made public and is treated as confidential information. ${ }^{81}$ This procedure, unchallenged except in discovery attempts by disgruntled competitors whose practices were not viewed so favorably by the FTC (and possibly unchallengeable even under the new section 3 of the Administrative Procedure Act), seems appropriate. First, by not issuing a complaint the Commission has not "cleared respondent of any wrongdoing," but has only determined that it would not be in the public interest to bring a complaint now. This decision may be based on the insignificance of the asserted violation,

79 See, e.g., Appeal of the SEC, 226 F.2d 501 (6th Cir. 1955); Timbers \& Cohen, Demands of Litigants for Government Information, 18 U. PIrT. L. REv. 687 (1957); Carrow, Governmental Nondisclosure in Judicial Proceedings, 107 U. PA. L. REv. 166, 181-4 (1958).

80 See, e.g., Hardin, Executive Privilege in the Federal Courts, 71 Yale L.J. 879, 898.905 (1962).

81 See FTC Rules $\S \S 4.9,4.10(\mathrm{a})(6) ;$ cf. Auerbach, The Federal Trade Commission: Internal Organization and Procedure, 48 MrN. L. REv. 383, 431 (1964): "[F]airness to the respondent dictates that he should not be subjected to the unfavorable publicity that attends the issuance of a formal complaint against him unless the enforcement bureau's investigation has gone far enough to convince it that a violation of law has been committed." 
the lack of supporting evidence, or the need for regional or industrywide rather than individual action. Second, release of the decision not to proceed could be damaging to respondent because it suggests that the agency at one time doubted the propriety of the firm's actions. "Where much has been said, something will be believed . . . ."82 Public confusion, noted so often by the Commission in other circumstances (for example, in false advertising cases), may occur; a decision not to proceed might be misunderstood as a decision to prosecute or even as a finding of guilt. Finally, the interest in informing the public of the Commission's activities can be satisfied adequately by general rather than specific announcements-the individual respondent need not be named.

Issuance of a complaint by the FTC, on the other hand, is public information. ${ }^{83}$ This practice, traditionally adhered to by administrative agencies, has been approved by the courts and seems unexceptionable. One court recently concluded that section 6(f) of the FTC Act broadly confers this discretion on the agency. ${ }^{84}$ Earlier, another court relied on the FTC's authority to adopt rules not inconsistent with the Act as supporting public pleadings and hearings. 85 It pointed out that the FTC has discretion under the Act to allow third persons to intervene in adjudicative hearings; ${ }^{86}$ unless the complaint and hearing is public to apprise potential intervenors of the proceeding, the right of intervention becomes meaningless.

The most serious challenge, however, has been to the Commission's practice, adopted in 1918,87 of simultaneously issuing a press release with each complaint. Press releases now are issued by the FTC at four steps in every litigated proceeding-upon issuing the FTC's complaint, filing respondent's answer (unless it asks that no release be issued), releasing the examiner's initial decision, and handing down the FTG's final order. Copies are mailed to 900 publications and overall distribution is around 2,500.88 Except for occasional pressure by consumer

82 Respublica v. Oswald, 1 U.S. 343, 348-9, 1 Dall. 319, 325 (1788).

83 FTC Rules \& $4.9(\mathrm{e})(3)$.

84 FTC v. Cinderella Career \& Finishing Schools, Inc., 5 Trade Reg. Rep. (1968 Trade Cas.) I 72,385, at 85,145 (D.G. Cir. 1968).

85 E. Griffiths Hughes, Inc. v. FTC, 63 F.2d 362, 363 (D.C. Cir. 1933); FTC Act § 6(g), 15 U.S.C. $\$ 46(\mathrm{~g})(1964)$.

86 FTC Act $\$ 5(b), 15$ U.S.C. $\$ 45(b)$ (1964).

87 Compare FTC v. Cinderella Career \& Finishing Schools, Inc., 5 TrAdE REg. Rep. (1968 Trade Cas.) ๆ 72,385, at 85,142 n.3 (D.C. Cir. 1968), with T. BLAISDELL, The FeDERAL Trade Commission 83, 85-6 (1932), and 1925 FTC AnN. Rep. 23. See S. Doc. No. 8, 77th Cong., 1st Sess. 135-6 (1941).

88 BNA ANTtrRust \& Trade Reg. Rep. No. 350, B-1 (March 26, 1968). 
groups, ${ }^{89}$ the real contest here has been to prevent rather than procure publicity for FTC actions. Conceding that pleadings constitute a public record available to all, the question is whether the Commission may attract public attention to the record by focusing the press's attention on that information. Though an appellate court has recently upheld the practice, ${ }^{90}$ there is some pressure in Congress to restrict it..$^{91}$ In introducing legislation which would require that all federal administrative agencies give respondents an equal opportunity to respond when a complaint is issued, one Congressman recently commented that "the [subsequent] finding of innocence rarely catches up to the publicity of the accusations." 92

The issue of an agency's release of disparaging publicity before a final adjudication on the merits, though not strictly a problem of confidentiality inasmuch as the complaint is already public, bears a close resemblance to it. At least two questions are involved: Does the FTC have authority to issue such press releases? Should the Commission publicize complaints—or be required to grant "equal time"whether or not so authorized?93

\section{Authority to Issue Press Releases}

The charge against the Commission is not that press releases are being used in a discriminatory fashion or that they misstate the terms of the pleading, but rather that such publicity is ultra vires and should be enjoined. ${ }^{94}$ Respondents assert that this ordeal by press release is

\footnotetext{
89 See, e.g., 32 CONSUMER's REPORTS 618 (1967); 33 id. 308 (1968). But see Wall Street Journal, April 10, 1968, at 18.

90 FTC v. Cinderella Career \& Finishing Schools, Inc., 5 TrAdE Reg. REP. (1968 Trade Cas.) I 72,385 (D.C. Cir. 1968).

91 S. 518 \& 924, 90th Cong., 1st Sess. (1967). H.R. 6163, 90th Cong., 1st Sess. (1967). Similar proposals, however, have been before Congress before; their history can be traced to at least the minority report of the Attorney General's Committee on Administrative Procedure. S. Doc. No. 8, 77th Cong., 1st Sess. 221 (1941); see Note, Disparaging Publicity by Federal Agencies, 67 Colum. L. Rev. 1512, 1513 n. 4 (1967).

92 Extension of Remarks of Rep. Herbert Tenzer, 113 CoNG. REc. A2291 (daily ed. May 9, 1967); see J. Landis, The Administrative Process 110 (1938); cf. Respublica v. Oswald, 1 U.S. 343, 348-9, I Dall. 319, 324 (1788): "[M]any will read the charge, who may never see the answer...."

\$3 For a collection of authorities and a general discussion concentrating primarily on the authority of administrative agencies to issue disparaging publicity when instituting adjudicatory proceedings, see Note, Disparaging Publicity by Federal Agencies, 67 CoLum. L. REv. 1512 (1967). See also Lemov, Administrative Agency News Releases: Public Information Versus Private Injury, 37 GEO. WASH. L. REv. 63 (1968) proposing that agencies be granted specific authority to issue certain press releases if simultaneous reply is allowed and suggesting amendment of the Federal Tort Claims Act to allow monetary damages.

94 E.g., FTC v. Cinderella Career \& Finishing Shools, Inc., 5 Trade Reg. Rep. (1968 Trade Case.) If 72,385, at 85,146 n.10 (D.C. Cir. 1968). Discriminatory or inaccurate press
} 
neither expressly nor impliedly authorized by Congress and that in issuing the release the agency has prejudged the case in violation of constitutional standards of due process.

Both arguments were rejected recently in FTC $v$. Cinderella Career of Finishing Schools, Inc., ${ }^{95}$ where the Court of Appeals for the District of Columbia Circuit overturned a district judge's prohibition of "factual news release[s] concerning pending adjudicatory proceedings" brought under section 5 of the FTG Act. Not doubting that the press release would cause irreparable injury and if unauthorized would entitle respondent to an injunction, the court found ample authority for this Commission practice. Under section $\mathbf{5}$ the Commission is charged with eliminating unfair and deceptive business practices; ${ }^{\circ 6}$ the basic purpose of the Act is to protect the public. In addition, section 6(f) specifically authorizes release of information as the FTC deems expedient in the public interest. ${ }^{97}$ Relying on this statutory structure, the court concluded that

the Commission, acting in the public interest, [has authority] to alert the public to suspected violations of the law by factual press releases whenever the Commission shall have reason to believe that a respondent is engaged in activities made unlawful by the Act which have resulted in the initiation of action by the Commission. The press releases predicated upon official action of the Commission constitute a warning or caution to the public, the welfare of which the Commission is in these matters charged.98

Congressional awareness and acquiescence in this practice was relied upon for additional support.

One judge, while concurring in the court's conclusion that press releases were authorized here, objected to this wholesale approval of all FTC press releases, at least in section 5 cases. He observed, first, that

releases would seem to present an easier case. See B. C. Morton Int'I Corp. v. FDIC, 305 F.2d 692 (1st Cir. 1962).

955 Trade Reg. Rep. (1968 Trade Cas.) $\int 72,385$ (D.C. Cir. 1968), rev'g, 1967 Trade Cas. If 72,072 (D.D.C. 1967).

96 FTC Act $\$ 5(a)(1), 15$ U.S.C. \$ 45(a)(1) (1964): "Unfair methods of competition in commerce, and unfair or deceptive acts or practices in commerce, are declared unlawful." 97 The commission shall also have power-

(f) To make public from time to time such portions of the information obtained by it hereunder, except trade secrets and names of customers, as it shall deem expedient in the public interest; and to make annual and special reports to the Congress and to submit therewith recommendations for additional legislation; and to provide for the publication of its reports and decisions in such form and manner as may be best adapted for public information and use.

FTC Act $\S 6(\mathrm{f}), 15$ U.S.C. 46(f) (1964) (emphasis added).

985 Trade Reg. Rep. (1968 Trade Cas.) If 17,385, at 85,145-6 (D.C. Cir. 1968). 
the court's analysis does not square with the Commission's justification. The FTC justified the press release not as a warning to the public but rather as part of its public information function. ${ }^{99}$ (And in passing on the Commission's action, the court is confined to reviewing the grounds invoked by the Commission.) $)^{100}$ Looking to that justification, Congress's authorization to the FTC to convey information was limited (in addition to not divulging trade secrets and customer names) to such information "as it shall deem expedient in the public interest."101 This Judge Robinson reads as imposing two preconditions to disclosing information: "The first is a judicious exercise of administrative discretion preceding a resolve to publish, ... [ [and the second] is expedience of the disclosure in the public interest." 102 Nor does it follow automatically that an informational news release is proper in all false advertising cases.

$[B]$ oth the discretional function and the Commission's determination in terms of the public interest clearly require adequate consideration and suitable weighing of any damage to private property which widespread publicity of unadjudicated charges may be calculated to produce. ${ }^{103}$

Although the record did not clearly disclose that the Commission exercised its discretion only after making this determination, it also did not indicate that the FTC had abused its authority; from the record it appeared that the FTC could have concluded that the public interest would be served in this case by pursuing its standard news release policy. ${ }^{104}$

99 The Commission's explanation, as quoted in the concurring opinion, was:

Since complaints fall within the category of public information, the objective of the Commission's Office of Information, in issuing factual news releases, is to provide a means whereby such public information is made available, simulta. neously, and on an orderly basis, to the bar, industry members, the press, and interested members of the public.

5 Trade Reg. Rep. (1968 Trade Cas.) If 17,385, at 85,148 (D.C. Cir. 1968). See also S. Doc. No. 186, 76th Cong., 3d Sess. 14 n.38 (1940): "This practice [of issuing a press release upon service of the complaint] is said to serve two purposes: (1) To insure a correct statement of the Commission's action, and (2) to provide equal treatment for all newspapers and press services."

100 FTC v. Universal-Rundle Corp., 387 U.S. 244, 250, 252 n.5 (1967); see American Trucking Ass'ns v. United States, 364 U.S. 1, 13-14 (1960); Unemployment Compensation v. Aragon, 329 U.S. 143, 155 (1946); SEC v. Chenery Corp., 318 U.S. 80, 87 (1943).

101 See supra note 97.

1025 Trade REg. REP. (1968 Trade Cas.) I 72,385, at 85,150 (D.C. Cir. 1968).

$103 \mathrm{Id}$. at 85,151 .

104 Except for constitutional questions, the court's review was limited to determining whether the issuance of a press release was within the FTC's delegated powers, and, if within the Commission's powers, whether the FTC's discretion was abused or applied arbitrarily. E.g., Moog Indus., Inc. v. FTC, 355 U.S. 411, 414 (1958); National Broadcasting Co. v. United States, 319 U.S. 190, 224 (1943). 
The second claim-of agency prejudgment of respondent's case against him - was disposed of more easily. No court has accepted the argument that a press release describing an agency's complaint presents an insurmountable obstacle to a fair, objective hearing and judgment. ${ }^{105}$ Moreover, in the FTG, among the several "judges" of respondent's case, only the chairman, who merely checks the press release for factual accuracy, ever sees it before it is released; the release itself is descriptive rather than interpretive, adhering closely to the actual wording of the complaint. As both courts and commentators have pointed out, the due process objection is actually a misdirected attack on the combination of prosecutorial and adjudicative functions in the FTC-a joinder sustained by a long line of judicial decisions. ${ }^{106}$

In addition, the court could have argued that the FTC has implied authority to issue press releases because of the nature and responsibility of the agency. ${ }^{107}$ That is, where the agency is charged with preventing public deception by unfair commercial conduct, it has implied power to notify the public and warn them of those most likely to be using such prohibited practices. As the Supreme Court declared in another context: "It would be an unduly restrictive view of the scope of the duties of a policy-making executive official to hold that a public statement of agency policy in respect to matters of wide public interest and concern is not action in the line of duty." 108 On the other hand, this suggested rationale does not go beyond justifying FTC pretrial press releases in those cases where substantial public harm is likely without the warning; it is not support for the present policy of issuing releases in all cases. ${ }^{109}$

Despite the array of judicial authority upholding agency power to issue pretrial press releases, many of the arguments supporting such

105 FTC v. Cinderella Career \& Finishing Schools, Inc., 5 Trade Reg. REP (1968 Trade Cas.) I 72,385, at 85,146-7 (D.C. Cir. 1968); See Pangburn v. CAB, 311 F.2d 349, 356 (Ist Cir. 1962); 2 K.C. Davis, Administrative Law Treatise § 13.10, at 238 (1958).

106 See generally Note, Disparaging Publicity by Federal Agencies, 67 Colum. L. REv. 1512, 1513-4 (1967).

107 Id. at 1521 .

108 Barr v. Matteo, 360 U.S. 564, 575 (1959) (Harlan, J., announcing judgment in an opinion signed by four Justices) (defamation action against public official for libelous press release). The gist of this position was summarized by Mr. Justice Black in the same case: "The effective functioning of a free government like ours depends largely on the force of an informed public opinion." 360 U.S. at 577. This rationale was the justification given respondent by the FTC in Cinderella. See note 99 supra and accompanying text. See also FTC v. Cinderella Career \& Finishing Schools, Inc., 5 Trade Reg. REP. (1968 Trade Cas.) If 72,385, at 85,148-9 (D.C. Cir. 1968) (concurring opinion); H. Cross, The PEOPLE's Right To KNow 197-247 (1953).

109 See Report of Attorney General's Committee on Administrative Progedure, S. Doc. No. 8, 77th Cong., Ist Sess. 136 (1941). 
authority for the FTC seem weak and questionable. First, by its explicit language, section 6(f) of the FTC Act ${ }^{110}$ obviously is directed either toward public disclosure of information in the Commission's files (not publicity for them) or to publicizing final adjudicative decisions or periodic reports about general industry practices. Second, Congress has made clear, in other contexts, how and when it will authorize pretrial press releases. The leading example is the Federal Food, Drug and Cosmetic Act's authorization to the Secretary of Health, Education and Welfare (who acts through the FDA) to "cause to be disseminated information regarding food, drugs, devices, or cosmetics in situations involving, in the opinion of the Secretary, imminent danger to health or gross deception of the consumer."111 Third, Congress already has granted similar power to the FTG to prevent continued public harm during the pendency of agency hearings where such harm is likely. Specifically, the 1938 Wheeler-Lea Amendment to the FTC Act authorizes a district court to grant temporary injunctions against the dissemination of false advertisements of foods, drugs, cosmetics, and devices pending a final order. ${ }^{112}$ Here it makes sense to find implied if not explicit authority in the FTG to make such orders fully effective by widely disseminated news releases. Fourth, despite numerous appeals by the FTG and consumer groups, Congress has so far refused to extend such injunctive powers to other FTC prosecutions. ${ }^{113}$ In light of this history, congressional silence does not justify the Cinderella court's conclusion that Congress has acquiesced

110 See note 97 supra.

11121 U.S.C. \& 375(b) (1964); see United States v. Diapulse Mfg. Corp. of America, 262 F. Supp. 728 (D. Conn. 1967). See also National Comm'n on Product Safety Act, P.L. 90-146, $\S 3(\mathrm{e})(1) \&(2), 81$ Stat. 466 (1967).

112 FTC Act § 13, 15 U.S.C. § 53 (1964); see FTC v. Sterling Drug, Inc., 317 F.2d 669 (2d Cir. 1963). The anomaly is that this power has been used sparingly. Between 1938 and 1960 the Commission sought temporary injunctions in only 42 cases; it was granted in all but three. Kintner, Federal Trade Commission Regulation of Food, Drug and Cosmetic Advertising, 16 Bus. LAw. 81, 88 (1960). Nor has the Commission's reliance on its preliminary injunctive power increased since 1960. See Weston, Deceptive Advertising and the FTC, 24 FED. B.J. 548, 552 (1964).

The FTC has similar authority to seek preliminary injunctions of violations of the various labeling acts. 15 U.S.C. $\$ \S 68 \mathrm{e}(\mathrm{b}), 69 \mathrm{~g}(\mathrm{~b}), 70 \mathrm{f}(1964) ; 15$ U.S.C. $\$ 1195$ (1964).

113 E.g., S. 3065, 90th Cong., 2d Sess. (1968); H.R. 15339, 15354, 15508, 16156, 90th Cong., 2d Sess. (1968) (Administration bills for a Deceptive Sales Act of 1968); see 114 CoNG. REc. S941 (daily ed. Feb. 6, 1968) (President Johnson's Consumer Protection Message). However, after deleting authority allowing the FTC to seek temporary restraining orders, S. 3065 was passed by the Senate and would amend $\S 13$ of the FTC Act to authorize preliminary injunctions in consumer fraud cases. 114 CoNG. REC. S8502 (daily ed. July 11, 1968). Earlier attempts often sought FTC authority to issue temporary cease and desist orders enforceable in the courts of appeal. See Pewett, Developments in Federal Antitrust Legislation, 28 ABA Antitrust Section 194, 200 (1965); F. Rowe, Price Discrimination Under the RobinsonPatman Act \& 16.13 (1962, Supp. 1964). 
in the FTC's practice of issuing pretrial press releases. ${ }^{114}$ Fifth, even if one accepts the view that some press releases are authorized, the arguments justifying this conclusion generally would not support the present Commission practice of issuing releases on all FTC complaints.

\section{The Exercise of Discretion}

Even if the FTC does have authority to issue press releases upon filing the complaint, as is the apparent judicial conclusion, it does not follow that it necessarily should continue to do so. Several factors converge. What policy should the FTG seek to promote by issuing press releases? Can it be served in alternative ways? How significant are such interests as compared to the injury respondent may suffer from the FTC's use of pretrial press releases? And finally, how should the Commission resolve this conflict?

As we have noted, the justifications offered for the practice of issuing press releases upon filing the complaint vary. ${ }^{115}$ The Commission relies on the need to inform the public of its activities; ${ }^{116}$ this policy apparently is based more on the desire for an informed electorate than on the need to protect the public from the appeal of the charlatan or the deception of the cheat. The courts, on the other hand, have emphasized the purpose of the FTG Act-to protect the public; if the unsophisticated consumer is to be protected, the judicial view is that "it is essential that he be informed in some manner as to the identity of those most likely to prey upon him ...."117 Another reason, acknowledged by FTC staff attorneys, is that such publicity puts pressure on actual or potential agency respondents to comply with the law. ${ }^{118}$

Promotion of public knowledge about agency activities and protection of the public from an immediate danger are unexceptionable policy objectives. Use of pretrial publicity as an in terrorem device to coerce adherence to agency interpretations of unlawful conduct prior to any adjudicative test before the agency, however, seems contrary to the spirit of a fair trial and to the structure of the FTC Act, the FTC Rules and the Administrative Procedure Act. ${ }^{110}$ Congress has already set forth the sanctions it believes appropriate for violations.

\footnotetext{
114 See 1 K.G. Davis, Administrative Law Treatise \$ 5.07 (1958, Supp. 1965).

115 Note, Disparaging Publicity by Federal Agencies, 67 Colum. L. Rev. 1512, 1516-8 (1967).

116 See note 99 supra.

117 FTG v. Cinderella Career \& Finishing Schools, Inc., 5 Trade REg. REP. (1968 Trade Cas.) 72,385 , at 85,146 (D.C. Cir. 1968).

118113 Cong. Rec. A2291 (daily ed. May 9, 1967) (extension of remarks of Rep. Herbert Tenzer); see Note, Disparaging Publicity by Federal Agencies, 67 Colum. L. REv. 1512, 1517 n.26 (1967); cf. Williams, Investigations by the Federal Trade Commission, 29 ABA ANTITRUST Section 71, 78 (1965).

119 Moreover, such coercion may force respondents into acquiescing in questionable
} 
Alternative measures less harmful to private interests-post-trial publicity or release of summaries of Commission activities without specific identification of any respondent-would seem to provide adequate information to the public in its role as electorate. Press releases naming the respondent may be justified only as to those practices concerning which the public requires immediate warning. They should therefore be limited to false advertising and deceptive practice charges under section 5 of the FTC Act and the several fabric and product labeling acts enforced by the FTC. Publicizing a complaint against a respondent whose alleged practice does not create a need for specifically forewarning the public serves no conceivable purpose other than punishment. Moreover, indiscriminate publicity of all FTC complaints deprives the Commission of an effective voice where immediate public notice is needed. After crying "wolf" for so many years, it is not surprising that the FTC's alarms go unheeded by the public. And protection rather than punishment is the only legitimate end of FTC enforcement policy. ${ }^{120}$

The inescapable conclusion seems to be that no legitimate purpose is served by the current FTC practice of issuing press releases in all cases when the complaint is filed; present policies should be changed. The public does not need to be forewarned, for example, that The Stanley Works, a leading producer of hardware products, may have violated section 7 of the Clayton Act by acquiring Amerock Corporation, a national leader in cabinet hardware; ${ }^{121}$ that Koppers Company may have violated section 5 of the FTC Act by monopolizing the production and sale of the chemical resorcinol; ${ }^{122}$ or that others have violated the Robinson-Patman Act. It is true that such publicity probably will not cause substantial or irreparable injury. These charges are commonly the special concern of other businessmen or investors, not the consuming public. And such interested persons are likely to read publications which would ferret out such information from the Commission's public documents whether publicized or not. Publicity of these cases tends to be ignored by the mass media, but this is not always

agency assertions with the additional unfortunate result that new legal theories as well as unfounded factual assertions are neither scrutinized in an administrative trial nor subjected to judicial testing. See Note, Disparaging Publicity by Federal Agencies, 67 Colum. L. Rev. 1517 n.29 (1967).

120 FTC v. Cinderella Career \& Finishing Schools, Inc., 5 Trade REg. REP. (1968 Trade Cas.) If 72,385, at 85,145 (D.C. Cir. 1968); see Ekco Prods. Co., FTC Dkt. No. 8122, [19631965 Transfer Binder] Trade Reg. Rep. I 16,879, at 21,905 (1964); cf. United States v. E. I. duPont de Nemours \& Co., 366 U.S. 316, 326 (1961).

121 FTC Release (May 9, 1968); see Stanley Works, FTC Dkt. No. 8760, 3 TrADE REG. REP. If 18,338 (1968).

122 FTC Release (Jan. 26, 1968); see Koppers Co., FTC Dkt. No. 8755, 3 TRADE REG. REP. If 18,171 (1968). 
the situation. Moreover, the FTC's practice of providing respondent with advance notice so that it can settle or prepare a simultaneous reply, ${ }^{123}$ and the recently adopted policy of adding a cautionary note to each complaint press release ${ }^{124}$ minimizes any possible injury. But lack of probable injury means only that no injunction would issue and respondents are unlikely to seek judicial protection, not that an unwarranted press release practice should continue.

This still leaves open the matter of legitimate FTC press releases. What policy should the FTC adopt for situations in which there is a need to warn the public when the complaint is issued even though that publicity is likely to injure respondent? As the recent tuna fish scares and the famous 1959 cranberry episode demonstrate, agency publicity prior to a final determination on the merits can severely damage respondent by destroying its reputation or cutting off its market, even though respondent is later cleared of all charges. ${ }^{125}$ "Wherever the business success of an agency respondent is dependent upon good public relations, hostile publicity from the agency can pose a great threat -often greater than the threat of official agency sanctions." ${ }^{126}$ On the other hand, there is a powerful public interest in protecting the consuming public from contaminated cranberries, botulism-infected tuna fish, or fraudulent selling practices. And the FTG policy that press releases will not be issued until the complaint is filed provides some protection for private interests since complaints are filed only after investigation reveals substantial cause and respondent has been given an opportunity to settle the case. ${ }^{127}$

123 See FTC Rules § 2.31; Pollock, Pre-Complaint Investigations by the Federal Trade Commission, 9 ANTtrRust Bull. 1, 7-10 (1964).

124 Beginning with the announcement of the Cinderella complaint, the FTC has added the following explanatory note to its pretrial press releases:

(NOTE-A complaint is issued whenever the Commission has found "reason to believe" that the law has been violated and that a proceeding is in the public interest. It is emphasized that the issuance of a complaint simply marks the initiation of a formal proceeding in which the charges in the complaint will be ruled upon after a hearing and on the record. The issuance of a complaint does not indicate or reflect any adjudication of the matters charged.)

FTC Release (March 3, 1967); see School Services, Inc., FTG Dkt. No. 8729 [19651967 Transfer Binder] Trade REg. ReP. If 17,868 (1967).

As a result, the business papers and trade journals often insert the essence of this statement as well as material from respondent's press release in reporting the Commission complaint. See, e.g., Wall Street Journal, Jan. 26, 1968, at 16. However, popular papers do not. See, e.g., New York Times, Jan. 26, 1968, at 82.

125 See, e.g., Sanctions in Silhouette, lecture delivered by $\mathrm{H}$. Thomas Austern at Harvard Law School, March 22, 1960, quoted in W. Gellhorn \& C. Bxse, Administrative Law 671 (4th ed. 1960); Note, Publicity and the Security Market: $A$ Case Study, 7 U. CHr. L. REv. 676 (1940).

126 Note, Disparaging Publicity by Federal Agencies, 67 CoLum. L. REv. 1512, 1515 (1967). 127 See authorities cited supra note 123. 
Perhaps there is no single answer to resolve this problem. ${ }^{128}$ The most appropriate solution from respondent's view, an absolute prohibition on press releases, is too stringent a remedy. Similarly, compensatory relief is unavailable, and if the struggle to obtain compensation for victims of criminal violence is indicative, ${ }^{129}$ is likely to remain so. Current legislative proposals are equally undesirable. One would prohibit agency enforcement of its orders where pre-final order publicity was issued "to discredit or disparage" respondent. ${ }^{130}$ But this leaves the public totally unprotected when protection is most needed-when respondent is engaged in unlawful practices, protects only guilty respondents, and offers no relief to innocent respondents damaged by such publicity. Moreover, agency intent to harm is not necessary to injure a respondent nor does it seem to bear on whether an innocent victim of pretrial publicity should be compensated.

Another suggestion has been to give respondent equal time by permitting judicial modification of an agency order where pre-final order publicity "did discredit or disparage" respondent unless the respondent "has been given an equal opportunity to publicize his comments at the same time and in the same document in which the agency publicity was issued."131 Ironically, this proposal has been criticized for its focus on the effect of adverse publicity rather than on an improper agency purpose ${ }^{132}$ - which in fact seems its strong point if the realities

128 See Note, Disparaging Publicity by Federal Agencies, 67 Colum. L. REv. 1512, 1527 (1967), which observed that "[i]t is indeed rather hard to think of a constructive alternative to the present judicial practice" and suggests that "[t]he greatest contribution Congress can now make to a solution of the press release problem is to do nothing about it." But see Lemove, note 93 supra.

129 E.g., S. 2155, 89th Cong., Ist Sess. (1965); H.R. 11818, 89th Cong., Ist Sess. (1965); see Comment, Compensation for Victims of Crime, 33 U. CHr. L. REv. 531 (1966).

130 S. 518, 90th Cong., 1st Sess $\S 9$ (b) (1967) (proposed amendment of $\S 9$ of the Administrative Procedure Act):

Publicity, which a reviewing court finds was issued by the agency or any officer, employee, or member thereof, to discredit or disparage a person under investigation or a party to an agency proceeding, may be held to be a prejudicial prejudging of the issues in controversy, and the court may set aside any action taken by the agency against such person or party or enter such other order as it deems appropriate.

131 S. 924, 90th Cong., 1st Sess. (1967) (proposed amendment of \& 9(c) of the Adminiistrative Procedure Act):

If a reviewing court finds that publicity which was issued by the agency or any officer, employee, or member thereof, did discredit or disparage a person under investigation or a party to an agency proceeding, that court may hold this to be prejudicial error and may set aside any action taken by the agency against such person or party or enter such other order as it deems appropriate. It shall not be deemed prejudicial error, however, if such person or party has been given an equal opportunity to publicize his comments at the same time and in the same document in which the agency publicity was issued.

132 Note, Disparaging Publicity by Federal Agencies, 67 Colum. L. REv. 1512, 1526 (1967): "If the bill does refer to the effect, rather than the purpose, of agency action, it is an overreaction to the problem it deals with." 
of agency practice are our concern. Yet, this proposal does seem undesirable since it calls additional attention to the issuance of the complaint (the essence of respondent's concern), and if respondent's activities are dangerous or deceptive, the Commission ought not to be a vehicle for promoting such practices by free publicity. (It would not be unheard of, for example, for a respondent to maximize public harm by quoting only that portion of the release which it prepared as indicating FTC approval of its practices.) ${ }^{133}$

But the problem of pretrial publicity is not insoluble. Where probable cause exists that respondent's practices are dangerous or harmful to public health or safety, or are deceptive, but pretrial publicity also may injure an innocent respondent unfairly, the simplest solution would be to minimize respondent's harm and to prevent public injury by giving respondent an option to discontinue the alleged practice pending trial in lieu of the pretrial press release-as if a preliminary court injunction were available. ${ }^{134}$ If the respondent agreed to discontinue the practice, then the Commission would issue no pretrial publicity (just as respondent's answer is unpublicized if requested). It would be preferable if the FTG also were authorized to seek a preliminary injunction in federal court with which this policy could be coordinated since this would eliminate problems concerning agency authority or the effectiveness of respondent's promise. This proposal has the advantage of protecting the public from the challenged practice, of serving the FTC's interests, and of permitting respondent to avoid the harm of adverse publicity. This solution is not perfect. Where the public harm inheres in the product-which is more likely where the FDA rather than the FTG has jurisdiction-respondent may be presented with only a Hobson's choice. But this suggestion seems preferable to current practices or other proposals.

\section{Discovery}

\section{Pre-1961}

Despite considerable pressure, the FTC, like most administrative agencies, has been slow to recognize discovery as an appropriate pre-

133 Cf. Ro-Ed Eng. \& Combustion Co., 28 F.T.C. 1787 (1939); FTC v. Sterling Drug, Inc., 215 F. Supp. 327 (S.D.N.Y.), affd, 317 F.2d 669 (2d Cir. 1963).

134 Precedent for such informal agreements exists in the voluntary compliance program where the Commission foregoes complaint prosecution and its attendant publicity upon receipt of written assurances that the questioned practice has been stopped and will not be resumed. FTC Rules $\$ 2.21$; see, e.g., FTC Release (June 19, 1968) (summary no. 26 of matters closed by assurances of voluntary compliance, not identifying respondents); 1965 FTC ANN. REP. 17-18, 24, 27. See generally Auerbach, The Federal Trade Commission: Internal Organization and Procedure, 48 MINN. L. REv. 383, 429-31 (1964); Note, Voluntary Compliance: An Adjunct to the Mandatory Processes, 38 IND. L.J. 377 (1963). 
trial tool available to respondents in adjudicative proceedings. ${ }^{135} \mathrm{Be}-$ fore 1961, a respondent generally had little or no opportunity to discover complaint counsel's case before trial. (Discovery has always been the special concern of respondents; Commission counsel were seldom interested in the subject except to oppose it because they already had the advantage of the precomplaint investigation and could prepare their cases without further inquiry. ${ }^{136}$ Without discovery, respondent was at a distinct pretrial disadvantage. In preparing his case, the respondent, even though aware of the Commission investigation before the complaint was actually issued, had to rely on its own files or on voluntary disclosures by third parties or the agency. Only during trial could respondent compel the issuance of subpoenas. ${ }^{137}$ This procedure had little to recommend it; it fostered delay, encouraged trial by surprise, limited respondent's ability to detect and expose false claims and arguments, increased the cost of FTC trials, and discouraged pretrial settlements. ${ }^{138}$ Nonetheless, the Commission concluded that

135 As late as 1963, the Administrative Conference concluded that:

Apart from the FAA, and to a more limited extent the FTC, none of these

[1I administrative] agencies with important enforcement powers provides in its

rules for any significant measure of discovery against the agency in administrative adjudicatory proceedings.

S. Doc. No. 24, 88th Cong., Ist Sess. 126 (1963); see Mezines \& Parker, Discovery Before the Federal Trade Commission, 18 AD. L. REv. 55 (Winter-Spring, 1966). See also Manoli \& Joseph, The National Labor Relations Board and Discovery Procedures, 18 AD. L. REv. 9 (Winter-Spring, 1966); Frankhauser \& Belman, The Right to Information in the Administrative Process: A Look at the Securities and Exchange Commission, 18 AD. L. REv. 101 (Winter-Spring, 1966); Maurer, Use of Discovery Procedures Before the C.A.B., 18 AD. L. REv. 157 (Winter-Spring, 1966); Ross, Discovery and the Federal Power Commission, 18 AD. L. REv. 177 (Winter-Spring, 1966); Note, Discovery in Federal Administrative Proceedings, 16 STAN. L. REv. 1035, 1041-58 (1964).

136 See, e.g., Creel, Pre-Trial Discovery and Motions, 14 ABA ANTITrust SEction 23, 27-28, 31 (1959); Hier, Pre-hearing Procedures at the Federal Trade Commission, 11 AD. L. BuLl. 139, 142, 143 (1958).

137 The report of the Administrative Conference summarized the inadequacy of volun. tary disclosure:

This is not to deny the truth of the frequent agency assertion that in fact they voluntarily provide more information from their files than is required by their rules. The difficulty remains, however, that where there is no regularized way of securing data, except within agency discretion, complaints of unfairness will be made, no mater how ill-founded in fact.

S. Doc. No. 24 , supra note 135 , at 132 . See also S. Doc. No. 248 , 79th Cong., 2 d Sess. 27 (1945) (legislative history of $\S 6(c)$ of the APA).

138 See Report of President's Conference on Administrative Procedure, 37, $71-72$ (1953); I K.C. Davis, Administrative LAw Treatise $\$ 8.15$, at 589 (1958) ("Probably no sound reason can be given for failure to extend to administrative adjudications the discovery procedures worked out for judicial proceedings."); Berger, Discovery in Administrative Proceedings: Why Agencies Should Catch Up With the Courts, 46 A.B.A.J. 74 (1960); Kaufman, Have Administrative Agencies Kept Pace With Modern Court-Developed Techniques Against Delay? - A Judge's View, 12 AD. L. Bull. 103 (1960); Howrey, The Federal Trade Commission-Present Problems and Suggested Changes, 10 ABA ANTITRusr SEcmion 40, 44 (1957); cf. 4 J. Moore \& B. Garfinkel, Federal Practice f 26.02[2] (2d ed. 1967); Developments in the Law-Discovery, 74 HARv. L. REv. 940, 944-6 (1961). 
respondent was not unfairly disadvantaged; under the interval hearing procedure continuances were readily granted to permit preparation of respondent's case or to prepare for cross-examination of complaint counsel's witnesses. ${ }^{139}$ Moreover, FTC rules did permit the taking of depositions and interrogatories upon a showing of "good cause."140 In reality, however, such discovery was limited to preserving testimony, ${ }^{141}$ although hearing examiners occasionally exercised their discretion to permit information-gathering discovery. ${ }^{142}$ At best, then, FTC proceedings were languorous affairs; at their worst respondent was at a distinct disadvantage and a generation could pass between the FTC's filing of a complaint and the final order. ${ }^{143}$

But the FTC's refusal to give general recognition to pretrial discovery was not the only hurdle in the way of respondent's obtaining agency-held information. Restrictive confidentiality policies were equally troublesome obstacles. Before passage of the Administrative Procedure Act in 1946, administrative secrecy commonly went so far as to make it difficult to ascertain "even such nonsecret fundamentals as agency organization, immediate and ultimate sources of authority, and such absolute essentials as the procedural and substantive rules governing agency action." 144 Loosening of these shackles by the APA did not open the gates to a flood of pretrial information, however, and the agencies' conclusion that discovery is not required by the APA has been sustained. ${ }^{145}$ In addition, the FTC (and other agencies) protected evidentiary files on grounds that across-the-board confidentiality was necessary to assure the integrity of the administrative process and that

139 E.g., Joseph A. Kaplan \& Sons, Inc., 57 F.T.C. 1537, 1539 (1960); see Standard Distribs., Inc. v. FTC, 211 F.2d 7, 11 (2d Cir. 1954). But see Pacific Molasses Co. v. FTC, 356 F.2d 386, 390 (5th Cir. 1966), rev'g FTC Dkt. No. 7462 [1963-1965 Transfer Binder] Trade Reg. REP. I 16,916 (1964).

140 FTC Rules \$ 3.12(a), 20 Fed. Reg. 3063 (1955).

141 See id. § 3.12(d), 20 Fed. Reg. 3063-4 (1955); Joseph A. Kaplan \& Sons, Inc., 57 F.T.C. 1537 (1960); American News Co., FTC Dkt. No. 7396 [1959-1960 Transfer Binder] TradE REG. REP. If 28,178 (1959).

142 See Gulf Oil Corp., 54 F.T.C. 1891 (1958); American Metal Prods. Co., FTG Dkt. No. 7365 [1959-1960 Transfer Binder] Trade REg. REP. If 28,173 (1959).

143 See Connor, FTC Procedure Revisions: A Critique, 7 Vnu. L. REv. 359, 378-80, 384-8 (1962). The most extreme example of delay-part of it the result of court litigation rather than agency proceedings-is Carter Prods., Inc. v. FTC, 268 F.2d 461 (9th Cir.), cert. denied, 361 U.S. 884 (1959), where it took the FTC 15 years to get the "Liver" out of "Carter's Little Liver Pills."

144 S. Doc. No. 24, supra note 135, at 123; see Note, The Federal Register and the Code of Federal Regulations: A Reappraisal, 80 HARv. L. REv. 439 (1966); Newman, Government and Ignorance-A Progress Report on Publication of Federal Regulations, 63 HARv. $\mathrm{L}$. REV. 929 (1950).

145 S. Doc. No. 24, supra note 135 , at 123-32. 
the data were within work product or other privileges. ${ }^{148}$ In other words, disclosure was a matter for agency discretion rather than of respondent right.

\section{Post-1961}

This framework of no pretrial disclosure of information to a respondent in an FTC adjudicative proceeding has changed. In connection with pretrial discovery the change has been revolutionary. By comparison the change in confidentiality policies has been evolutionary.

Discovery policies had to be revised when the oft-interrupted adjudicative hearing became the exception in Commission practice upon the FTG's adoption in 1961 of the judicial rule of continuous hearings. ${ }^{\mathbf{1 4 7}}$ Pretrial discovery became a question of fairness rather than FTC discretion. ${ }^{148}$ Prehearing conferences were made mandatory in almost all cases. ${ }^{149}$ After experimenting with several tests, the Commission now approves (at least temporarily) of pretrial discovery depositions if the examiner concludes that they are necessary for development of respondent's case and will not cause unreasonable delay. ${ }^{150}$ Pretrial discovery

146 See FTC Rules § 1.138, 20 Fed. Reg. 3059-60 (1955); id. § 1.163, 27 Fed. Reg. 4614-5 (1962); id. § 1.133, 28 Fed. Reg. 7085 (1963); L. G. Balfour Co., FTC Dkt. No. 8435 [19611963 Transfer Binder] Trade Reg. REP. If 16,423, at 21,294 (1963); Shell Oil Co., 62 F.T.C. 1488 (1963). See also Giant Food, Inc., 58 F.T.C. 1193 (1961); Libbey-Owens-Ford Glass Co., 56 F.T.C. 1661 (1960); Thomasville Chair Co., 56 F.T.C. 1651 (1959); Pure Oil Co., 54 F.T.C. 1892 (1958); Postal Life \& Cas. Ins. Co., 52 F.T.C. 651 (1956).

147 FTC Rules § 4.14(d), 26 Fed. Reg. 6019 (1961), now FTC Rules § 3.41(b); see Universe Chemicals, Inc., FTC Dkt. No. 8752, 3 TRADE REG. Rep. IT 18,253, 18,310 (1968); Thermochemical Prods., Inc., FTC Dkt. No. 8725, 3 TRADE Reg. REP. If 18,062 (1967).

148 E.g., Topps Chewing Gum, Inc., FTC Dkt. No. 8463 [1963-1965 Transfer Binder] TRADE REg. REP. I 16,471 (1963); Connor, FTC Procedure Revisions: A Critique, 7 VuL. L. REv. 359, 378 (1962) ("full disclosure is almost a requisite for a fair hearing now that 'trial by interval' has been abolished").

140 FTC Rules § 4.8, 26 Fed. Reg. 6017 (1961) (prehearing conference mandatory where hearing likely to last more than three days, otherwise at examiner's discretion), now FTC Rules $\S 3.21$ (a) (a five day test).

150 FTC Rules \& 3.33; Koppers Co., FTC Dkt. No. 8755 (Interlocutory Remand Order, July 2, 1968). See generally Kintner, Recent Changes in Federal Trade Commission Discovery Practice, 37 ANTrrRusr L.J. 238 (1968); Stewart \& Ward, FTC Discovery: Depositions, The Freedom of Information Act and Confidential Informants, 37 ANTrTRusr L.J. 248 (1968); Mezines \& Parker, Discovery Before the Federal Trade Commission, 18 AD. L. REv. 55, 59-67 (Winter-Spring, 1966).

Although the Commission at first retained the "good cause" limitation on taking depositions, which it had previously followed under the interval-type hearing procedure (see authorities cited notes $140 \& 141$, supra), it reinterpreted "good cause" as being satisfied by " $a$ showing of the relevance and usefulness for defensive purposes of the information sought and of the need for eliciting it by deposition rather than by testimony at the hearings ...." Topps Chewing Gum, Inc., supra note 148. When this test produced confusion and a deluge of discovery appeals to the Commission, the FTC dropped the "good cause" limitation and authorized examiners to grant the taking of depositions when respondent demonstrated that the deposition would "constitute or contain evidence" without being 
subpoenas to obtain documents, much in the manner provided in Rules 34 and 45 of the Federal Rules of Civil Procedure, were also made available to respondent. ${ }^{151}$ And pretrial admissions of facts or exhibits also can be sought. ${ }^{152}$ The Commission recently summarized its discovery rules as follows:

The rules for adjudicatory proceedings are intended to embody the Commission's conviction that, to the fullest extent practicable, the strategy of surprise and the art of concealment will have no place in a Commission proceeding. Hence, we have also provided for thorough postcomplaint discovery procedures. It should be obvious that discovery is a two-way street and that it is the hearing examiner's responsibility to insist that both complaint counsel and respondent's counsel be provided with sufficient data to insure an expeditious and completely fair hearing. ${ }^{153}$

unduly burdensome or causing unreasonable delay. FTC Rules \& 3.10, 28 Fed. Reg. 7088 (1963). Although hailed as authorizing purely discovery depositions, a literal interpretation was suggested by the Commission. Compare Dixon, Significant New Commission Developments, 23 ABA ANTITRust Section 50, 58-9 (1963), with Kintner, Discovery in Administrative Adjudicative Proceedings, 16 Av. L. REv. 233, 241 (1964). See Topps Chewing Gum, Inc. v. Tocker, 1963 Trade Cas. If 70,932 (D.D.C.); Note, Discovery in Federal Administrative Proceedings, 16 Stan. L. REv. 1035, 1050 n.83 (1964). But see American Brake Shoe Co., FTC Dkt. No. 8622 [1965-1967 Transfer Binder] TRADE REG. REP. II 17,318, 17,395 (1965). Then, effective July 1, 1967, the Commission dropped this "evidence" test and authorized depositions shown to be "necessary for purposes of discovery" which "could not be accomplished by voluntary methods." FTC Rules § 3.33. Again, former FTC chairman Kintner hailed these new rules as recognition by the Commission "[f]or the first time ... . that depositions may be taken for discovery purposes." Kintner, Recent Changes in Federal Trade Commission Discovery Practice, supra at 239. Others have pointed out, however, that the requirement of a showing of necessity and unavailability of other methods for obtaining the information as well as the direction that hearing testimony not be duplicated by deposition, "if literally construed, reverses the trend in the direction of the civil rules and may well have a 'chilling effect' upon the taking and use of depositions." Stewart \&. Ward, supra at 249; see Associated Merchandising Corp., FTG Dkt. No. 8651, 3 TradE REc. REP. I 18,102 (1967). This time Mr. Kintner's optimism was justified. Koppers Co., supra; see All-State Indus., Inc., FTC Dkt. No. 8738, 3 Trade REg. REP. I 18,103 (1967), quoted in text accompanying note 153 infra; Lehigh Portland Cement Co., FTC Dkt. No. 8680, 3 TRADE REG. REP. I 18,265 (1968).

151 Section 3.11 of the 1963 rules provided for production of documents in the manner of Rule 34 of the Federal Rules. FTG Rules $\$ 3.11,28$ Fed. Reg. 7088 (1963). Section 3.34 of the 1967 rules providing for discovery subpoenas supplants this provision-and extends the former subpoena rule (FTC Rules $\$ 3.17,28$ Fed. Reg. 7089-90 (1963)) by authorizing "the fullest and most complete discovery practicable" through the use of subpoenas similar to Rule 45 of the Federal Rules. FTC Rules \$ 3.34; Lehigh Portland Cement Co., FTC Dkt. No. 8680, 3 Trade REg. REP. I 18,265 (1968); All-State Indus., Inc., FTG Dkt. No. 8738, TRADE REg. REP. I 18,103 (1967); see Dean Foods Co., FTC Dkt. No. 8674 [1965-1967 Transfer Binder] Trade Reg. ReP. I 17,521 (1966); cf. R. H. Macy \& Co., FTC Dkt. No. 8650 [1965-1967 Transfer Binder] TRADE REg. REP. I 17,344 (1965). The current deposition rule also provides for the production of documents. FTC RULES $\S 3.33$.

152 FTC Rules \$ 3.31 .

153 All-State Indus., Inc., FTC Dkt. No. 8738, 3 TrAdE REG. REP. I 18,103, at 20,550 
The coordinate development of FTG confidentiality policies during discovery cannot be summarized so succinctly.

\section{Reaching the Question of Confidentiality}

Confidential treatment may be sought in various contexts at the discovery stage of FTC proceedings, and the context invariably affects and often determines the protection afforded. Discovery can be engaged in by Commission counsel or respondent; confidentiality may require special treatment, nondisclosure, or limited disclosure.

Discovery by the FTC. When the FTC engages in discovery to "round out, extend, or supply further details"154 for complaint counsel's case, the issue of confidentiality is indistinguishable from the FTC's acquisition of information in nonpublic investigations and its disclosure of sensitive data at adjudicative hearings. The Commission's post-complaint discovery power is as broad-and as unaffected by the sensitivity of the data-as its precomplaint investigative authority. ${ }^{155}$ Until the information is offered into evidence at the adjudicative hearing or is required for effective prehearing conference exchanges, the statutory requirement (reinforced by Commission rule) that trade secrets be kept confidential and that information in government files not be disclosed except when authorized by the Commission, must be met. ${ }^{156}$ Nor were these restrictions removed by the recent amendment of section 3 of the APA. ${ }^{157}$ On the other hand, hearing examiners now commonly require that parties exchange witness lists and copies of all exhibits before trial. ${ }^{158}$ Such disclosure, shortly before trial or at the

(1967) (footnote omitted); see id., 3 Trade REg. REP. I 18,503 (1968) (Supplemental and Clarifying Opinion); Crown Cork \& Seal Co., FTC Dkt. No. 8687 (Interlocutory Order Feb. 8, 1967) (Elman dissenting).

154 All-State Indus., Inc., FTC Dkt. No. 8738, 3 Trade Reg. Rep. I 18,103, at 20,550 (1967) (italics omitted); Marlo Furniture Co., FTC Dkt. No. 8745, 3 TradE REg. REP. I 18,268 (1968); Curtiss-Wright Corp., FTC Dkt. No. 8703, 3 TRADE REg. REP. If 18,133 (1967).

155 See Menzies v. FTC, 242 F.2d 8I (4th Cir. 1957); FTC v. Waltham Watch Co., 169 F. Supp. 614, 620 (S.D.N.Y. 1959) (dictum). See also Kaiser Indus. Corp., FTC Dkt. No. 8341 [1961-1963 Transfer Binder] Trade Reg. Rep. If 15,765 (1962). But see United States v. Assoc. Merchandising Corp., 261 F. Supp. 553 (S.D.N.Y. 1966). The FTC's limitation of complaint counsel's discovery prerogatives, therefore, is discretionary.

156 See authorities cited supra notes 68 \& 76; FTC v. Tuttle, 244 F.2d 605, 616 (2d Cir.), cert. denied, 354 U.S. 925 (1957).

1575 U.S.C. § 552(b)(3)-(5) (Supp. III, 1968); see Attorney General's Memorandum on the Public Information Section of the Administrative Procedure Act 31-6 (1967). See also Staff of Special Subcommittee on Government Information of House Committee on Government Operations, 86th Cong., 2d Sess., Federal Statutes on the Avallability of InFormation (Comm. Print 1960).

158 FTC Rules § 3.21(a)(6); see, e.g., L.G. Balfour Co., 62 F.T.C. 1541, 1544 (1963); American Metal Prods. Co., FTC Dkt. No. 7365 [1959-1960 Transfer Binder] TRADE REG. REP. I 28,173 (1959); Gulf Oil Corp., 54 F.T.C. 1891 (1958); cf. American Metal Prods. Co., 58 F.T.C. 1165 (1961). 
prehearing conference, logically comes within the treatment of confidential information at the adjudicative hearing; that is, the burden should be on the person proposing confidentiality, and considerations governing whether confidential treatment is warranted at the hearing are applicable. This is so since the only difference between these prehearing disclosures and those at trial is the timing, which has been pushed forward to expedite the actual trial. ${ }^{159}$

The remaining difficult and essentially unresolved problems of confidentiality during FTC discovery are: (1) Has the third party supplying the confidential information been given notice of the public disclosure (so that it can request confidential treatment)? (2) Does the information warrant confidential treatment at trial and hence during pretrial? (3) What are the appropriate safeguards? These questions have been considered elsewhere. ${ }^{160}$

Discovery by the Respondent. Discovery by complaint counsel is the exception rather than the rule, since the government's case is generally completed during the investigative stage. Thus, the primary questions of confidentiality at the pretrial stage occur during discovery initiated by respondents. They seek information from other private parties or third persons, from FTG files and personnel, and from other government departments.

In contrast to discovery by complaint counsel, discovery by respondent may raise questions of confidentiality at the time the request for discovery is presented or enforcement of the request is sought. ${ }^{161}$ Private parties commonly object to discovery because they are respondent's competitors and do not want to supply competitive information, trade secrets, or other sensitive data under the guise of discovery.

159 Cf. Topps Chewing Gum, Inc., FTC Dkt. No. 8463 [1961-1963 Transfer Binder] TRAde Reg. Rep. If 16,438 (1963) (Hearing Examiner Order).

160 See Gellhorn 408-23. Several of the measures proposed there to test and treat confidential material have recently been adopted by the FTC. See Lehigh Portland Cement Co., FTC Dkt. No. 8680, 3 Trade Reg. ReP. I 18,475 (1968); Koppers Co., FTC Dkt. No. 8755 (Interlocutory Order Aug. 14, 1968); id. (Hearing Examiner Order, Sept. 4, 1968); id., 3 TRADE REG. REP. If 18,577, at 20,919 (Interlocutory Order, Nov. 1, 1968); see also Cohn \& Zuckman, FCC v. Schreiber: In Camera and the Administrative Agency, 56 Geo. L.J. $451,462-4$ (1968).

161 Except for written requests for admission of facts or documents, all requests for discovery in FTC proceedings must be made to the hearing examiner who determines whether they are justified. FTC Rules $\S \S 3.31-35$. The notice procedure governing discovery under the Federal Rules of Civil Procedure was adopted by the FTC only for admissions. Id. § 3.31. However, application for discovery to the examiner "may be made ex parte and, if so made, such applications and the rulings thereon shall remain ex parte unless otherwise ordered by the hearing examiner or the Commission." Id. § 3.35(a); see Lehigh Portland Cement Co., FTC Dkt. No. 8680, 3 Trade REg. ReP. If 18,322 (1968). But see Kintner, Recent Changes in Federal Trade Commission Discovery Practice, 37 ANTITRUST L.J. 238, 242 (1968). 
When respondent's request is made of the FTC, other interests collide. The Commission needs to protect informants in order to keep its channels of communication open with cooperating businessmen or to honor confidences established in acquiring the information. FTC files may contain the confidential business information of third persons or of respondent's competitors; disclosure could seriously disadvantage them and unjustly advantage respondent, the asserted law-breaker. It would be anomalous, indeed, if an FTC finding of "reason to believe" that respondent was violating the law (even though made as a result of an ex parte proceedings) were to become respondent's license to obtain competitive information without fear of self-disclosure. ${ }^{162}$ Moreover, FTG's files may be privileged as the work product of complaint counsel or as recording the internal workings and thought processes of the agency; disclosure might inhibit such endeavors.

Whatever the justification for confidentiality, it is apparent that the question of disclosure or special treatment of this information arises immediately upon respondent's discovery request. ${ }^{163}$ The issue of whether the data is sensitive - at least as to disclosure to respondentcannot be postponed. In addition, if respondent's discovery is accomplished by deposition, the transcripts are public when filed with the hearing examiner; 164 in this instance the question of confidentiality includes not only disclosure to respondent but also opening this information to the public.

162 Even though current FTC Rules limit consent negatiations generally to precomplaint proceedings (FTG Rules $\$ 2.34(\mathrm{~d})$ ), unless discovery is restricted or disclosure is prevented by confidentiality policies, respondent could use FTC discovery to ferret out its competitors' secrets and then accept a cease and desist order to avoid self-disclosure.

163 See, e.g., Mississippi River Fuel Corp., FTC Dkt. No. 8657 (June 8, 1966) (unreported decision); id. [1965-1967 Transfer Binder] TRADE REg. REP. $\uparrow$ 17,612 (1966) (order denying petition for reconsideration).

164 Topps Chewing Gum, Inc., FTC Dkt. No. 8463 [1963-1965 Transfer Binder] TrAdE REg. REP. 16,438 (Hearing Examiner Order 1963), reported in full in 14 AD. L.2d 161. This ruling may no longer govern pretrial discovery, however. In Topps the examiner relied upon the "open door" policy of public disclosure adopted by the Commission for adjudicatory proceedings in H. P. Hood \& Sons, Inc., 58 F.T.C. 1184 (1961), but FTC discovery now may be used for "pure" discovery in addition to evidentiary purposes. See note 150 supra. Thus, decisions of confidentiality during an adjudicative hearing do not necessarily guide pretrial disclosure policy. Moreover, in Crown Cork \& Seal Co., FTC Dkt. No. 8687, at 3 (April 10, 1967) (slip opinion), the examiner indicated that sensitive data produced pursuant to an FTC subpoena "would be kept confidential prior to [its] introduction into evidence and at the time of introduction he would consider whether to grant in camera status . . . ." See National Dairy Prods. Corp., FTC Dkt. No. 8548 [19631965 Transfer Binder] Trade Reg. Rep. \ 16,778 (1964); accord, Koppers Co., FTC Dkt. No. 8755 (Hearing Examiner Order July 9, 1968): "The transcripts of the depositions shall not be filed in the public record pending 10 days notice to counsel for . . . [third party deponents] so that he may move for a protective order . . . ." Where complaint counsel is the requesting party there is no problem because until the documents "are offered in 


\section{The Power to Decide}

There apparently has never been any doubt that FTG hearing examiners are authorized to determine initially whether discovery of confidential information in private hands should be ordered and protective procedures required. ${ }^{165}$ Aggrieved parties or witnesses do have recourse by interlocutory appeal to the Commission to overturn an examiner's abuse of discretion, ${ }^{168}$ and, if unsuccessful, to a district court to prevent irreparable injury. ${ }^{167}$ But, as the FTC has liberalized its discovery process, it has also expanded the scope of the examiner's discretion, and the objecting party now has a heavy burden to carry if it seeks to reverse an examiner's discovery decision. ${ }^{168}$

Until recently, this simple, orderly procedure did not govern respondent's request for information from FTC files (including complaint counsel's files). As if seeking to confirm the layman's impression of the administrative process, the Commission first created chaos and then labored long to restore order and predictability to its confidentiality policies. The FTC's extraordinary difficulties in deciding who should decide whether and under what conditions, if any, the information could be released to respondent, illustrate this point. Even though the new FTG Rules issued on May 1 have now simplified matters, this

evidence or returned to respondents, counsel supporting the complaint will be subject to the requirements of statute and Commission Rule that he treated them as confidential." Graber Mfg. Co., FTC Dkt. No. 8038 [1961-1963 Transfer Binder] Trade Reg. Rep. If 15,830 (1962) (Hearing Examiner Order). This promise was inadequate for a district court, however, which conditioned enforcement of the FTC subpoena on in camera treatment of respondent's sales figures. Graber Mfg. Co. v. Dixon, 223 F. Supp. 1020 (D.D.C. 1963). See FTC v. Continental Can Co., 267 F. Supp. 713 (S.D.N.Y. 1967) (requiring in camera assurance in advance of production in Crown, supra). Thus, the Commission has occasionally ordered complaint counsel and his expert witnesses to hold sensitive data in confidence. Koppers Co., FTC Dkt. No. 8755, 3 TRADE REG. REP. I 18,329 (1968).

165 See, e.g., FTC Rules \$ 3.34; id. § 3.17, 28 Fed. Reg. 7089-90 (1963); Crown Cork \& Seal Co., FTC Dkt. No. 8687 [1965-1967 Transfer Binder] Trade REg. REP. I] 17,828 (1967); Mississippi River Fuel Corp., FTC Dkt. No. 8657 (Interlocutory Opinion, June 8, 1966); id. [1965-1967 Transfer Binder] TRADE Reg. ReP. I 17,612 (1966) (reconsideration of June 8 order denied).

108 FTC Rules § 3.35(b); see Crown Cork \& Seal Co., FTC Dkt. No. 8687 [1965-1967 Transfer Binder] Trade REg. Rep. I 17,828 (1967); General Transmissions Corp., FTC Dkt. No. 8713 [1965-1967 Transfer Binder] Trade Reg. Rep. $₫$ 17,813 (1966); American Brake Shoe Co., FTG Dkt. No. 8622 [1965-1967 Transfer Binder] Trade Rec. Rep. I 17,318 (1965); Topps Chewing Gum, Inc., FTC Dkt. No. 8643 [1963-1965 Transfer Binder] TradE REG. REP. If 16,471 (1963).

167 E.g., Sperry \& Hutchinson Co. v. FTC, 256 F. Supp. 136, 140-1 (S.D.N.Y. 1966); R. H. Macy \& Co. v. Tinley, 249 F. Supp. 778, 782-3 (D.D.C. 1965); see FTC v. Continental Can Co., Inc., 267 F. Supp. 713 (S.D.N.Y. 1967)

168 Eg., All-State Indus. Inc., FTC Dkt. No. 8738, 3 Trade REg. REP. 1 18,103, at 20,550 n.4 (1967); Graber Mfg. Co., FTC Dkt. No. 8038 [1965-1967 Transfer Binder] Trade REG. REP. I 17,409, at 22,617 (1965). 
story, which has a Never-Never Land character, needs telling in order to understand and evaluate substantive confidentiality rulings and, perhaps, to discourage its repetition.

The 1961 FTC Rules continued the Commission's prior practice of presuming that almost all information in FTC files was confidential and should be released only upon a showing of "good cause."160 The rules provided that "the Commission may order" disclosure upon receipt of "an application" requesting release of the information from the Commission's files. Earlier interpretations had held that the examiner had no authority to release Commission files; thus, applications apparently were to be made directly to the full Commission. ${ }^{170}$ The only express exception in the rules involved prehearing conference disclosures. ${ }^{171}$ This rule, new in 1961, codified a long-established practice of FTC examiners to require complaint counsel to divulge the names of his witnesses and provide copies of all intended exhibits to respondent in advance of the hearing. ${ }^{172}$ Then, in L.G. Balfour Co., ${ }^{173}$ the FTC reaffirmed the general policy of requiring Commission approval for all releases of file information, but added that the application for release was to be made by respondent to the examiner who was to

169 FTC Rules $\S \S 1.133-.134,20$ Fed. Reg. 3059-60 (1955) (in effect in 1961); see Giant Food, Inc., 58 F.T.C. 1193, 1194 (1961).

In tracing the development of FTC confidentiality procedure at the discovery stage, the various rule references in the cases are confusing until it is noted that the rule numbers and contents have been changed often. In 1962 they were renumbered but not otherwise changed (as §§ 1.163-.164); then in 1963 their earlier numbers were restored but the decision procedure was altered. 27 Fed. Reg. 4609 (1962); 28 Fed. Reg. 7080 (1963). The rules were renumbered, their contents altered, and the discovery portion separated from general confidentiality rules again in 1967. FTC Rules $\$ \S 3.36,4.10-11,32$ Fed. Reg. 8452, 8459 (1967). Finally, their content and decision procedure were altered once again effective May 25, 1968. FTC Rules §§ 3.36, 4.11(d), 33 Fed. Reg. 7033 (1968).

170 Interpreting $\S 1.134$ in Postal Life \& Cas. Ins. Co., 52 F.T.C. 651, 653 (1956), the Commission held:

No other method for obtaining the release of confidential information is provided for in the rules. It follows that the hearing examiner has no authority to require the production of information or material from the Commission's files by a subpoena duces tecum or otherwise.

Accord, Thomasville Chair Co., 56 F.T.C. 1651, 1652 (1959).

171 [The prehearing conference may consider] matters as may aid in the orderly disposition of the proceeding, including disclosure of the names of witnesses or furnishing for inspection or copying of non-privileged documents, papers, books or other physical exhibits, which constitute or contain evidence relevant to the subject matter involved and which are in the possession, custody or control of any party to the proceeding.

FTC Rules $\S 4.8(a)(5), 26$ Fed. Reg. 6017 (1961) (emphasis added).

172 See authorities cited note 158 supra.

17361 F.T.C. 1491 (1962); 62 F.T.C. 1541, 1545 (1963). The procedure had been suggested in Union Bag-Camp Paper Corp., FTC Dkt. No. 7946 (Interlocutory Order July 30, 1962), but as happens so often with procedural decisions of the FTC it does not appear to have been reported. See also Shell Oil Co., 62 F.T.C. 1488 (1963). 
"recommend" whether "good cause" had been demonstrated and then certify the application to the Commission, which would determine the question de novo. ${ }^{174}$

This cumbersome and time-consuming procedure, which emphasized the Commission's apparent mistrust of its hearing examiners, was followed woodenly. The examiner was not entrusted with authority to order disclosure of FTG files even when, as in Balfour, the documents sought were originally obtained by the Commission from respondent's very own files and confidentiality was due solely to their location and not their contents. ${ }^{175}$

On the other hand, it was not clear that this duplicative procedure had to be followed in every instance since the rules also provided for discovery without regard to the location or custody of the documents or information. ${ }^{176}$ If these discovery rules were exclusive of the confidentiality rules, as some argued, respondent's burden of proof for disclosure, especially after the 1963 rules change, would be lightened considerably. Instead of having to show "good cause" for the release of FTG files, it would need to demonstrate only that the request sought relevant documents or testimony and was specific and reasonable in scope, ${ }^{177}$ thereby entirely avoiding the question of confidentiality and its test of good cause.

This conflict between the rule protecting FTG files and that granting discovery to respondents arose indirectly in Furr's, Inc. ${ }^{178}$ when respondent sought clarification of its right to discover documents which complaint counsel might put into evidence. Although the Commission remanded the case to the examiner with the admonition that docu-

174 In matters of this sort, the examiner's recommendation, because he is closer to the issues involved in the proceeding, is entitled to considerable weight. . . . Nevertheless, the Commission cannot substitute his judgment for its own particularly where, in the opinion of the Commission, he is not wholly correct. The responsibility for release of confidential material is confided under the Rules to the Commission itself.

Crown Cork \& Seal Co., FTC Dkt. No. 8687, at 4 (Interlocutory Opinion Feb. 8, 1967) (unreported slip opinion).

175 L.G. Balfour Co., 62 F.T.C. 1541 (1963). See also L.G. Balfour Co., FTC Dkt. No. 8435 [1963-1965 Transfer Binder] TRADE REg. REP. If 16,635 (1963).

This procedure, moreover, introduced a double standard in the enforcement of merger law under $\S 7$ of the Clayton Act. In FTC proceedings respondent had to show not only that documents in FTC files were not privileged but also that "good cause" supported disclosure; whereas if the action had been brought by the Justice Department, discovery would have been granted automatically in these circumstances. See, e.g., Crown Cork \&: Seal Co., FTC Dkt. No. 8687 (Interlocutory Opinion Feb. 8, 1967) (unreported dissenting opinion).

176 See notes 150 \& 151 supra.

177 E.g., Topps Chewing Gum, Inc., FTC Dkt. No. 8463 [1963-1965 Transfer Binder] Trade Reg. REP. I 16,471, at 21,341 (1963).

178 FTC Dkt. No. 8581 (Interlocutory Order Nov. 18, 1963) (unreported opinion). 
ments admissible in the adjudicative hearing on the public record should not be protected during discovery, it was arguable that since the Commission had not specifically limited its ruling to documents intended as FTC exhibits, it had implicitly held that a hearing examiner could order production of documents in complaint counsel's possession without other authority from the Commission under his powers to grant discovery. This interpretation, however, conflicted with dicta in Balfour, decided just half a year earlier, that, aside from the limited prehearing exception, the only manner in which confidential information could be released from FTG files was by the Commission application route. ${ }^{178}$

It was not until the Commission's decision in R.H. Macy \& Co., 180 almost two years later, that this question was resolved by a ruling that discovery rules were subordinate to confidentiality policies and that the rules were not in pari materia. This meant that if respondent was to obtain information in complaint counsel's files it had to satisfy both the discovery rules and the good cause requirement of the confidentiality procedure.

Confusion in the FTC bar and the opportunities for delay established by this two-step procedure resulted in numerous discovery and confidentiality appeals to the Commission. As a result, the Commission rewrote its confidentiality procedures three months after its second Balfour decision, which had sought to clarify and spell out the required procedure. The new rule added an exception to the Commissiondisclosure route:

Except to the extent that disclosure of such material or information is specifically authorized by the Commission or to the extent that its use may become necessary in connection with adjudicative proceedings, [confidential FTC files] may be disclosed, divulged, or produced ... only under the procedure [outlined in the rules and spelled out in Balfour]. . . . .181

Instead of clarifying the procedure for obtaining a ruling on the release of FTC files, this new rule further confused the issue. ${ }^{182}$ First,

179 L.G. Balfour Co., 62 F.T.C. 1541, 1545 (1963).

180 FTC Dkt. No. 8650 [1965-1967 Transfer Binder] Trade REg. REP. If 17,344 (1965). Respondent had sought to subpoena internal Commission memoranda relating to its investigation of respondent while, at the same time, it asked for subpoenas ad testificandum of three staff employees. The Commission held that since both requests were designed to elicit the same information, the motions were to be disposed of in accordance with the rules governing confidential information.

181 FTC Rules \& 1.133(a), 28 Fed. Reg. 7085 (1963) (emphasis added).

182 This confusion is reflected in the comments of one examiner during oral argument on a discovery motion:

I would like to see the question resolved as to what we're going to consider 
what material was "specifically authorized by the Commission" to be released? Did this include information discoverable under FTC rules without limitation as to location or custody? Second, what information was "necessary" for respondent's case? Did necessity include information generally helpful to respondent's case? Under this two-fold exception the focus shifted from showing good cause (to the Commission's satisfaction) to convincing the examiner that he was authorized to release the information because it was either specifically authorized or necessary. The Commission's confidentiality caseload was not reduced.

Apparently, no case directly considered the first-"specifically authorized"-exception. Perhaps the argument that it encompassed all discoverable information was too strained even for inventive antitrust practitioners. In any case, as noted previously, the Commission's Macy decision had dispelled any notion that information within the scope of FTC discovery rules might be within the ambit of the first exception. The "specifically authorized" exception appeared to be limited to prehearing conference disclosures and to material such as Jencks-type statements which the Commission had previously ruled could be disclosed by an examiner's order. ${ }^{183}$ Thus, the first branch of the exception added nothing to prior practice.

The scope of the necessity exception-information in FTC files "necessary in connection with adjudicative proceedings"-proved more perplexing. It seemed significant that this exception was adopted as part of a rules reform separating prehearing conference functions from discovery. Conference disclosure was limited to documents to be "introduced in evidence" because discovery was expanded to include documents or information which "constitute or contain evidence relevant to the subject matter involved." 184 Reading these rule changes together, it seemed clear that the examiner should order information released from FTC files if he was satisfied that it was "necessary" for develop-

confidential files. That is everything that is not offered, is this a part of the confidential file and if per se [it] is confidential because it is in the confidential file. It doesn't seem to me the Commission can intend this.

Seeburg Corp., FTC Dkt. No. 8682, Transcript at 2050, as quoted in Respondent's Request for Plenary Consideration by the Commission of Certification by the Hearing Examiner Concerning Commission Policies as to Confidential Files, Seeburg Corp., at 3, filed Feb. 2, 1967. However, the question was not ruled upon by the Commission in this case. For a history of this skirmish, see Gellhorn 427 n.141.

183 See notes 171 \& 172 supra; Sun Oil Co., FTC Dkt. No. 6934 (Interlocutory Order Sept. 15, 1958); Ernest Mark High, 56 F.T.C. 625, 632-3 (1959).

184 FTC Rules $\$$ 3.8, 3.10-.11, 28 Fed. Reg. 7087-88 (1963). The earlier prehearing conference rule, $\$ 3.10,20$ Fed. Reg. 3063 (1955), which paraphrased the corresponding court rule, FED. R. CIv. P. 16, was used almost solely for consent order negotiations. See Dixon, Practice and Procedure Before the Federal Trade Commission, 9 N.Y.L.F. 31, 56 (1963). 
ment of respondent's case or rebuttal of complaint counsel's allegations. ${ }^{185}$

Defining the positive limits of what was "necessary," however, proved more troublesome. One commentator went so far as to suggest that the necessity exception empowered the examiner to routinely order the deposition of FTC staff members. ${ }^{186}$ Respondents variously asserted that the requisite necessity was demonstrated by showing that the information either was in complaint counsel's possession or was relevant to respondent's case and not privileged. ${ }^{187}$

Despite several Commission decisions, the outlines of the necessity exception, as distinct from good cause, never became clear. Two staff members suggested in a bar journal article that if the requested documents were to be introduced in evidence, they were not confidential merely because they were located in the FTC's files; the production of documents that were to be placed in evidence could be compelled by satisfaction of discovery rules. ${ }^{188}$ But this only repeated in another context the effect of the express prehearing conference rule already noted in Balfour. Then, in Viviano Macaroni Co., ${ }^{189}$ the Commission appeared to hold that complaint counsel's proposed exhibits did come within the necessity exception. Though seemingly inconsistent with its earlier Macy decision, only the label and rationale of Viviano conflicted with earlier rulings; the result under either view was that the examiner had authority to order the release of FTG documents which would be introduced into evidence by complaint counsel. The Commission also stated in Viviano that vital documents such as verbatim copies of pretrial statements by government witnesses came within the

185 That the "necessary" exception was distinct from the "good cause" test of the confidentiality rule seemed apparent, especially in light of Balfour, where the Commission generally defined "good cause" as requiring respondent to

satisfy the Commission not only that the material sought is relevant and useful for defensive purposes, but also that its release would not impair any overriding public interest in preserving its confidentiality .... [taking] into account such considerations as basic fairness to the parties and the need for avoiding delay.

L.G. Balfour Co., 62 F.T.C. 1541, 1546 (1963).

188 Note, Discovery in Federal Administrative Proceedings, 16 STAN. L. REv. 1035, 1049-50 (1964).

187 Royal Constr. Co., FTC Dkt. No. 8690 [1965-1967 Transfer Binder] Trade REg. REP. I 17,722 (1966); Crown Cork \& Seal Co., FTC Dkt. No. 8687 (Interlocutory Order Feb. 8, 1967).

188 Mezines \& Parker, Discovery Before the Federal Trade Commission, 18 Ap. L. REv. 55, 71 (Winter-Spring, 1966); cf. Furr's, Inc., FTC Dkt. No. 8581 (Interlocutory Order Nov. 18, 1963); Texas Indus., Inc, FTC Dkt. No. 8656 [1965-1967 Transfer Binder] TradE REG. REP. I 17,253 (1965). Protection in this instance depends on whether the sensitivity of the documents, not their location, warrants in camera treatment during the hearing and a protective order governing the limits of disclosure to respondent. Furr's, Inc., supra.

180 FTC Dkt. No. 8666 [1965-1967 Transfer Binder] TRADE REg. REP. I 17,467 (1966). 
necessity exception. ${ }^{190}$ Once again earlier decisions had indicated that such information could be released by the examiner. On the other hand, Viviano and other cases held that necessity was not established by "an assertion showing only a possible general helpfulness to a respondent in preparation of its defense."191 Nor would necessity be found if the information was available from another source and respondent had not availed itself of compulsory process to obtain it. ${ }^{192}$ Thus, the necessity exception proved to be of little use in obtaining access to files available under the "good cause" rule. Finally, in Crown Cork of Seal Co., ${ }^{193}$ the Commission failed to distinguish between the necessity exception and the good cause requirement in ruling that exculpatory material in complaint counsel's possession (and not otherwise available) which would weaken or rebut the prosecution's case had to be disclosed.

At this point the boundaries of the exception appeared to have joined the rule: "necessity" and "good cause" were virtually identical. Moreover, the necessity exception had accomplished little since virtually all confidentiality questions were still being decided by the Commission rather than the examiners. Perhaps recognizing this unfortunate state of affairs, the Commission has relinquished its role of issuing redundant opinions on the release of confidential FTC files. Since May 25, 1968, the FTC has granted its examiners authority to rule on all questions of confidentiality at the pretrial stage. ${ }^{194}$ It no longer matters

190 The exception in pertinent part relates to material and information which may be necessary for use in connection with an adjudicative proceeding and this, in general, includes that which complaint counsel must use in the presentation of his case and other vital documents such as Jencks type statements.

Id. at 22,751; accord, R.H. Macy \& Co., FTC Dkt. No. 8650 [1965-1967 Transfer Binder] Trade REg. REP. I 17,458, at 22,693 n.* (1966); Inter-State Builders, Inc., FTC Dkt. No. 8624 [1965-1967 Transfer Binder] Trade REg. Rep. I 17,532, at 22,803 (1966). But see id. at 22,822 n.22 (Elman dissenting).

191 Viviano Macaroni Co., FTC Dkt. No. 8666 [1965-1967 Transfer Binder] Trade REg. REP. I 17,467, at 22,751 (1966); see e.g., Crown Cork \& Seal Co., FTC Dkt. No. 8687, at 5 (Interlocutory Order, Feb. 8, 1967) (slip opinion):

A mere averment of need is not enough nor is it sufficient that respondent is demonstrably in a position where he must of necessity defend himself against charges contained in the complaint. This latter is true of every respondent and hardly justifies a demand for virtually unrestricted access to the Commission's confidential files.

192 E.g., Seeburg Corp., FTC Dkt. No. 8682, at 5-6 (Interlocutory Order Oct. 25, 1966) (slip opinion); id. [1965-1967 Transfer Binder] TRADE REg. REP. I 17,843 (1967); Crown Cork \& Seal Co., FTC Dkt. No. 8687, at 6 (Interlocutory Order Feb. 8, 1967) (slip opinion).

193 Crown Cork \& Seal Co., FTC Dkt. No. 8687 (Interlocutory Order Feb. 8, 1967). See also Viviano Macaroni Co., FTC Dkt. No. 8666 [1965-1967 Transfer Binder] TRADE REg. REP. I 17,467, at 22,751 (1966); Graber Mfg. Co., FTC Dkt. No. 8038 [1965-1967 Transfer Binder] TRADE REg. REP. I 17,409, at 22,614 (1965) (ruling on a confidentiality application under the "good cause" test): "At the present time we agree there has been no showing of necessity for the respondents to have such extensive access . ..."

194 FTC Rules $\$ 3.36$. This rule change also authorized hearing examiners to issue 
whether the information is in the Commission's, the respondent's, or a third person's files. The new rule may be having a salutary effect. In the brief period since its adoption, the Commission apparently has not been called upon to determine whether good cause exists for release of FTC files-nor have FTC files been indiscriminately raided by rulings of examiners in the meantime. In other words, respondent's requests for materials in FTC files now are treated like all other discovery requests and are subject to the examiner's discretion, which will be reviewed by the Commission if abused.

\section{Disclosure of FTC Files to Respondent}

Of course, empowering the examiner to decide all confidentiality issues did not provide answers to the questions of greatest concern to the parties: What information in FTC files is confidential? Will it be released? Does it require protective treatment? The past confusion and lack of direction in FTC confidentiality policies is nowhere illustrated more sharply than in its ruling on requests for information from FTC files. Nominally, the current test is identical to the pre-1963 discovery standard-has "good cause" been shown for the release of the information? But the standard has a different meaning in the FTC file disclosure context. In discovery the focus was on whether the information was relevant to the preparation of respondent's defense. ${ }^{195} \mathrm{But}$, as the Commission set forth in Balfour, ${ }^{196}$ if a confidential file is involved attention is focused on the additional factor of the "public interest in preserving its confidentiality."

The quandary in which the Commission's application of this test has placed the hearing examiner is illustrated by the examiner's comments last year in Seeburg Corp.: ${ }^{107}$

subpoenas commanding the appearance of Commission officials or employees. Previously, the examiner's authority to subpoena Commission personnel was limited to requests for nonconfidential (and nonprivileged) information from them. See R.H. Macy \& Co., FTG Dkt. No. 8650 [1965-1967 Transfer Binder] TrADE Reg. ReP. $\int 1$ 17,344, at 22,503 (1965), appeal dismissed for lack of juris., R.H. Macy \& Co. v. Tinley, 249 F. Supp. 778 (D.D.C. 1966).

195 E.g., Topps Chewing Gum, Inc., FTC Dkt. No. 8463 [1963-1965 Transfer Binder] TRADE REG. REP. I 16,471 (1963).

196 See note 185 supra. It should also be noted that there is a third definition of "good cause" applied by the FTC in determining whether testimony or exhibits in adjudicative proceedings warrant in camera treatment. In that context the term requires a showing of clearly defined and serious injury. See Gellhorn 416-23.

${ }_{197}$ FTC Dkt. No. 8682, Transcript at 2048-9, quoted in Respondent's Request for Plenary Consideration by the Commission of Certification by the Hearing Examiner Concerning Commission Policies as to Confidential Files, at 3, filed Feb. 2, 1967. But complaint counsel altered his opposition to disclosing most of the disputed documents and the FTC did not accept the examiner's suggestion that it attempt to resolve this concern. Interlocutory Order (Mar. 27, 1967). 
Maybe it would be a good thing if the Commission looked into this question of what constitutes confidential matter and resolve[d] it and the basis for it. I would personally like to know myself, because everyone seems to have somewhat a different version about it . . . but let's find out what the answer to these things are and then maybe we'll all be thinking the same way.

Nor have examiners (or the Commission) been aided by respondents or complaint counsel. Each has taken hard and fast stands for or against disclosure without suggesting appropriate criteria for determining whether the documents warrant confidential treatment or require nondisclosure. Typical is the argument of complaint counsel in Crown Cork o Seal Co.: ${ }^{198}$

But in the case of this respondent, as has been the case in the past, and as will probably be the case in the future, whatever complaint counsel have done for respondent as a class, can never be enough. ... .

Additionally, respondent seeks, not specifically particularized documents for its defense, but general categories of documents which may, or may not, be used in defense. Such documents will, most assuredly, draw into this proceeding third party documents consisting of confidential and privileged communications from individuals and companies which desire to cooperate with the Commission as a respected Governmental agency, but which do not desire to submit information to the Commission when the Commission presumes to operate, . . . as an agent for respondent, an alleged law violator.

Doctrinal uncertainty makes it worthwhile to look at the current rules and various decisions governing the disclosure of Commission files on a functional basis: What type of information was sought? What factors did the Commission rely upon to release, protect, or refuse to divulge the data? Are any of the standards common to all types of information? Do these decisions withstand critical analysis? Can more rational criteria or alternative measures be suggested? ${ }^{199}$

198 FTC Dkt. No. 8687, Memorandum Brief of Complaint Counsel in Opposition to Certain Certified Recommendations of the Hearing Examiner Regarding the Permissive Scope of Respondent's Discovery, at 6, filed Nov. 9, 1966; cf. Seeburg Corp., FTC Dkt. No. 8682, at 4-5 (Interlocutory Order Oct. 25, 1966) (slip opinion) (ruling on motion for production of confidential documents).

199 This account is necessarily selective. In addition to space and time limitations, it is impossible to locate many FTC confidentiality decisions. Procedural decisions of hearing examiners are almost never reported; those by the Commission are seldom published except 
Before looking at the cases, it should be noted that the FTC treats as a question of pretrial discovery any attempt to obtain from its files the testimony of government witnesses, although traditionally (for example, in judicial trials) such inquiries are viewed as being within the rubric of the testimonial duty. ${ }^{200}$ By contrast, disclosure of pretrial statements of prosecution witnesses is governed by the "Jencks" rule. These matters have been examined elsewhere ${ }^{201}$ and will not be discussed further here.

FTG Rules. The current standard for release of FTG files by a hearing examiner is contained in three Commission rules-sections 3.34 (subpoenas), 3.36 (application to examiner for confidential Commission records), and 4.11 (general policy on release of confidential records). Read together, they require respondent to show that (a) the material sought is relevant and not privileged, (b) the scope of the application is reasonable, (c) the information is not available elsewhere, and (d) the information is required by law to be made available or (e) its disclosure is necessary in the interest of justice. Prior decisions have filled in some of the details.

Information Acquired by the FTC from Private Sources. In releasing information collected from private sources, the Commission's primary concern is to preserve the integrity of its investigative procedures by protecting documents entrusted to it while assuring that respondent has available all information it needs to defend itself and to avoid surprise. To show good cause in this circumstance, respondent must specify the documents and demonstrate a need for them. ${ }^{202}$

for internal staff consumption or to a select group. Nor is there a usable public index of current confidentiality decisions available. That these practices violate the intent if not the letter of $\S 3$ of the APA seems obvious. 5 U.S.C. $\$ 522(a)(2)(A)$ (Supp. III, 1968). See generally Davis, The Information Act: A Preliminary Analysis, 34 U. CHI. L. REv. 761 (1967). On the other hand, the Commission's lawlessness in failing to abide by these statutory instructions does not appear to be subject to the judicial enforcement provisions of the Act. Rather, the Commission cannot rely on prior unindexed decisions against a respondent unaware of them-unless a court were to read the statutory enforcement provisions as not precluding other judicial methods. See id. 783 n.56. Whether this statutory limitation, imposed on the FTC as a result of its non-indexing of procedural decisions, will ever have any significance seems doubtful. But the lack of an index has meant that FTC decisions often fail to account for prior decisions. See, e.g., Gellhorn 429 n.153. Nor is it uncommon for the Commission staff to be unaware of prior Commission rulings-at least this author has been called upon by staff attorneys to advise them of earlier FTC decisions on procedural subjects.

200 See Gellhorn 423-7.

201 For a review of the FTC's application of the government-secrets privilege at the hearing and of its rulings on prior statements of prosecution witnesses at the adjudicative stage, see Gellhorn 423-33.

202 E.g., Associated Merchandising Corp., FTC Dkt. No. 8651, 3 TRADE REg. REP. I 18,128 (1967); Crown Cork \& Seal Co., FTC Dkt. No. 8687, at 4 (Interlocutory Order 
Relevance is established by describing the documents with as much particularity as the situation permits and by showing why and how they will aid respondent in meeting the charges. ${ }^{203}$ The Commission has repeatedly rejected statements by respondent that it "need[s] [the] documents generally"204 and has noted that attempts to rummage through FTC files "merely for 'fishing' purposes to determine whether material might be extracted therefrom which could be exploited by the defense will not be allowed." ${ }^{205}$ But the sufficiency of the description is not determined by an arbitrary formula. It is dependent on respondent's knowledge, the nature of the charges, and, most important, respondent's demonstration of need.

Two cases illustrate these points. In Balfour, ${ }^{206}$ a case involving a monopoly charge under section 5 of the FTC Act, respondents sought documents obtained by the Commission from respondents, third party documents obtained by the Commission from respondents' files, and correspondence between respondents and the FTC. These documents had been supplied by respondents over a period of more than thirty years throughout a series of generally related FTG investigations of their business activities. More than 700 of these documents had been introduced during the interval hearings; ${ }^{207}$ at least another 900 were in FTG files. ${ }^{208}$ Respondents had searched their files and determined that copies had not been retained. They also asserted that some of the missing documents contained exculpatory material, but they could not provide specific details to support this claim. There was no dispute that these documents related to the issues of the case; the complaint was "necessarily broad, covering a long period of respondents' business life," and "the charge ... [was] capable of proof and defense by an

Feb. 8, 1967) (slip opinion); Viviano Macaroni Co., FTC Dkt. No. 8666 [1965-1967 Transfer Binder] TRAdE Reg. ReP. I 17,467 (1966); Sperry \& Hutchinson Co., FTC Dkt. No. 8671 [1965-1967 Transfer Binder] Trade REg. REP. If 17,505 (1966); L.G. Balfour Co., 61 F.T.C. 1491, 1492 (1962), 62 F.T.C. 1541, 1546 (1963).

203 E.g., Associated Merchandising Corp., FTC Dkt. No. 8651, 3 Trade Reg. Rep. If 18,128 (1967); L.G. Balfour Co., 61 F.T.C. 1491, 1492 (1962):

In analyzing the relevance of the papers involved, the examiner should be governed by the charges made in the complaint. It is respondent's burden to show why, and how, the requested documents will aid in meeting these charges.

204 E.g., Crown Cork \& Seal Co., FTC Dkt. No. 8687, at 6 (Interlocutory Order Feb. 8, 1967) (slip opinion).

205 E.g., L.G. Balfour Co., 62 F.T.C. 1541, 1546 (1963).

206 Id.

207 Id. at 1547 n.17.

208 Id. [1963-1965 Transfer Binder] TRADE REg. REP. If 16,635 (1963). In this sequel to the Commission's order that complaint counsel produce copies of respondent's documents, the FTC held that complaint counsel had complied even though some of the 900 documents produced contained notations indicating that other documents existed; however, they could not be found after a diligent search of FTC files. 
almost infinite variety of evidence."209 In such circumstances, greater specificity was not required.

Another indication of the flexibility of the relevancy requirement is the Commission's decision last year in Crown. ${ }^{210}$ In this section 7 proceeding under the Clayton Act, respondent requested documents relating to its proposed "failing company" defense. It hoped the documents would show that the acquired company was failing because of inept management, obsolete machinery, dissension among the board of directors, disloyalty of corporate officers, and an unsound financial condition. Again respondent did not specify the documents with precision because it did not know their identity. However, it did list 55 persons and corporations who might have submitted information to the FTC, and the Commission allowed the request for all documents from these third parties relating to the specific failing company allegations asserted by respondent. . $^{211}$

These cases also demonstrate that the reasonableness of the scope of respondent's application - the second requirement of the current rules -is not determined by the number of the documents sought. Reasonableness, rather, is a balance of several factors. On the one hand, how critical is it that respondent obtain these documents? Are they central to the preparation or presentation of his case, or is it only possible that some helpful information will be revealed? ${ }^{212}$ If respondent can develop similar defensive material in other ways, the examiner can be expected to reject the request. ${ }^{213} \mathrm{On}$ the other hand, the number of documents may have a significant impact on whether the application will be granted since discovery which will unduly delay the proceed-

20962 F.T.C. 1541,1547 (1963).

210 FTC Dkt. No. 8687 (Interlocutory Order Feb. 8, 1967) (unreported opinion).

211 The FTC order, however, was conditioned on respondent's showing that the information was not directly available from the 55 companies listed in its request.

On the other hand, where specificity is possible, the Commission has applied the relevancy requirement strictly. E.g., Associated Merchandising Corp., FTC Dkt. No. 8651, 3 Trade Rec. REP. II 18,128 (1967).

212 In Crown, for example, the Commission chided respondent for saying in effect that it may have bought a failing company without knowing that it was failing. "This plea has little to recommend it except candor but we think its candor saves it. If respondent's suspicions are correct and the company was in fact failing, it is important that that fact be brought to light ... because it bears vitally upon the central issue ..." of the case. Crown Cork \& Seal Co., FTC Dkt. No. 8687, at 5 (Interlocutory Order Feb. 8, 1967) (slip opinion) (emphasis added). The Commission also was influenced by complaint counsel's implied concession that some of the documentation would be useful to respondent when complaint counsel admitted that he planned to use some of this documentation on cross-examination to "keep them [respondent] honest," a surprise tactic which the FTC found objectionable and inconsistent with current discovery practice.

213 E.g., Crown Cork \& Seal Co., FTC Dkt. 8687, at 6 (Interlocutory Opinion Feb. 8, 1967) (slip opinion). 
ings is disapproved by the Commission. ${ }^{214}$ The Commission is aware of the propensity of antitrust defendants to rely on discovery devices to delay proceedings.

These standards of relevance and reasonableness are unexceptionable. Although one might quarrel with the rigidity of certain applications, they generally carry forward into the confidentiality context the interpretation of similar discovery rules in Commission and judicial practice. ${ }^{215}$ The same cannot be said for the requirement that respondent show that the requested documents are not available to it elsewhere. Unless similar information is already in evidence, ${ }^{216}$ or the documents sought constitute the underlying data supporting a complaint counsel exhibit, ${ }^{217}$ the Commission has obstinately refused disclosure until respondent demonstrates that it is unable to obtain the information from other sources by voluntary or compulsory methods. ${ }^{218}$ It is here that the Commission's oft-criticized double standard on confidentiality comes into sharper focus. The Commission's analysis reflects this difficulty.

In protecting its files from respondent's claims, the FTC often argues that confidentiality must be maintained so as not to imperil business

214 E.g., L.G. Balfour Co., 62 F.T.C. 1541, 1546 n.15 (1963) (citing authorities); see Associated Merchandising Corp., FTC Dkt. No. 8651, 3 TRADE REg. REP. ๆ 18,128 (1967); cf. United States v. Assoc. Merchandising Corp., 261 F. Supp. 553 (S.D.N.X. 1966). A recent discovery case applying the same standard, Associated Merchandising Corp., FTC Dkt. No. 8651, 3 TRADE REC. REP. I 18,102, at 20,547 (1967), upheld an examiner's refusal to issue subpoenas duces tecum and deposition discovery of 223 persons at respondents' request; it would have required pretrial discovery depositions in 12 different cities and the issuance of about 250 subpoenas. According to the Commission, respondents failed to demonstrate that the examiner abused his discretion since they had not shown "that they could not adequately defend themselves without the depositions requested . . . [or] that there are no alternatives to the sweeping discovery demands made."

215 See note 177 supra and accompanying text; L.G. Balfour Co., 62 F.T.C. 1541, 1546 nn.14 \& 16 (1963).

216 In Seeburg Corp., FTC Dkt. No. 8682, at 2 (Interlocutory Order Mar. 27, 1967), the examiner recommended disclosure of a third person's document because "there is no longer anything secret or confidential about it 'since public record evidence has already been received without objection relating to such acceptances.' " The Commission reluctantly ordered disclosure. See also id. [1965-1967 Transfer Binder] TRADE REG. REP. I 17,843 (1967).

217 Grand Union Co., 62 F.T.C. 1491 (1963); Columbia Broadcasting System Inc., 62 F.T.C. 1518 (1963).

218 E.g., compàre Sperry \& Hutchinson Co.; FTC Dkt. No. 8671 (Interlocutory Order Sept. 28, 1966), with Associated Merchandising Corp., FTC Dkt. No. 8651, 3 TradE REc. REP. I 18,128 (1967). However, if the third party prefers that the Commission divulge the information, the FTC files will be released to respondent. E.g., Seeburg Corp., FTG Dkt. No. 8682, at 5 (Interlocutory Order Oct. 25, 1966) (not to be confused with an FTC interlocutory order upholding consent order procedure issued in this case on the same date, id. [1965-1967 Transfer Binder] TRADE REg. REP. If 17,729); Libby-Owens-Ford Glass Co., 56 F.T.C. 1661 (1960). 
confidence in the integrity of its files. ${ }^{219}$ According to the FTC, respondents must first attempt compulsory discovery, often against many persons, for material already collected by the Commission and compiled in one place (often with the aid of legal compulsion). Aside from the inefficiency and burdensomeness of this approach, the Commission's ready reliance on compulsory process in conducting its investigations belies the soundness of its a priori argument that zealous FTC confidentiality policies are the touchstone of business cooperation. The foundation of business cooperation in practice is the ever present and viable threat of compulsion. ${ }^{220}$ Moreover, as Commissioner Elman correctly points out, as a result of the compulsory discovery requirement, respondent is not on a parity with complaint counsel with respect to available discovery since complaint counsel can demand documents of respondent even though they are available elsewhere.221 Commissioner Elman has also noted that the requirement introduces

219 Sensitive information ... [relating to marketing strategies, technical, marketing and purchasing experiences, and plans of customers and competitors] should not be released by the Commission from its confidential files without compelling need. Disclosing information from the Commission's files under a lesser standard would necessarily engender resistance on the part of companies and individuals cooperating in Commission industry investigations. It would be likely to seriously retard voluntary compliance with the Commission's efforts to obtain the data which it needs in industry inquiries. Obviously, the cooperation which the Commission has received in the past from business depends in large part on the confidence of industry that confidential data submitted to this Agency will not be released in an adjudicative proceeding unless specific and concrete need therefor has been shown.

... At this time no determination can be made that such data is unavailable to respondent under these [discovery] procedures. Wherever sensitive data relating to customers or competitors .... is concerned, respondent should utilize the procedures made available by the Commission's Rules to secure the data directly from the source rather than from the Commission's confidential files. Under these procedures, the third parties from whom information is sought are, of course, entitled to state their views on the competitive implications of disclosing the information requested and on the proper measures for preserving the confidentiality of the data produced pursuant to subpoena where such measures are appropriate. ... Certainly due process requires no more than that respondent be able to secure evidence to present its defense. Respondent, of course, does not have an unqualified right to demand confidential data from the Commission's files at any particular time or stage in a proceeding.

Seeburg Corp., FTC Dkt. No. 8682, at 5-6 (Interlocutory Order Oct. 25, 1966) (slip opinion). 220 Compare Withrow, Investigations by the Federal Trade Commission-As Seen by the Potential Respondent, 29 ABA ANTrmust SEcrion 81 (1965), with Williams, Investigations by the Federal Trade Commission, 29 ABA ANTITRusr SEction 71 (1965). The FTC's business cooperation argument is also refuted by the Commission's rejection of a similar argument by respondents. In denying discovery of third party documents to a respondent who alleged that the third parties were hostile to respondent's desire to obtain the information, the Commission said: "We are not aware that friendliness and a spirit of cooperation is a necessary precondition to the effectiveness of compulsory process." Crown Cork \& Seal Co., FTC Dkt. No. 8687, at 6-7 (Interlocutory Order Feb. 8, 1967) (slip opinion); cf. Associated Merchandising Corp., FTG Dkt. No. 8651, 3 TRADE REG. REP. I 18,128 (1967).

221 Crown Cork \& Seal Co., FTC Dkt. No. 8687, at 6 (Interlocutory Order Feb. 8, 1967) (slip opinion) (dissenting opinion); FTC Rules §§ 3.33-.34; see All-State Indus., Inc., FTC Dkt. No. 8738, 3 TRADE REg. REP. I 18,103 (1967). 
a double standard into the enforcement of laws administered by both the FTG and the Justice Department. ${ }^{222}$ If a merger case were brought by the Justice Department instead of the FTC, the government would have to produce unprivileged documents at the defendant's request even if they were available-voluntarily or compulsorily-from third persons. ${ }^{223}$ "Surely the rights of a party charged with violating the merger law should not be substantially diminished because the proceeding is brought by the Federal Trade Commission rather than the Department of Justice."224 Finally, this policy is contrary to the Commission's rationale that a primary consideration in determining whether documents should be released is avoidance of undue delay or unnecessary burdens on either party or on third persons. ${ }^{225}$

The unfairness of the unavailability requirement was eloquently summarized by Elman in Crown:226

Why should such a requirement be imposed on a respondent? It will take months for respondent to go through the laborious process of subpoenaing third parties in an effort to secure copies of the documents in the possession of complaint counsel. And when the process is completed, how will respondent's counsel know that they have gotten everything that complaint counsel now have? Will there indeed be that "mutual knowledge of all the relevant facts gathered by both parties" which the Supreme Court in Hickman v. Taylor said "is essential to proper litigation"? And even if the answer could be yes, what discernible public interest is served by stretching out the prehearing process for this purpose? The advantage of discovery is that it avoids all the burdens and delays involved in obtaining from third persons documents which are readily available and possessed by the other party. It seems to me that the Commission fails to respect the spirit and letter of its own Rules of Practice by denying discovery here.

222 See Crown Cork \& Seal Co., FTC Dkt. No. 8687 (Interlocutory Order Feb. 8, 1967) (slip opinion) (Elman dissenting).

223 As a litigant-especially as the complaining party-the government is subject to discovery like any other party. United States v. Proctor \& Gamble Co., 356 U.S. 677, 681-82, (1958). Thus, only privileged documents are exempt from discovery. Documents which are labeled confidential solely because of their location in a government agency's files are not privileged and, therefore, are not protected from disclosure during discovery. United States v. Reynolds, 345 U.S. 1, 6 (1953); Communist Party of the United States v. SACB, 254 F.2d 314, 321 (D.C. Cir. 1958). On the other hand, the question of privilege does become critical in FTC discovery when respondent seeks FTC developed information. See text accompanying notes 248-81 infra.

224 Crown Cork \& Seal Co., FTC Dkt. No. 8687, at 6 (Interlocutory Order Feb. 8, 1967) (slip opinion) (dissenting opinion).

225 See note 214 supra and accompanying text.

226 Crown Cork \& Seal Co., supra note 224, at 5 (dissenting opinion). 
Even if its factual basis is sound, the Commission's business cooperation argument is not a persuasive response. ${ }^{227}$ Notice by the Commission (or respondent) to third parties that respondent is requesting their documents from FTC files would provide them with an adequate opportunity to object or to seek a protective order without subjecting such third parties to the inconvenience of being directly involved in the discovery process.

However, in applying the final requirement-that respondent show that disclosure is necessary in the interest of justice ${ }^{228}$ - the Commission generally has exhibited the flexibility and imagination which justifies continuing faith in the administrative process. The all-or-nothing approach of the unavailability test is abandoned. Instead, the Commission has sought to strike a reasonable balance between assuring that information provided by third parties is not needlessly disclosed and making needed information available to respondent for preparing and presenting its case. In doing so, the FTC has carefully examined respondent's need for the data, weighed complaint counsel's comparative advantage in having such information available, appraised the sensitivity of the

227 Nor is the Commission's due process analysis (quoted at note 219 supra) apt. It may be true, as the FTC in effect argued, that due process does not require more than the clumsiest FTC procedure which allows respondent to secure defensive evidence [see Sperry \& Hutchinson Co. v. FTC, 256 F. Supp. 136, 142-3 (S.D.N.Y. 1966)], but this hardly justifies cumbersome, time consuming practices when equally serviceable and more efficient alternatives are available. See note 6 supra and accompanying text.

228 The scope of the alternative requirement-that "information to which the applicant is entitled by law" will be disclosed (FTC Rules $\S 3.36(a)$ )-loosely follows the fifth and seventh exemptions to amended $\S 3$ of the APA limiting required disclosure of internal agency communications and investigatory files to matters routinely available to litigants. 5 U.S.C. $\$ 552(b)(5) \&(7)$ (Supp. III, 1968). Although these exemptions from the Information Act are not identical and raise several questions (compare Attorney General's Memorandum on the Public Information Section of the Administrative Procedure Act 35-38 (1967), with Davis, The Information Act: A Preliminary Analysis, 34 U. CHr. L. REv. 761, 794-7, 799-800 (1967)), this FTC Rule provision (\$ 3.36(a)) apparently is limited to prehearing conference disclosures, (e.g., names of complaint counsel's witnesses and copies of his intended exhibits) and Jencks-type statements. See notes 171, 172, \& 183 supra. See also Sperry \& Hutchinson Co v. FTC, 256 F. Supp. 136, 143.4 (S.D.N.Y. 1966). And the latter need be disclosed only after the government witness has testified during the hearing. E.g., Viviano Macaroni Co., FTC Dkt. No. 8777 [1965-1967 Transfer Binder] TRADE REg. REP. I 17,467, at 22,752 (1966). But see Sperry \& Hutchinson Co., FTC Dkt. No. 8671 (InterIocutory Orders Sept. 28, \& Oct. 4, 1966). Because of these and other exemptions, amended $\S 3$ of the APA probably will have little impact on disclosure of FTC files to respondent. See Seeburg Corp., FTC Dkt. No. 8682 [1965-1967 Transfer Binder] TRAdE REg. REP. I 17,729, at 23,055-6 (1966) (Interlocutory order upholding consent negotiation procedure):

The [Information] Act does not enlarge the discovery rights of a private party engaged in litigation with the Commission to secure documents . . . which have hitherto never been considered as subject to discovery in this Agency's proceedings.

Id. at 7-11 (Interlocutory Order Oct. 25, 1966) (unreported opinion denying production of documents); cf. Lamar Life Ins. Co., 21 Ad. L.2d 254 (FCC 1967). 
data, and experimented with protective measures by limiting disclosure to respondent's counsel or independent experts.

In its 1963 Balfour decision the Commission set forth the basic standard for measuring respondent's need. Respondent must show that the material would be "useful for defensive purposes" and that disclosure is consistent with "basic fairness to the parties and the need for avoiding delay" while not impairing "any overriding public interest in preserving its confidentiality."229 In Seeburg ${ }^{230}$ respondent urged its compliance with this standard by asserting that its discovery of FTC files was designed to test the accuracy of staff counsel's statistical proof and to elicit evidence in support of respondent's theory of the case. The Commission relied on the examiner's careful analysis of the particular request and denied the application on the ground that respondent had shown only the "generalized relevance" and "possible helpfulness" of the material.

Both Crown ${ }^{231}$ and $S$ \& $H,{ }^{232}$ by contrast, illustrate the type of material which, if properly identified and not available elsewhere, will be released. In Crown, the FTG indicated that it would release information in its files which might establish a failing company defense to a merger law violation. In $S$ \& $H$, the Commission ordered production of complaint counsel's correspondence with retailers who were not called as witnesses against the trading stamp firm. $\mathrm{S} \& \mathrm{H}$ had asked to inspect these documents on the grounds that "they tend to refute . . .

229 L.G. Balfour Co., 62 F.T.G. 1541, 1546 (1963).

230 FTC Dkt. No. 8682, at 1 (Interlocutory Order Oct. 25, 1966) (slip opinion): "It should be noted at the outset that respondent has apparently had full disclosure of complaint counsel's case, both with respect to the witnesses to be utilized, the documents to be introduced, the underlying data supporting such exhibits, and the theory of the case." See also Sperry \& Hutchinson Co., FTC Dkt. No. 8671 [1965-1967 Transfer Binder] TraDE REG. REP. If 17,505, at 22,780 (1966):

[R]espondent's chief purpose is not to seek specific documents or documents respecting a specific defensé which upon analysis might demonstrate good cause. Rather, as the phrasing of its request indicates, it is asking for general access to the Commission's confidential investigational files merely to see whether something useful to its defense may turn up. This is clearly an insufficient ground for the production of such records. Respondent has made no showing of any kind which would constitute good cause for the requested access.

Nor is it "controlling that [the] applicant is of the view that access to Commission investigation files may assist [the] applicant in preparing its defense to the charges of the complaint." Libbey-Owens-Ford Glass Co., FTC Dkt. No. 7643 [1959-1960 Transfer Binder] Trade REG. REP. If 28,615 (1960).

Cases decided since July 1, 1967, have yet not expanded the concept of "defensive use" of FTC file material to include "pure discovery," but a consistent application of the discovery rules might require such an expansion if the other criteria of the confidentiality rules were satisfied. At least there is no theoretical barrier to such an extension.

231 Crown Cork \& Seal Co., FTC Dkt. No. 8687 (Interlocutory Order Feb. 8, 1967).

232 Sperry \& Hutchinson Co., FTC Dkt. No. 8671 (Interlocutory Order Sept. 28, 1966). 
any inferrence [sic] drawn from unsupported documentary evidence that respondent has unfairly restrained its licensees" from issuing extra trading stamps-the essence of the Commission's charge..$^{233}$

The Commission's policy regarding the release of information obtained by it through special reports under section 6(b) of the FTG Act further illustrates the Commission's emphasis on respondent's establishing its need for the documents to prove its case and to prevent surprise as critical factors. In Mississippi River Fuel Corp. ${ }^{234}$ and Texas Industries, Inc. ${ }^{235}$ special reports obtained by the Commission as part of an industry-wide informative investigation-and not for regulatory purposes-were protected from disclosure because they had not been made available to complaint counsel, who therefore had no unfair advantage, and because the substantial cooperation the FTC was receiving during this continuing investigation reflected the reporting companies' "expectation and understanding that these Reports would not be released" for use in adjudicative proceedings. ${ }^{236}$ But to the extent that respondent's application in Mississippi River Fuel involved documents identified by complaint counsel which were likely to be placed in evidence in another complaint proceeding, the FTC directed the examiner to reconsider the motion and recommend disclosure if their relevance to respondent's case outweighed any need for secrecy. Consistent with these rulings, the Commission ordered release of section 6(b) reports in Grand Union Co. ${ }^{237}$ and Columbia Broadcasting

233 BNA Antrtrust \& Trade Reg. ReP. No. 274, A-3 (Oct. 11, 1966). The order, which was issued during trial rather than pretrial, was justified as preventing further prolongation of the hearings since respondent's alternative was to subpoena persons from as far away as Denver and Salt Lake City. Sperry \& Hutchinson Co., FTC Dkt. No. 8671 (Interlocutory Order Oct. 4, 1966).

234 FTC Dkt. No. 8657 [1965-1967 Transfer Binder] TrAde REg. REP. If 17,321, at 22,480 (1965): "Although it is possible ... that some of the documents may be relevant or helpful to respondent in the preparation of its defense, this is insufficient to override the public interest against disclosure." But when it was revealed later that complaint counsel had access to some of the reports, the FTC remanded the matter to the examiner to determine whether disclosure was necessary. See BNA ANtrtrust \& Trade REg. REP. No. 295, B-4 (March 7, 1967).

235 FTG Dkt. No. 8656 [1965-1967 Transfer Binder] Trade Reg. Rep. I 17,253 (1965).

238 Id. at 22,352. Significantly, the Commission limited this ruling when it noted:

While we have determined that there is a very substantial public interest in not releasing the Special Reports in question to respondent in this case, we would do so if the needs of basic fairness so dictated. They do not. . . . [Since] no part of these Reports has been or will be turned over to complaint counsel to be introduced as evidence in this proceeding . ... denial of access ta them on the part of respondent is not a case of the Commission's denying a respondent 'access to evidence which it controlled.' [Citing Union Bag-Camp Paper Corp. v. FTC, 233 F. Supp. 660, 666 (S.D.N.Y. 1964)]. . . . All evidence in the possession of complaint counsel will be subject to full discovery, which, under the Commission's Rules of Practice, is available to respondent as well as to complaint counsel. Id. (emphasis added).

23762 F.T.C. 1491 (1963). Moreover, since the Commission required complaint counsel 
System, Inc., ${ }^{238}$ where complaint counsel planned to introduce them into evidence. The effect of this ruling was recently extended to include data collected by section $6(\mathrm{~b})$ reports which were available to complaint counsel even though he did not plan to introduce the information into evidence. ${ }^{239}$

Current FTC discovery rules suggest that "real or actual need" can now be established by a mere showing that the information is likely to be helpful to respondent's preparation of its case. But no reported case goes this far.

Grand Union and CBS also illustrate the Commission's use of protective measures to allow release of information from FTC files to a respondent while assuring confidential treatment of a third person's sensitive business data. Respondent's counsel was permitted to examine, summarize, or copy the reports of competitors, but this information was not to be disclosed to anyone other than such counsel except third parties (e.g., experts), approved by the trial examiner; the Commission specifically forbade disclosure to respondent. ${ }^{240}$ Noting that this protective procedure was not perfect, the Commission ruled in Furr's, Inc. ${ }^{241}$ that it was not applicable every time FTC files were released. Rather, the effect of these restrictions on respondent's "practical and expeditious preparation of its defense" was to be balanced against the sensitivity of the data, the likelihood of its ultimate disclosure on the public record at trial, and the need to prevent undue delay or confusion in the conduct of FTC proceedings. ${ }^{242}$

to produce approximately 180 reports even though he planned to introduce in evidence only a tabulation based on 20 of them, the mere availability of $\S 6(\mathrm{~b})$ reports to complaint counsel may now justify disclosure.

23862 F.T.C. 1518 (1963).

239 In Lehigh Portland Cement Co., FTC Dkt. No. 8680 (Intexlocutory Order), reported in BNA ANTITRUST \& TRADE REg. REp. No. 355, A-10 (Apr. 30, 1968), the FTC affirmed an examiner's order for disclosure of a list of all acquisitions by Portland Cement companies of ready-mixed concrete manufacturers for the years 1965-1968. Although part of the file of an industry-wide investigation, the information could hardly be classified as sensitive.

240 See notes 237 \& 238 supra. Apparently complaint counsel is to police these disclosures. Respondent's counsel was directed to provide Commission counsel with copies of everything copied or noted from these files. All such copies and summaries, as well as any additional notes made by respondent's counsel regarding these documents, were to be returned to the FTC's files on termination of the proceeding.

Two commissioners professed little faith in these protective measures and dissented because it was "manifestly unfair to subject the materials furnished by the various people not parties to this action to examination by their competitors. ..." One of the dissenters, Commissioner Macintyre, also asserted that this procedure went beyond the needs of due process and that the same ends could have been better achieved in other ways.

241 FTC Dkt. No. 8581 (Interlocutory Order Nov. 18, 1963).

242 On the other hand, the standard for determining whether protective measures should be applied at pretrial should not be as stringent as at trial. There is no "public interest" in disseminating discovery on the public record as there is in the case of trial 
Information Developed by the FTG. Not all information sought by respondents from the Commission's files is acquired from private sources. The release of file information developed by the FTC has been the subject of numerous applications. However, except for copies of statements by government witnesses which will be released to respondent during trial after they have testified, ${ }^{243}$ the Commission's general policy has been to deny the release of such information. The data is of two kinds: information in the Commission's litigation file developed for the complaint proceeding; and other nonlitigation documents. The Commission's treatment of requests for these two kinds of information is governed by different principles.

(a) Litigation documents. Probably the most sensitive of the litigation documents in FTC files are those identifying the person whose complaint initiated or aided the FTC's proceeding against respondent. Because of its heavy reliance on private complainants for information of law violations warranting prosecution, ${ }^{244}$ the Commission has zealously protected the identity of these informers from public or respondent disclosure. ${ }^{245}$ The informant may be a volunteer or may have been requested or compelled to provide information; his relationship to respondent may be that of victim, competitor, accomplice, or knowledgeable but disinterested bystander. Whatever the basis of his being an informer or of his relation to respondent, the Commission has asserted that confidentiality is necessary to encourage the continued flow of this information. ${ }^{246}$ Otherwise future complainants might be reluctant to come forward with information for fear of economic retaliation or of a decline in status in the business community.

evidence. Cf. 15 U.S.C. $\$ 1813$ (c) (1964) (Antitrust Civil Process Act). But cf. 15 U.S.C. § 30 (1964) (Publicity in Taking Evidence Act). Discovery should not be sidetracked into hearings on whether confidential treatment is warranted; counsel's professional statement seems sufficent. The information may never be introduced into evidence so the trial question may be irrelevant; and the objecting party's concern may not be with disclosure to respondent but rather to the public at large. See note 164 supra.

243 E.g., Inter-State Builders, Inc., FTC Dkt No. 8624 [1965-1967 Transfer Binder] TrAde REg. REP. I 17,532 (1966); L.G. Balfour Co., FTC Dkt. No. 8435 [1965-1967 Transfer Binder] TrADE REG. REP. If 17,532, at 22,799 (1966); Viviano Macaroni Co., FTC Dkt. No. 8666 [1965-1967 Transfer Binder] TRADE REG. REP. If 17,467, at 22,750-1 (1966). See generally Gellhorn 428-33.

244 See note 11 supra.

245 E.g., Graber Mfg. Co., FTC Dkt. No. 8038 [1965-1967 Transfer Binder] TRADE REG. REP. If 17,409, at 22,614 (1965); Texas Co., 60 F.T.C. 1887, dismissed for lack of juris., 301 F.2d 662 (5th Cir.), cert. denied, 371 U.S. 822 (1962); Columbus Coated Fabrics Corp., 54 F.T.C. 1885 (1957).

246 Graber Mfg. Co., FTC Dkt. No. 8038 [1965-1967 Transfer Binder] TrAdE REg. REP. If 17,409 (1965). While the rationale of confidentiality supports only the secret identity of volunteer informers, policy considerations of equal treatment for all informers suggests that the Commission's blanket protection is appropriate. 
On the other hand, the informer may have information important to the defense, and respondent may therefore have a legitimate, even urgent need to know his identity. In this situation both the APA ${ }^{247}$ and the due process clause would require disclosure if respondent cannot obtain such information by other means.

Judicial protection of the "informer's privilege" has recognized these competing interests and ruled that

$[w]$ here the disclosure of an informer's identity . . . is relevant and helpful to the defense of an accused, or is essential to a fair determination of a cause, the privilege must gave way. ${ }^{248}$

Similarly, the Commission's rules recognize that the usual standard of strict confidentiality will be waived "as required by law."249 Although there have been indications in some antitrust prosecutions by the Justice Department that the scope of this exception is expanding, ${ }^{250}$ no respondent appears as yet to have been successful in demonstrating good cause to the Commission for revelation of an informant's identity. ${ }^{251}$

2475 U.S.C. $\$ \S 555$ (d), 556(d) (Supp. III, 1968); see FTC Rules § 3.41(c). In fact, the loose language of amended $\$ 3$ of the APA would appear to require disclosure of an informer's identity; but the commentators agree that the language will not be so interpreted. Davis, The Information Act: A Preliminary Analysis, 34 U. CHI. L. Rev. 761, 793 n.84 (1967); Attorney General's Memorandum on the Public Information Section of the Administratiye Procedure Act 32-34 (1967); Stewart \& Ward, FTC Discovery Depositions, The Freedom of Information Act and Confidential Informants, 37 ANrrrrusr L.J. 248 (1968); see Tobacco Institute v. FTC, Civ. No. 3035-67 (D.D.C. filed Nov. 29, 1967), noted in BNA ANTITRUsT \& Trade Reg. Rep. No. 334, A-11 (Dec. 5, 1967); cf. Bristol-Myers Co. v. FTC, 5 Trade REG. REP. (1968 Trade Cas.) I 72,496 (D.D.C.).

248 Roviaro v. United States, 353 U.S. 53, 60-61 (1957); see McCray v. Illinois, 386 U.S. 300, 309-12 (1967); Churder v. United States, 387 F.2d 825 (8th Cir. 1968); United States v. Day, 384 F.2d 464 (3d Cir. 1967); Note, The Privilege of Withholding the Identity of an Informer, 28 U. PrrT. L. Rev. 477 (1967).

249 FTC Rules § $2.2(d)$.

250 United States v. National Steel Corp., (S.D. Tex. 1962), noted in BNA ANTITRUST \& TrAdE Rec. Rep. No. 49, A-1 (June 19, 1962).

The Supreme Court's leadership in this area has been in the criminal cases where the balance between the need to protect and to disclose may differ from administrative actions by the FTC. Presumably, the public interest in protecting the flow of information is just as strong in the agency proceeding, although confidentiality may not be as critical since self-interest is probably the motivation for most private complaints to the FTC. However, respondent's right to prepare his defense is not as strong in the FTC hearing. On the other hand, it is arguable that the government's position in an FTC prosecution should be no better than a plaintiff in a private antitrust action who will be required to disclose the sources of information on which his action is based. On balance, therefore, tests developed in criminal cases seem relevant to FTC proceedings.

251 As a practical matter, the disclosure of the complainant's identity is probably of marginal interest to respondent-despite the vigor of their arguments for disclosure in some of the cases. In the business context it usually is neither difficult to determine who 
A similar balancing of interests has been adopted by the Commission in ordering disclosure of reports, memoranda, and notes prepared by complaint counsel in the preparation of the government's case against respondent. Again, in Hickman v. Taylor, ${ }^{252}$ the standard has been set by the Supreme Court:

Were such materials open to opposing counsel on mere demand, much of what is now put down in writing would remain unwritten. ... Inefficiency, unfairness and sharp practices would inevitably develop..... And the interests of the clients and the cause of justice would be poorly served.

We do not mean to say that all written materials obtained or prepared by an adversary's counsel with an eye toward litigation are necessarily free from discovery in all cases. Where relevant and non-privileged facts remain hidden in an attorney's file and where production of those facts is essential to the preparation of one's case, discovery may properly be had. Such written statements and documents might, under certain circumstances, be admissible in evidence or give clues as to the existence or location of relevant facts. Or they might be useful for purposes of impeachment or corroboration. And production might be justified where the witnesses are no longer available or can be reached only with difficulty. . . . But the . . burden rests on one who would invade that [attorney] privacy to establish adequate reasons to justify production....

This "work product" standard governs Commission proceedings. ${ }^{253}$

has information needed to present a defense nor hard to guess the identity of the informer.

252329 U.S. 495, 511-12 (1947) (emphasis added).

253 E.g., Viviano Macaroni Co., FTC Dkt. No. 8666 [1965-1967 Transfer Binder] TradE REg REP. If 17,467, at 22,752 (1966); Graber Mfg. Co., FTC Dkt. No. 8038 [1965-1967 Transfer Binder] Trade REg. REP. If 17,409, at 22,614 (1965).

Problems emerging from the assertion either of privilege or of the right to "work product" should be examined in the light of principles established by the federal courts, especially in those cases in the antitrust field dealing with the validity of the claim of privilege or the application of the "work product" rule.

L.G. Balfour Co., 61 F.T.C. 1491, 1492-3 (1962). However, the Commission has indicated that the scope of the work product protection of the files of its attorneys is greater than that accorded in private civil litigation because complaint counsel are "government lawyers acting in the public interest." Id., 62 F.T.C. 1541, 1546 (1963). This rationale, however, also supports a contrary argument. See Inter-State Builders, Inc., FTC Dkt. No. 8624 [1965-1967 Transfer Binder] Trade REg. REP. ff 17,532, at 22,814-5 (1966) (Elman dissenting). In any case, the FTC has ruled that "[d]ocuments coming within that [work product] category will not be released without a strong showing of special circumstances, good cause or necessity. The mere hope that such documents might prove useful does not constitute such a showing." Graber Mfg. Co., FTC Dkt. No. 8038 [1965-1967 Transfer Binder] Trade REg. Rep. I 17,409, at 22,614 (1965); accord, R.H. Macy Co., FTG Dkt. No. 8650 [1965-1967 Transfer Binder] Trade REg. REP. If 17,344, at 22,505 (1965). 
Thus, exceptions have been made and production ordered of prehearing conference materials (e.g., the theory of complaint counsel's case, his witnesses and exhibits, and so forth), ${ }^{254}$ statements of government witnesses, ${ }^{255}$ and correspondence with third persons where disclosure is essential to a fair hearing, ${ }^{250}$ but not of information disclosing the FTG's reason for issuing the complaint. ${ }^{257}$ In addition, a hearing examiner has observed that Commission counsel have a duty to disclose any exculpatory material in their files, however developed-but the Commission does not appear to have emphasized this aspect of the rule. ${ }^{258}$ On the other hand, because of its concern with the appearance of fairness as well as fairness itself (since it acts as judge, jury, and prosecutor), the Commission has occasionally ordered disclosure of ex parte communications between the FTG and complaint counsel. ${ }^{259}$

(b) Nonlitigation documents. Respondent's recurrent demands for other information in FTC files has proved more perplexing. In response to the recent amendment of section 3 of the APA, the FTC's rules governing access to its nonlitigation files were rewritten making all data available for public inspection except as specifically exempted. ${ }^{260}$ The exceptions are all-inclusive, however, encompassing (a) records related to internal personnel rules and practices, (b) trade secrets, names of customers, and commercial and financial information which is customarily privileged or was received in confidence, (c) official minutes of FTC meetings, (d) inter-agency and intra-agency memoranda and letters, (e) personnel files, (f) investigatory files compiled for law enforcement purposes except as required to be released in adjudicatory proceedings, and ( $g$ ) other files exempted by statute or executive order. Aside from reversing the prior rules' presumption that all files are confidential, these new rules appear to have made no substantive changes. Release of such documents in adjudicative proceedings, then, is dependent on satisfying the requirements of section 3.36 of the FTC Rules. $^{261}$

254 See authorities cited note I58 supra.

255 See authorities cited note 243 supra.

256 See notes 232 \& 233 supra and accompanying text.

257 See School Services, Inc., FTC Dkt. No. 8729, 3 TRADE REg. REP. If 17,978, 18,064 (1967).

258 Seeburg Corp., FTC Dkt. No. 8682, Certificate of Hearing Examiner to FTC, at 1 (Feb. 3, 1967); see Gellhorn 424 nn.123 et seq., 427 n.141; cf. Canon No. 5, ABA Canons of Ethics.

259 Compare Viviano Macaroni Co., FTC Dkt. No. 8666, 3 Trade REg. REP. I 18,246, at 20,644 (1968), with Texas Co., 60 F.T.C. 1887 (1962).

260 FTC Rules §§ 4.9-.10.

261 See page [72] supra. Nonlitigants may seek such data pursuant to § 4.11 of the FTC Rules by showing "good cause" for its release. 
Just as the thought processes of the agency cannot be probed by the parties, respondent cannot demand file data reflecting the decisionmaking process of the FTC. The policy discussions of the Commission or its officials and employees, as well as the minutes of their meetings and memoranda reflecting such internal decisions, are privileged from disclosure. This "executive privilege" is grounded in the necessity for secrecy to induce candor in the process of consulting and advising FTC officials. ${ }^{202}$

Once again, this privilege of nondisclosure is not unlimited. Ostensibly, the Commission will weigh respondent's need for the documents "against the public interest in preserving the confidentiality of information dealing with internal agency operations."263 In practice, however, this balancing has invariably led to denial of the application for release. To be sure, the Commission sometimes has disclosed internal documents when respondent has challenged the basic fairness of its proceedings, but only when such disclosures revealed the propriety of the FTG's actions. ${ }^{264}$ Where respondent has asserted harassment or discriminatory action, or sought data demonstrating that respondent was arbitrarily selected for enforcement when an entire industry has engaged in the challenged practice, the Commission has turned a deaf

262 With respect to minutes, memoranda, directives, recommendations or other writings of the Commission or any individual Commissioner, these documents relate solely to the Commission's function in reaching a decision. In effect, by requesting these documents, respondent would inquire into the mental processes of the Commission in determining the scope of the orders under investigation. In denying the right to such inquiry, the Supreme Court in the Morgan case has stated that "Such an examination of a judge would be destructive of judicial responsibility. ... Just as a judge cannot be subjected to such a scrutiny, ... so the integrity of the administrative process must be equally respected." In a case involving the National Labor Relations Board, the court had aptly pointed out that if information as to the deliberations of an administrative agency were made public "The function of deciding controversies might soon be overwhelmed by the duty of answering questions about them."

Modern Marketing Service, Inc., FTC Dkt. Nos. 3783, 4589 [1965-1967 Transfer Binder] TrAdE REc. REP. I 17,416, at 22,644-65 (1966), citing United States v. Morgan, 313 U.S. 409 (1941), and NLRB v. Botany Worsted Mills, 106 F.2d 263 (3d Cir. 1939); accord, School Services, Inc., FTC Dkt. No. 8729, 3 Trade REg. REp. If 17,978, 18,064 (1967); Sperry \& Hutchinson Co., FTC Dkt. No. 8671 [1965-1967 Transfer Binder] Trade REg. REP. \ 17,505 (1966); Seeburg Corp., FTC Dkt. No. 8682 (Interlocutory Order Oct. 25, 1966); Graber Mfg. Co., FTC Dkt. No. 8038 [1965-1967 Transfer Binder] Trade Reg. REP. ๆ 17,409, at 22,614 (1965); see Coro, Inc., FTC Dkt. No. 8346 [1963-1965 Transfer Binder] Trade REg. REP. I 16,491, at 21,362 (1963), modified on other grounds, 338 F.2d 149 (Ist Cir. 1964), cert. denied, 380 U.S. 954 (1965).

263 Modern Marketing Service, Inc., FTC Dkt. Nos. 3783, 4589 [1965-1967 Transfer Binder] Trade Reg. ReP. If 17,416, at 22,645 (1966); cf. Davis v. Braswell Motor Freight Lines, Inc., 363 F.2d 600 (5th Cir. 1966); Kaiser Alum. \& Chem. Corp. v. United States, 157 F. Supp. 989 (Ct. Cl. 1958).

264 E.g., L.G. Balfour Co., FTC Dkt. No. 8435 [1965-1967 Transfer Binder] Trade Reg. REP. I 17,347 (1965). See also L.G. Balfour Co. v. FTC, 1964 Trade Cas. I 71,070 (E.D. Va.). 
ear. ${ }^{265}$ If the information sought is likely to support respondent's allegations, these decisions seem questionable. True, the FTG, like other enforcement agencies, has discretion to determine its enforcement program and to select whom it will prosecute. ${ }^{268}$ To allow respondent to challenge this determination at every turn would stall FTG prosecutions. On the other hand, the exercise of this discretion can be challenged if "patently arbitrary and capricious," 267 and, unless respondent is permitted to obtain data in the FTC's files necessary to support its challenge, this "right" becomes meaningless. In addition, the FTC's combined function of prosecutor and trier-of-fact suggests that it should view respondent's demand charitably.

Fairness also demands that the FTC establish specific criteria for the release of file information. ${ }^{268}$ The Commission, for example, might

265 Clearly, an assertion of a difference in treatment alone does not create an issue of the denial of due process.

R.H. Macy \& Co., FTC Dkt. No. 8650 [1965-1967 Transfer Binder] Trade REg. REP. If 17,344, at 22,504 (1965); accord, Coro, Inc. v. FTC, 338 F.2d 149, 152 (1st Gir. 1964), cert. denied, 380 U.S. 954 (1965) (respondent has no "right" to a particular administrative treatment); see Modern Marketing Service, Inc., FTC Dkt. Nos. 3783, 4589 [1965-1967 Transfer Binder] TrADE REG. REP. I 17,416, at 22,645 (1966) (investigational hearing as to respondent's compliance with an FTC order).

266 E.g., Moog Indus., Inc. v. FTC, 355 U.S. 41i, 413 (1958); Moir v. FTC, 12 F.2d 22, 28 (1st Cir. 1926); see First Buckingham Communitÿ, Iñc., FTC Dkt. Nó. 8750, 3 TràdE REG. REP. I 18,357 (1968).

267 FTG v. Universal-Rundle Coxp., 387 U.S. 244, 250 (1967); Moog Indus., Inc. v. FTC, 355 U.S. 411 (1958). See Yick Wo v. Hopkins, 118 U.S. 356 (1886); Jones, Industry-Wide Enforcement, 10 Antrrrusr Bull. 543 (1965); cf. Comment, The Right to Nondiscriminatory Enforcement of State Penal Laws, 61 CoLum. L. RÉv. 1103 (1961).

268 Aside from relying on its "administrative discretion" and that respondent has no "right" to a particular form of administrative treatment, the FTC has provided little guidance. Commissioner Elman, in an eloquent but otherwise only general dissent, argues that the Commission should not stand on privilege.

If, in practical terms, the merits of a claim of bias and prejudice can be ascertained only through intramural inquiry conducted by agency members, this imposes on them an even heavier responsibility. In short, I do not see how agency members can escape the burden-onerous though it be- of satisfying the parties and the public that they have taken a serious charge seriously, and have canvassed the matter in all its ramifications and particulars.

R.H. Macy \& Co., FTG Dkt, No. 8650 [1965-1967 Transfer Binder] Trade REg. REP. I 17,344, at 22,507 (1965) (dissenting opinion). Former Commissioner Reilly's answer to Elman's open-ended approach seems persuasive-although no excuse for a failure to seek a middle ground. He points out that the decision to prosecute is a value judgment based on many factors and a search of agency files probably will not disclose the correctness or constitutionality of that judgment. (On this point Elman agrees, since evidence of bias or prejudice is unlikely to make its appearance in written records.) Even more damaging is the ease with which respondents could disrupt FTC enforcement proceedings.

If a mere ipse dixit assertion of partiality with limited knowledge such as that available to respondent is sufficient to require an inquisition into the processes whereby the Commissioners arrived at one result rather than another, the formula for completely frustrating Commission effectiveness is clear.

Id. at 22,510 (separate statement of Commissioner Reilly). On the other hand, respondent is unlikely to have concrete evidence of any unfair procedures without examining the 
advise respondent that release will depend upon whether (1) respondent has sought to delay or expedite trial of the case; (2) respondent's charge goes to the fairness of the proceeding, of the prosecution, or of the scope of the order (if the latter, the inquiry could be delayed until a finding against respondent is made); (3) respondent has, if possible, substantiated its allegation to indicate the likelihood that such evidence exists; (4) granting respondent's request will substantially delay the proceeding. Free and open staff discussion does not confer a license to conceal embarrassing information.

Less troublesome are FTC decisions refusing to reveal the basis for the Commission's "reason to believe" that respondent is violating the law: ${ }^{269}$ such information as supports the complaint will be disclosed in pretrial discovery and during the hearing. Requests for file information should not become a substitute for the adjudicative process. Nor should FTC files be opened to determine the basis of the Commission's earlier closing of the same or similar proceedings. ${ }^{270}$ Past decisions and staff interpretations of FTC policies need not govern current interpretations, although at some point the question of even-handed enforcement will recur. ${ }^{271}$ The same reasoning holds for refusals to disclose staff and FTG discussions of consent negotiations among themselves or with respondent $\mathrm{t}^{272}$ or compliance reports submitted by it and other respondents. ${ }^{273}$ Refusal in these cases may also be buttressed by the familiar justification of avoiding mischievous contentiousness which seeks ir-

Commission's files. See Statesman Life Ins. Co., FTC Dkt. No. 8686 [1965-1967 Transfer Binder] Trade REg. REP. If 17,790, at 23,148-9 (1966) (Elman dissenting).

269 E.g., School Services, Inc., FTC Dkt. No. 8682, 3 Trade REg. REP. $\$$ (17 17,978, 18,064 (1967); Shell Oil Co., 62 F.T.C. 1488, 1491 (1963).

270 E.g., Statesman Life Ins. Co., FTC Dkt. No. 8686 [1965-1967 Transfer Binder] TrADE REg. REP. I 17,790 (1966); United Biscuit Co. of America, 62 F.T.C. 1536 (1963). However, such information may be relevant when fashioning the Commission's order.

271 Double Eagle Lubricants, Inc. y. FTC, 360 F.2d 268 (10th Cir. 1965); P. Lorillard Co. y. FTC, 186 F.2d 52, 55-6 (4th Cir. 1950); Statesman Life Ins. Co., FTC Dkt. No. 8686 [1965-1967 Transfer Binder] Trade REg. REP. I 17,790 (1966); Texas Co., 60 F.T.C. 1887 (1962); Postal Life \& Cas. Ins. Co., 52 F.T.C. 651 (1956).

272 E.g., William H. Rorer, Inc., FTC Dkt. No. 8599 [1963-1965 Transfer Binder] TRADE Reg. Rep. I 16,804 (1964), appeal dismissed, BNA ANTtTrust \& TrADE Reg. Rep. No. 151, A-7 (June 2, 1964); Seeburg Corp, FTC Dkt. No. 8682 [1965-1967 Transfer Binder] TradE REG. REP. I 17,729, at 23,055-6 (1966). Further, as the hearing examiner noted in Seeburg, "the requested production of documents relating to the disposition of settled cases . . . would be inappropriate and irrelevant since they are not reflective of the Commission's policy but rather [are] a disposition based on the availability of the evidence in a particular case and a conservation of time in obtaining relief in the public interest." Hearing Examiner's Certificate to the FTC, at 11-12, filed Oct. 3, 1966.

273 E.g., Modern Marketing Service, Inc., FTC Dkt. Nos. 3783, 4589 [1965-1967 Transfer Binder] Trade Reg. ReP. I 17,416, at 26,644 (1966); Standard Motor Prods., Inc., FTC Dkt. No. 5721 [1963-1965 Transfer Binder] TRADE REg. Rep. I 16,860 (1964); Dayton Rubber Co., 62 F.T.C. 1519 (1963). 
relevant data, of preserving freedom for staff and agency action and consultation, and, at the same time, of maintaining both fairness and all its appearances. In general, it is difficult to fault the Commission's performance here.

Not so satisfactory, however, is the Commission's refusal to release internal studies prepared by its staff experts or to permit discovery of its experts' opinions. In $S$ \& $H^{274}$ the FTC ruled that a report prepared by its economic staff was not discoverable before trial. Respondent sought not only the economic study prepared by the FTC's Bureau of Economics, but also the underlying data which formed the basis for the Bureau's study, including all communications received from retailers and trading stamp exchanges and companies. In refusing discovery, the Commission relied on the sensitive nature of the data and argued that much of it came within the work product category. Good cause for its release was said not to have been shown since if, as respondent asserted, complaint counsel intended to present an expert witness or to rely on the staff study, the examiner's prehearing order would permit discovery (including the underlying data) "in ample time to prepare its defense."275

This argument misconceives the purpose of discovery.

Mutual knowledge of all the relevant facts gathered by both parties is essential to proper litigation. To that end either party may compel the other to disgorge whatever facts he has in his possession. ${ }^{276}$

Under the Commission's one-sided approach, however, information acquired by its experts is available to respondent only if harmful to him-in which case, of course, he will have no need for it. Certainly the work product doctrine should not be extended to cover expert

274 Sperry \&: Hutchinson Co., FTC Dkt. No. 8671 [1965-1967 Transfer Binder] TradE REG. ReP. II 17,505 (1966).

275 Id. at 22,779. The FTC also rejected, as unsupported, respondent's convenience argument-that it otherwise faced the practical difficulty of investigating activities of 70,000 retail licensees and 400 trading stamp companies-and its contention that disclosure would expedite the trial. The Commission concluded, however, that, "as the phrasing of its request indicates, it is asking for general access to the Commission's confidential investigational files merely to see whether something useful to its defense may turn up." Id. at 22,780 .

276 Hickman v. Taylor, 329 U.S. 495,507 (1947). In considering the Commission's ruling in $S \& H$, it should be noted that FTC discovery rules were not extended to include "pure discovery" until 1967, a year after $S \& H$ was decided. But the current rules would seem to require this analysis. In any case, the factual data of the Commission's economic study as well as the expert's conclusions therefrom fit within the scope of the Supreme Court's definition. See also Annots., 88 A.L.R.2d 1186 (1963), 86 A.L.R.2d 138 (1962), 77 A.L.R.2d 1182 (1961). 
information which it normally would not protect. ${ }^{277}$ Nor would the fairness view of some courts in civil litigation-" that it is unfair for one party, without expense, to obtain information from an expert who has been hired by the opposing party for an agreed compensation"278_-seem applicable to administrative proceedings, especially where the staff study may not be litigation-inspired. Moreover, as Commissioner Elman has pointed out, this policy of secrecy is

inconsistent with a fundamental and paramount function of the Commission. One of the main purposes for which this agency was established was to conduct economic inquiries of the kind which that report reflects, and to make the results of such inquiries available to the public. ${ }^{279}$

He also refuted the FTC staff argument that production of the report would interfere with the free flow of information between the Commission and its staff:

The Division's staff consists of professional economists whose obligation is to report data objectively and impartially, letting the chips fall where they may ... . To justify confidentiality on the ground that our economists would not otherwise feel free to submit such factual and impartial reports is to demean their professional status. To keep a report confidential because it conflicts with a position being taken by the Bureau of Restraint of Trade in an adjudicative proceeding would be clearly arbitrary ... [and] would violate the fundamental principle of justice and fairness which prohibits a Government agency from suppressing documents which may be critical to a respondent in making his defense. ${ }^{280}$

Other decisions suggesting that Commission experts cannot be subpoenaed to analyze technical facts seem equally defective and contrary to the purpose of an administrative agency as a repository of expert information. ${ }^{281}$

277 Friedenthal, Discovery and Use of an Adverse Party's Expert Information, 14 STAN. L. REv. 455, 488 (1962). Although not asserted by the FTC, some courts have refused disclosure of expert opinion under the attorney-client privilege; this too seems unsound. Id. at 455-69.

278 Id. at 479.

279 Sperry \& Hutchinson Co., FTC Dkt. No. 8671 [1965-1967 Transfer Binder] TRADE Rxc. REP. I 17,505, at 22,780 (1966) (dissenting opinion).

280 Id.

281 See Humble Oil \& Refining Co., FTC Dkt. No. 8544 (Interlocutory Order Dec. 5, 1963); Standard Motor Prods., Inc., FTC Dkt. No. 5721 [1963-1965 Transfer Binder] TRADE REG. REP. I 16,860 (1964); Thomasville Chair Co., 56 F.T.C. 1651 (1959). See also K.C. Davis, Administrative Law Treatise \& 11.08 (1958). However, in Standard Motor and 


\section{Discovery by Respondent from Third Persons}

As FTC discovery process available to respondent has been extended to include not only evidence essential for its case but also information merely helpful to its defense or rebuttal, the Commission similarly has expanded respondent's ability to acquire sensitive information held by third parties. This authorization has been further necessitated by FTC adoption of the continuous hearing rule and its policy of restricting disclosure of private information in its files to that which is not available from third parties. Under current rules, then, respondent may apply to the examiner, in ex parte hearings, for documentary evidence from third persons for the purpose of discovery, for obtaining evidence, or for both purposes. ${ }^{282}$ Depositions are slightly more restricted. The examiner has broad discretion to order such third persons to disclose information to respondent as requested without regard to its sensitive character. ${ }^{283}$

Since respondent is under no duty to hold such information confidential-although sound trial tactics and insuring witness cooperation may suggest that it do so-and, in the case of depositions, such information may be public when filed, ${ }^{284}$ third parties often refuse to cooperate without Commission or judicially compelled assurances of nondisclosure. At one time this assurance was obtained by refusing to disclose the data without court enforcement of the FTG subpoena, at which time the court would condition its order on a requirement of confidential treatment enforceable by its contempt powers. ${ }^{285}$ But the

Thomasuille Chair the Commission also concluded that the evidence sought by respondent was not relevant to the issues in the case.

282 FTC Rules $\$ 3.34$. Prior to the May I, 1968, revision, this rule did not clearly cover production from nonparties; but shortly after the Commission so read the earlier rule, it was revised to include nonparties specifically. See Lehigh Portland Cement Co., FTC Dkt. No. 8680, 3 Trade REc. REP. 18,265 (1968). As to the ex parte nature of the subpoena application, see $i d$. at $\ \uparrow 18,185,18,322$ (1968). On the other hand, the FTC will not make available to respondent its broad investigative powers such as the power to compel \& 6(b) reports. E.g., American Brake Shoe Co., FTC Dkt. No. 8622 [1965-1967 Transfer Binder] Trade REc. ReP. ๆ 17,256 (1965) (citing cases).

283 See, e.g., Associated Merchandising Corp., FTC Dkt. No. 8651, 3 TrAde REg. REP. If 18,018, 18,053 (1967); Lehigh Portland Cement Co., FTC Dkt. No. 8680, 3 Trade REc. REP. If 18,265 (1968); Crown Cork \& Seal Co., FTC Dkt. No. 8687 (Interlocutory Order Jan. 13, 1967). See also Associated Merchandising Corp., FTC Dkt. No. 8651, 3 TrADE REC. REP. If 17,935 (1967). Complaint counsel also have been warned not to advise third persons not to cooperate with respondent's attorney in connection with confidential data sought by respondent. See Best \& Co., FTC Dkt. No. 8669 [1965-1967 Transfer Binder] TradE REg. REP. I 17,585, at 22,852 (1966); see also id. (Jan. 13, 1967); Lenox, Inc., FTC Dkt. No. 8718, 3 Trade Reg. REP. I 18,324, at 20,693 (1968).

284 See supra note 164.

285 E.g., FṬ v. Bowmạn, 149 F. Supp. 624 (N.D. Ill.), aff'd, 248 F.2d 456 (7th Cir. 1957). 
Supreme Court has indicated that this procedure is inappropriate, at least until the witness has produced the documents and the agency has had an opportunity to rule on the witness's request with the sensitive information before it. ${ }^{280}$ Thus, under the current rules, third parties who wish to protect the information they are asked to disclose to respondent, from either public dissemination or their respondent-competitor's eyes, must seek a protective order first from the examiner. The examiner, then, is to weigh this request in the same manner in which he determines whether continued confidential treatment is warranted for private information from FTG files released to respondent. ${ }^{287}$ (It should be noted, however, that the only question is whether that data is so sensitive as to warrant protective treatment; sensitivity cannot justify nondisclosure.) If either party is dissatisfied with the examiner's ruling, it may appeal to the Commission. But the FTC will affirm the examiner's order unless it is shown that he has abused his discretion. ${ }^{288}$ Finally, if the Commission refuses to order confidential treatment, judicial protection to prevent irreparable injury which cannot await a final decision in the proceeding is available in the district courts. ${ }^{289}$

This procedure seems eminently sensible. One can only wonder, however, why it took the Commission and the courts so long to adopt it.

\section{SOME OBSERVATIONS AND REcommendations}

This study has examined the bases, objectives, and implementation of FTG confidentiality policies at the investigative, pretrial, and hearing stage. Without repeating specific questions, comments, and sug-

286 FCC v. Schreiber, 381 U.S. 279 (1965).

287 Koppers Co., FTC Dkt. No. 8755 (Interlocutory Order Aug. 14, 1968); id. (July 2, 1968); id. (Hearing Examiner Order July 9, 1968); Mississippi River Fuel Corp., FTC Dkt. No. 8657 (Interlocutory Order June 8, 1966), reconsideration denied, [1965-1967 Transfer Binder] TrAde REG. REP. I 17,612 (1966); National Dairy Prods. Corp., FTG Dkt. No. 8548 [1963-1965 Transfer Binder] TRADE REG. Rep. I 16,778 (1964); see supra notes 160, $240-2$ and accompanying text. For procedures of an earlier day, see Columbus Coated Fabrics Corp., 54 F.T.C. 1888 (1957).

288 See authorities cited note 287 supra; Koppers Co., FTC Dkt. No. 8755, 3 TrAdE REG. REP. I 18,329 (1968); $i d$. (Interlocutory Order Denying Appeal July 2, 1968) (this is one of three orders and opinions issued in this case on this date by the FTC); Crown Cork \& Seal Co., FTC Dkt. No. 8687 [1965-1967 Transfer Binder] TradE REg. REP. If 17,828, at 23,201 (1967); id. (Interlocutory Orders March 3 \& April 10, 1967).

280 See FCG v. Schreiber, 381 U.S. 279 (1965); Sperry \& Hutchinson Co. v. FTC, 256 F. Supp. 136 (S.D.N.Y. 1966); R.H. Macy \& Co. v. Tinley, 249 F. Supp. 778, 782 (D.D.C. 1965). Some courts have not yet perceived the message of Schreiber and continue to condition subpoena enforcement on assurances of confidential treatment. E.g., FTC v. Continental Can Co., 267 F. Supp. 713 (S.D.N.Y. 1967) (the final chapter to the production sought by respondent in Crown, supra note 288); cf. note 52 supra. This seems clearly erroneous. 
gestions offered at various stages of this analysis, several observations should be made. ${ }^{290}$

The primary impression one obtains in examining scores of FTC discovery cases involving questions of confidentiality (most of them decided during the past decade) is that they are incredibly repetitive, and their analysis is often limited to a few simple points. For example, at least a dozen opinions state that FTC files will not be made available to respondent without a showing (a) of "real and actual need" and (b) of the unavailability of the documents elsewhere. But the first standard does not suggest to respondent what it must show to demonstrate that the file information should be made available, and the second requirement is inconsistent with the Commission's own discovery rules. In other words, the Commission's confidentiality decisions (and rules) have been needlessly vague and their applications often unjustified or inconsistent. Constant alteration of confidentiality procedures and FTC rules has contributed to the resulting confusion of examiners and counsel. To be sure, some standards can be derived from the cases, but here the unavailability of procedural decisions or of a usable current index has prevented general understanding. Nor have the parties sought to aid the Commission by suggesting rational alternatives. Commission and respondent's counsel, instead, have sought to score argumentative points or, it seems, to create confusion by constant and redundant appeals. Unconscionable delay, the obvious objective of some, has been the result.

But even if this study contributes to the development of sound policy, specific standards, or rational applications, there will continue to be a need for more explicit rules and for streamlining the Commission's method of deciding confidentiality questions prior to the final decision on the merits.

Obviously some delay is inherent in an adversary system where large sums may be involved or critical data central to the future of a business

280 Despite the length of these two articles, they do not canvass all problems of confidentiality raised by FTC pretrial and adjudicative practices. For example, what of discovery by private litigants in a nonagency action who seek to discover materials from FTC files? The Commission has indicated in dicta that one reason for public disclosure of adjudicative hearings is to foster rather than discourage treble damage clamaints. See, e.g., Carvel Corp., FTC Dkt. No. 8574 [1963-1965 Transfer Binder] Trade Reg. Rep. If 17,128 (1964). But private discovery in a civil action is subject to a claim of executive privilege. See Broussard v. Socony Mobil Oil Co., 350 F.2d 346, 352-3 (5th Cir. 1965). Likewise, Congressional requests for information, whether or not confidential, have not been considered here. Cf. Pillsbury Co. v. FTC, 354 F.2d 952 (5th Cir. 1966); Note, Administrative Law: Congressional Criticism of FTC for Decision in Pending Case Held to Deprive Administrative Litigant of Due Process, 1966 Duke L.J. 779. Nor have requests for confidential documents by the FTC from state agencies. See, e.g., Foremost Dairies, Inc., 55 F.T.C. 2063 (1959). 
are at stake. But the current impasse of repetitive interlocutory appeals to the Commission, sometimes of virtually identical confidentiality issues in the same proceeding, is neither inevitable nor insoluble. One might wish that counsel would be less contentious or more selective, but that seems a vain and idle dream. Thus, rethinking of current appellate procedures and experimentation with alternative approaches seems warranted.

Current FTC provisions for review of an examiner's interlocutory confidentiality rulings follow two routes in addition to the usual review available when his initial decision on the merits is rendered. If the question involves release of FTC files, the examiner's decision, whether for or against disclosure and with or without protective treatment, can be appealed to the full Commission and apparently is automatically reviewed. ${ }^{291}$ Or, the Commission may on its own motion review the examiner's decision on the release of its files. ${ }^{292}$ But if the examiner's ruling concerns the disclosure of confidential data directly from respondents' or other private sources, an appeal

will be entertained by the Commission only upon a showing that the ruling complained of involves substantial rights and will materially affect the final decision, and that a determination of its correctness before conclusion of the hearing is essential to serve the interests of justice. ${ }^{283}$

Despite numerous changes in these provisions over the past five years, the essential test for review has remained unchanged. In actual practice, appeals of confidentiality decisions are either granted as a matter of course or decided by an opinion holding that a sufficient showing for appeal has not been made. The heavy burden on the Commission of hearing and deciding procedural cases seems intolerable; it appears to have contributed to the FTC's reliance on general statements and inadequate opinions.

The Administrative Conference has recommended amendment of section 8 of the APA to permit agencies greater flexibility in reviewing an examiner's initial decisions. ${ }^{294}$ After reviewing this recommendation and other alternatives, Professor Auerbach concluded that the administrative agencies should be permitted "to experiment with different ways of delegating the decision-making function and [of] reviewing the

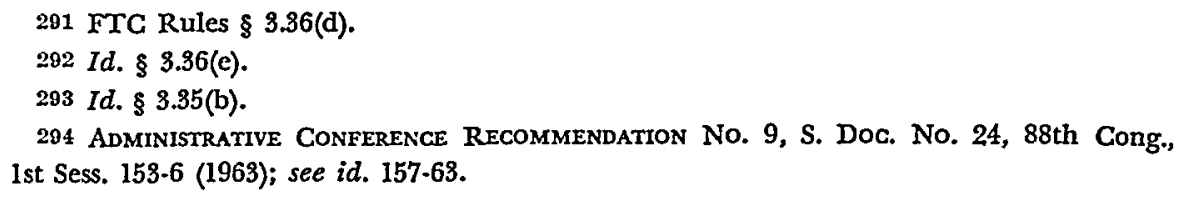


decisions of their delegates,"205 the hearing examiners. While those studies concentrated on review of an examiner's final decision, the lessons of this study suggest their applicability to review of FTC procedural decisions.

In an attempt to meet the need for consistent confidentiality rulings, for the development of rational standards of disclosure and protective treatment of sensitive data regardless of whose data it is or where it is located, and for expediting final decisions on procedural rulings, several recommendations can be made. First, the FTC's new rules authorizing hearing examiners to make the initial determination of all confidentiality questions clearly seem to be an important step in the right direction. It should not be reversed. Second, an automatic right to appeal by either party to the Director of Hearing Examiners should be allowed; in addition, the Director should be authorized to review an examiner's decision on his own motion, when it appears inconsistent with Commission policy, if neither party seeks review. (Such review should not interrupt the discovery process or trial of the matter unless specified by the Director.) Unless the Director's decision reverses the examiner's ruling or modifies it so as to constitute an effective reversal, appeal to the Commission should not be granted routinely except when the Director certifies the matter as involving a significant question not previously ruled upon by the Commission. Third, one Commissioner should be designated to oversee such (and perhaps other) procedural rulings and to hear appeals where the Director reverses the examiner or when he has certified the question. This decision by one Commissioner-authorized by the 1961 Reorganization Plan ${ }^{296}$ should be final, except, perhaps, in the unusual situation where his decision would conflict with FTG Rules which, in his opinion, need change. ${ }^{297}$ In the latter case, review by the full Commission should be available on certification of the question by the "procedure" Commissioner to the full Commission.

While adding additional appeal steps for deciding novel questions, this suggested structural change in the appeal route has the merit of

295 Auerbach, Scope of Authority of Federal Administrative Agencies to Delegate Decision Making to Hearing Examiners, 48 MINN. L. REv. 823, 866 (1964). See also Note, Intermediate Appellate Review Boards for Administrative Agencies, 81 HARv. L. Ruv. 1325 (1968); Long, The Proposed New Administrative Procedure Act, 55 GEo. L.J. 761, 771 (1967).

296 Reorganization Plan No. 4 of 1961, 26 Fed. Reg. 6191 (1961). The Commission has made only sparing use of this authority. See Delegation of Functions, 27 Fed. Reg. 481-2 (1962); Auerbach, The Federal Trade Commission: Internal Organization and Procedure, 48 MinN. L. REv. 383, 417 (1964).

297 of course, interlocutory judicial review in the federal district courts would be available to prevent irreparable injury. See notes 288 \& 289 supra and accompanying text. 
assuring consistent application (as far as an institutional structure can) of FTG confidentiality policies at the discovery and trial level and of deciding most questions below the "full" Commission level. Both the Director and single Commissioner would develop sufficient knowledge and expertise in these difficult questions to allow more thoughtful and careful exploration of the ramifications of their decisions; hopefully, it also would permit experimentation with alternative approaches. In addition, it would free other Commissioners to concentrate on more significant policy issues and to meet criticism of the FTG's enforcement planning. On the other hand, this suggestion need not be instituted wholesale. Individual changes could be tried piecemeal and extended only as shown to be workable. Nor is it the only way in which to accomplish these ends. But it does seem clear that further experimentation with current appeals procedure is required. Finally, no structural modification can eliminate the need for general publication of all FTC procedural decisions and for the development of a current index available to practitioner and examiner alike. 298

Although one must hesitate before recommending still another change in the FTC Rules, nevertheless, this study has shown that clearer standards could be set forth in the Rules and that inconsistent provisions such as the unavailability requirement in section 3.36 need to be eliminated. Further, Cohn and Zuckman have presented a cogent case for adding specific Rule directions that in camera procedures be required until any decision is made as to whether protective treatment

298 The reforms suggested here actually would not significantly vary the formal structure currently applied by the Commission to interlocutory appeals. For at least the past five years Commissioner MacIntyre has been designated the "motions" commissioner to whom all interlocutory appeals are presented for review and decision. He apparently has full power, delegated by the chairman, to decide such appeals in the name of the Commission. Interview with John V. Buffington, Assistant to FTC Chairman Dixon, July 29, 1968. However, except for the most routine requests for time extensions, Commissioner MacIntyre has declined to exercise his authority and has instead referred all questions which might raise controversy to the full Commission. For this reason several FTC staff members have candidly questioned the feasibility of the proposals offered here; FTC practitioners and academic observers have been more optimistic.

Perhaps this staff skepticism is justified. On the other hand, it also reinforces the point that structural reforms will not, by themselves, correct procedural abuses. Inordinate appeals, interminable delays, and inconsistent or irrational rules and decisions are neither inevitable nor incurable, but they will not be eliminated until some agreement is reached as to the aims and implementation of FTC procedures. Cf. Suburban Propane Gas Corp., FTC Dkt. No. 8672 (Interlocutory Order June 3, 1968). Federal courts facing similar problems have surmounted most of them, and the Commission's current willingness to listen to suggested changes, to be receptive to reason, and to experiment with procedural reforms (as illustrated by Rules' development) belies staff pessimism and renders their doubts unpersuasive. See, e.g., Lehigh Portland Cement Co., FTC Dkt. No. 8680, 3 TRADE REg. REP. đ 18,475 (1968); Koppers Co., FTC Dkt. No. 8755, 3 Trade REg. REP. I 18,577 (Interlocutory Order, Nov. 1, 1968). 
of sensitive data is warranted. ${ }^{299}$ But before another revision is attempted, the Commission should consider adopting a different method of drafting its rules. At present, revisions are accomplished within the agency and in secret session. ${ }^{300}$ Comments of FTC practitioners, scholars or others are not solicited. Nor are any interpretations or "notes" such as utilized in the revision of federal and state court rules provided. All these suggestions should be considered and, if feasible, a joint staff-practitioner-academic committee established to rewrite and recommend FTC practice rules. The final decision, of course, would still be the Commission's.

\footnotetext{
299 Cohn \& Zuckman, FCC v. Schreiber: In Camera and the Administrative Agency, 56 GEo. L.J. 451 (1968).

300 Preparation of the FTC's [July 1] 1967 rule revisions was assigned to a sevenman committee drawn from the Commission's top-level staff. Its chairman was John V. Buffington, assistant to the Chairman of the Commission, and its other members were the six bureau chiefs. Inquiries concerning the preparation of the rules elicit the response that no further information will be released concerning the committee, its recommendations to the Commission, or changes, if any, made by the Commission itself in the committee's proposals. However, it is known that subordinate bureau staff members did much of the actual drafting of the proposals submitted by the committee.
}

BNA Antitrust \& Trade Reg. Rep. No. 321, B-1 (Sept. 5, 1967). 